\title{
On the preferences of CoCo bond buyers and sellers
}

\author{
Guglielmo Maria Caporale*, Woo-Young Kang
}

Department of Economics and Finance, Brunel University London, UK

\section{A R T I C L E I N F O}

\section{Article history:}

Received 12 August 2020

Accepted 9 February 2021

Available online 3 March 2021

\section{JEL classification:}

C25

C39

F39

G11

G21

G24

G28

\section{Keywords:}

CoCo bonds

Buyers and sellers

Preference scores

Multinomial logistic regressions

\begin{abstract}
A B S T R A C T
This paper analyses the preferences of CoCo bond buyers and sellers assuming that they are mutually exclusive, and that buyers prefer CoCo bonds with higher safety-adjusted returns. We take into account both bond and issuing banks' characteristics and investigate differences in the responses of investors in the low (25th), medium (50th) and high (75th) percentiles based on safety-adjusted returns. We find that CoCo bond buyers in those percentiles can be characterised as growth, value and active investors, respectively. In the case of sellers their needs to have bankruptcy protection and to comply with the Basel III financial regulations play a more important role than the buyers' desire to increase their income from this fixed-income instrument. Sellers prefer to issue CoCo bonds when they are not financially sound whilst buyers have a preference for CoCo bonds with low risk; therefore, they can be characterised as being risk-loving and risk-averse respectively. Globally, the strongest preference responses of buyers and sellers are found in the UK and China, and those in the 75th percentile (with the highest safety-adjusted returns) react to the widest set of CoCo bond and issuing bank's factors.
\end{abstract}

(C) 2021 The Author(s). Published by Elsevier B.V. This is an open access article under the CC BY license (http://creativecommons.org/licenses/by/4.0/).

\section{Introduction}

A contingent convertible ( $\mathrm{CoCo}$ ) bond is a fixed-income security that provides coupon payments to investors until it is converted into equity or suffers a write-down of its face value when the bank's capital level falls below a predetermined lower trigger threshold (De Spiegeleer et al., 2014). CoCo bonds have recently become one of the most commonly used financial instruments for satisfying the more stringent financial regulations imposed by the Bank of International Settlements (BIS) and for protecting banks from insolvency. Consequently, CoCo bond issuance has been steadily increasing, with banks issuing \$450 billion in CoCo bonds globally from January 2009 to September 2015. In addition, the European Central Bank's October 2014 asset quality review (AQR) reported that CoCo bonds accounted for 32 billion Euros of the total of 92 billion Euros in new security issues from July 2013 to August 2014 (Avdjiev et al., 2015).

CoCo bonds add flexibility to the capital structure of banks. Since they are typically treated as debt, they allow banks to take advantage of the benefits of debt financing. Then, when capital falls below the lower trigger threshold during a crisis period, banks can quickly, easily and effectively convert these bonds into equity or write down their principles (Raviv, 2004; Flannery, 2005, 2016; Squam Lake Working Group, 2009; McDonald, 2013; Pennacchi et al., 2014; Avdjiev et al., 2015); thus, CoCo bonds act as automatic bankruptcy protection devices. Regulators have advocated the use of CoCo bonds because they absorb losses without using taxpayers' money (De Spiegeleer et al., 2014). In addition, they represent

\footnotetext{
* Corresponding author at: Department of Economics and Finance, Brunel University London, Uxbridge UB8 3PH, UK.

E-mail addresses: Guglielmo-Maria.Caporale@brunel.ac.uk (G.M. Caporale), woo-young.kang@brunel.ac.uk (W.-Y. Kang).
} 
Additional Tier 1 (AT1) or Tier 2 (T2) capital for banks to meet the Basel III requirements. For all these reasons, banks are increasingly issuing CoCo bonds.

However, their high coupon rate is a disadvantage for the issuing firm; also, the loss-absorbing capacity of Coco bonds is insufficient (Admati et al., 2013; Avdjiev et al., 2015), they suffer from pricing complexities, a high correlation with systematic economic events (Avdjiev et al., 2015) and potential shareholder dilution. Therefore, it is important to understand how equity markets react to the issuance of $\mathrm{CoCo}$ bonds and the role played by their characteristics and those of the issuing banks.

To date there have only been a few market analyses based on CoCo bond issuance, most of them being event studies focusing on general equity investors. This paper examines instead the preferences of CoCo bond investors (buyers) and issuers (sellers) between 1 April 2010 and 18 December 2019. We assume that buyers prefer CoCo bonds with a higher safety-adjusted return measured by the CoCo bond yield-to-call (or yield-to-maturity) multiplied by the spread of common equity tier 1 ratio on the CoCo bond's trigger level which represent the return and safety (i.e., the safety-adjusted return) of CoCo bonds, respectively. We find that the buyers, in contrast to sellers, prefer to have CoCo bonds with a high return-to-risk, a low trigger level (to avoid conversion which forces them to internalise the losses) and a small amount issued (to prevent diluting the current shareholders' ownerships). Buyers also prefer CoCo bonds to be issued by banks which are large sized and have low default and credit risk but high profitability. On the contrary, sellers prefer to issue CoCo bonds mainly to prevent bankruptcies and satisfy financial regulations. Therefore, they prefer to issue CoCo bonds in larger amounts, especially when they are not financially sound and have a higher default risk, and are inclined to provide lower coupon payment to investors.

We extend our analysis to obtain stratified preference scores by estimating multinomial logistic regressions and define buyers as having a preference for CoCo bonds if their safety-adjusted return is higher than the corresponding low (25th), medium (50th) and high (75th) annual percentile values (note that the preferences of buyers and sellers are assumed to be mutually exclusive). By running multinomial logistic regressions, we derive conditional probability measures to estimate the partial impact of a marginal change in the CoCo bond and issuing bank's characteristics on the probability of having CoCo bonds with low, medium and high safety-adjusted returns.

We find that CoCo buyers in the low percentile act as growth investors who are mostly sensitive to the coupon payments they receive. By contrast, the medium percentile CoCo bond buyers are value investors who prefer long-term investments in CoCo bonds with perpetual maturity. Finally, CoCo bond buyers in the high percentile are active investors who monitor most CoCo bonds' and their issuing bank's characteristics as well as the underlying economic situation. As for sellers, we find that their preferences are stronger; they mostly consider CoCo bonds as a bankruptcy protection device for the issuing banks which also comply with the Basel III regulations, whilst buyers tend to focus on their need to invest and increase their financial wealth. Sellers prefer to issue CoCo bonds in a situation of financial distress whilst buyers prefer CoCo bonds when the financial outlook is sound; therefore, their respective behaviours can be characterised as riskloving and risk-averse.

We then examine the preferences of global buyers and sellers across the world by considering the country-specific CoCo bond market concentration (the inverse of the Herfindahl index) and assuming that a stronger degree of CoCo bond market competition implies a stronger response of preferences to their determinants. We find that responses are significant in the main European countries, Brazil, Mexico and a few of the main Far East countries, and strongest in the UK and China. Further, investors in the 75th percentile (with the highest safety-adjusted returns) are those affected by the largest number of factors.

The layout of the paper is the following: Section 2 reviews the relevant literature; Section 3 develops the hypotheses of interest; Section 4 outlines the methodology; Section 5 describes the data and presents the empirical findings; Section 6 offers some concluding remarks.

\section{Literature review}

The extant literature on CoCo bonds is limited, but rapidly expanding. It includes four main strands analysing CoCo bond developments, properties, design and effects on firms and investors. The first discusses previous versions that highly resemble CoCo bonds. Flannery (2005) proposed a reverse convertible debenture (RCD) that automatically converts into common equity when the market capital ratio falls below a certain threshold, which is determined by the current share price. His work provides critical insights into market triggers as a mandatory conversion method, using stock prices as a tool for conversion from bond to equity. Flannery (2016) proposed a contingent capital certificate that also uses the market trigger to convert debt into equity.

Raviv (2004) introduced a debt-for-equity swap (DES) contract that pays its holder a fixed payment upon maturity unless the bank's asset falls below a certain pre-determined conversion threshold; otherwise, it converts into common equity. Squam Lake Working Group (2009) suggested a regulatory hybrid security type that remains long-term debt during normal periods and converts into equity when both financial markets and the issuing bank suffer financial distress. Glasserman and Nouri (2012) proposed a contingent capital type with a capital-ratio trigger with partial and ongoing conversion. The capital ratio is based on accounting or book values designed to approximate regulatory capital requirements. The partial and ongoing conversion process enables firms to convert just enough debt into equity to meet the regulatory capital requirements each time the capital ratio falls below the minimum threshold. Finally, Pennacchi et al. (2014) suggested the call option-enhanced reverse convertible (COERC) approach, which resembles a CoCo bond except that shareholders have the option to buy back converted shares from COERC investors at the bonds' par values. 
Subsequently, Albul et al. (2013) presented the formal model for CoCo bonds, which started the discussion about their properties. They maintained that CoCo bonds provide most tax benefits as a straight debt, while offering the same protection as equity. This protection increases as the bond's conversion trigger level increases. The Squam Lake Group (Baily et al., 2013) stressed that financial authorities should encourage banks to issue CoCo bonds. In the Bank for International Settlements' (BIS) Quarterly Review, Avdjiev et al. (2013) provided an official explanation of CoCo bonds. They emphasized the importance of the trigger level (mechanical or discretionary) and the loss-absorbing mechanism (conversion to equity or principal write down).

As for research on the design of CoCo bonds, Pennacchi (2010) argued that early conversion during financial distress minimizes the default risk at a lower cost. Himmelberg and Tsyplakov (2012) found that the principal write-down conversion method generates incentives for banks to have high leverage, increasing the cost of financial distress and the cost of capital compared to the equity conversion method. Koziol and Lawrenz (2012) suggested using other devices together with CoCo bonds to control risk-shifting incentives to prevent manipulations of the bonds' risk control technologies and/or contracts. Calomiris and Herring (2013) argued instead that banks should hold significant quantities of CoCo bonds and use market value triggers with 90-day moving average equity market values. Davis et al. (2014) tested hypothetical CoCo bond data under three different trigger regime scenarios: a fixed-trigger regime, a regulator regime and a prediction-market regime. They concluded that CoCo bonds have fewer conversion errors and are less subject to manipulation under fixed-trigger and prediction-market regimes than under regulator regimes. McDonald (2013) suggested that CoCo bonds should use a dual trigger incorporating the firm's stock price and the financial institution's index as the determinants for its threshold. This approach considers simultaneously both micro and macro financial conditions. As another enhancement, Corcuera et al. (2014) proposed a coupon cancellable contingent capital (Coca $\mathrm{CoCo}$ ) bond, which cancels its coupon when a pre-defined barrier higher than the conversion barrier is broken through. This discourages speculative short-selling activities and significantly reduces the death spiral effect. Hilscher and Raviv (2014) argued that there is a conversion point at which shareholders become indifferent towards risk-taking.

Yang and Zhao (2017) introduced contingent capital, a contingent convertible security (CCS) that repeatedly converts between debt and equity depending on the firm's financial situation: that is, if the firm falls into (recovers from) recession, it converts from debt (equity) to equity (debt). Yang and Zhao (2015) enhanced this CCS by incorporating an asset jump risk. This new type of CCS dynamically adjusts the firm's capital structure without incurring adjustment costs and does not suffer from debt overhang or risk-shifting incentive problems. Sundaresan and Wang (2015) proved that using market triggers is inappropriate because such triggers involve price uncertainty, market manipulation, inefficient capital allocation and frequent conversion errors with no unique equilibrium. Thus, regulators reacting to market prices may not gain the financial information they need, since their interventions themselves may affect firms' security prices (Birchler and Facchinetti, 2007; Bond et al., 2010; Davis et al., 2011).

Chen et al. (2013) investigated the effects of CoCo bonds. They argued that they benefit the issuing firm if the conversion trigger is not set too low. However, when the CoCo bond-issuing firm takes excessive risk, causing a debt-induced collapse, CoCo bonds can become junior straight debt and the equity value may suddenly drop. Avdjiev et al. (2015) claimed that the contract design of a CoCo bond and the characteristics of the issuing firm are important determinants of its effects. However, in their opinion the beneficial effects of such bonds on loss absorbency and risk-taking incentives are rather weak. On the other hand, Gründl and Niedrig (2015) highlighted the benefits of CoCo bonds, arguing that they are effective in reducing risk-shifting towards taxpayers and enhancing banks' stability. They added that the current Solvency II standard formula for market risk, which relies on rudimentary risk weights, needs to improve because it fails to estimate the full risk of CoCo bonds. Song and Yang (2016) found that the risk-taking incentives and agency cost of debt increase if shareholders are allowed to choose their optimal CoCo bond conversion barriers by themselves. They also stressed that the risk-taking incentives and agency cost of debt decrease if CoCo bonds have an exogenously imposed conversion barrier.

Numerous studies have analysed the effects of convertible bonds, straight bonds etc. on financial markets. However, to the best of our knowledge, there are only four previous studies on market reactions to CoCo bond issuances. Avdjiev et al. (2015) and Vallée (2016) found that the reaction of credit default swap (CDS) spreads is significantly negative, whilst that of equity markets is not significant; however, they did not investigate the CoCo bond issue announcement periods. In a subsequent study, Ammann et al. (2017) found significant reductions in CDS spreads in response to CoCo bonds' post-issue announcements and a positive reaction of the equity market. By contrast, Liao et al. (2017) reported a negative reaction, but also detected differences across countries.

CoCo bonds modelling has also been discussed in the mathematical finance literature. For instance, in a seminal study, Ingersoll (1977) considered optimal policies for call and conversion for these assets on the basis of the criterion of dominance and applied techniques a la Black-Scholes to price convertible securities as contingent claims on the firm as a whole. Brennan and Schwartz (1977) priced convertible bond using a finite-difference method which required solving a partial-differential equation with some realistic boundary conditions. Brennan and Schwartz (1980) analysed the main features of these securities focusing in particular on their upside, which is subordinated to other corporate debt and has a lower coupon rate of an equivalent standard bond. Ho and Pfeffer (1996) estimated a two-factor model and found that the correlation between stock risk and interest rate risk affects CoCo bonds significantly; they also analysed the related portfolio analytics and hedging strategies. Tsiveriotis and Fernandes (1998) splitted convertible bonds into two components, a "cash-only" one which is subject to credit risk, and an equity one, which is not; they then used a pair of coupled partial differential equations to price CoCo bonds. Ayache et al. (2003) argued that this approach is flawed because it does not take into account the possibility of default by the issuing firm and proposed a more general framework based on a Poisson default process to price convertible securities. 
More recently, Milanov et al. (2019) developed models in terms of the free boundary value problem where the spatial variable is the underlying stock price and also provided a closed-form solution for CoCo bond pricing with practical relevance. Geon et al. (2019) put forward dynamic capital-ratio and debt-equity pricing models for convertible securities obtaining analytical solutions for CoCo bonds with fixed and floored conversion prices and showing how these can be applied in a variety of cases. Finally, Zaevski et al. (2019) proposed two alternative methods for deriving the partial differential equations (PDE) for the price of defaultable derivatives, the first based on a stochastic differential equation (SDE) stopped at a stochastic time, the second in which the stopping time is related to a jump process. They assumed in turn a Brownian motion and a Lévy process for the underlying asset price.

\section{Hypothesis development}

The studies above suggest that the design of CoCo bonds and the financial situation of the issuing bank determine their effects on investors. We focus on the coupon, maturity, issue size, trigger level, credit rating and conversion method as CoCo bonds' characteristics.

According to the BIS Quarterly Review by Avdjiev et al. (2013), approximately 64\% of CoCo bonds have tax-deductible coupons, while around $20 \%$ do not. The tax treatment of the remaining $16 \%$ of CoCos is currently under review. Therefore, although high coupon rates are not beneficial to issuers, this negative effect is somewhat mitigated by the favourable tax treatment. On the other hand, insurers clearly benefit from buying CoCo bonds owing to the high coupon rates compensating for the high issuing bank's risk (Gründl and Niedrig, 2015), which has proven to be very attractive in the current low-yield environment (Jaworskia et al., 2017).

In addition, the CoCo bond's trigger, often defined in terms of the ratio of common equity Tier 1 capital to risk-weighted assets, may affect its coupon rates (Avdjiev et al., 2015). Higher trigger levels indicate better bankruptcy protection for the issuing bank because of its early equity conversion. However, CoCo bond investors become more likely to internalise the negative financial consequences of the issuing banks as new shareholders from their early equity conversions. Therefore, CoCo bonds with a higher trigger level are more likely to have higher coupon rates to compensate for the increased likelihood of early equity conversion with its negative consequences that investors will have to bear.

The CoCo bond's equity conversion mechanism can also affect its coupon rates. There are two main conversion methods, namely mechanical equity conversion and principal write-down. CoCo bonds with mechanical equity conversion are cheaper to issue but require stricter mandates for investors (Avdjiev et al., 2015). Thus, CoCo bonds with this feature are likely to have higher coupon rates. Further, CoCo bonds with higher credit ratings are likely to have lower coupon rates as a compensation for the issuing banks being more financially sound. Accordingly, our first hypothesis is the following:

\section{$\mathrm{H}_{1}$ : Buyers prefer CoCo bonds with higher coupon rates and sellers prefer those with lower coupon rates.}

From the CoCo bond issuer's perspective, the trigger level selection is largely determined by the trade-off between regulatory capital eligibility and cost of issuance. CoCo bonds with low triggers have lower loss-absorbing capacity. They tend to be less expensive to issue and are usually used to boost Tier 2 capital in a cost-efficient manner while not being eligible to qualify as Additional Tier 1 capital which is relatively more expensive to raise. Over time, however, there has been increasing financial regulatory pressure for banks to boost their Tier 1 capital which requires trigger levels (= $\frac{\text { Common Equity Tier } 1 \text { Capital }}{\text { Risk Weighted Assets }} \geq 5.125 \%$ ) higher than those for Tier 2 capital (Avdjiev et al., 2013). Therefore, as the CoCo bond's trigger level rises, its cost of issuance rises making its coupon rate more likely to increase to compensate for this situation.

On the other hand, investors may perceive the trigger level of CoCo bonds as too low to spark a conversion, which may be seen as simply more leverage. Therefore, as the CoCo bond's trigger level increases and the likelihood of an early conversion rises, the issuing banks will experience an increase in bankruptcy protection (Ammann et al., 2017), despite the increase in the cost of issuance (Avdjiev et al., 2013), owing to the ongoing regulatory pressure. However, CoCo bond investors are assumed to be primarily fixed-income security investors who are less equipped to manage large losses than equity holders and may want to avoid equity conversions (Avdjiev et al., 2015). Otherwise, they can be forced to internalise the negative consequences of the poor performance of companies which induces CoCo bonds to convert (Ammann et al., 2017). To compensate for the higher trigger level which can cause early equity conversions, CoCo bonds may offer higher coupon rates to investors. Hence, our second hypothesis is the following:

\section{$\mathrm{H}_{2}$ : Buyers prefer CoCo bonds with lower trigger levels and sellers prefer those with higher trigger levels.}

The current equity-capital eligibility regulations do not distinguish between CoCo bonds with different loss absorption mechanisms, i.e., mechanical equity conversion and principal write-down. CoCo bonds with the former have dominated over the latter but the demand for the second category has been increasing over time. A possible reason is that fixed-income investors have mandates which often restrict them from holding CoCo bonds with mechanical equity conversions, but not CoCo bonds with principal write-down mechanisms; these involve less uncertainty about the payoff after the trigger level is broken through, which may facilitate their pricing and risk management (Avdjiev et al., 2015).

CoCo bonds with a mechanical equity conversion may reduce risk-taking incentives more effectively but exert negative pressure on the stock price when issued and dilute the existing shareholders ownerships with the conversion. On the other hand, 
those with a principal write-down feature are affected by the supervisors' judgement about bank solvency which leads to higher risk-taking incentives. Furthermore, CoCo bond issuance with a mechanical conversion mechanism produces negative pressure on the stock price while those with principal write-down feature have an insignificant impact on it (Avdjiev et al., 2015). However, they are cheaper for the issuers than those with a principal write-down feature and still satisfy the condition for regulatory capital eligibility under Basel III (Avdjiev et al., 2013). Consequently, Coco bonds with a mechanical equity conversion may have higher coupon rates than those with a principal write-down mechanism. This leads to the following third hypothesis:

$\mathrm{H}_{3}$ : Buyers prefer CoCo bonds with a principal write-down mechanism and sellers prefer those with a mechanical equity conversion.

Providing CoCo bonds' credit ratings has been a challenge for the credit rating agencies for three main reasons. First, the different regulatory treatment of CoCo bonds across jurisdictions makes it difficult to have consistent rating methodologies. Second, high-trigger CoCo bonds have the potential to cause more losses for CoCo bond holders ahead of the issuing bank's equity holders, which inverts the traditional hierarchy of investors and is an additional possibility the credit rating agencies need to consider. Third, the existence of the principal write-down feature (the discretionary trigger) creates valuation uncertainty, further complicating the rating process (Avdjiev et al., 2013).

For CoCo bonds not to convert, they should have high credit ratings which investors prefer to avoid internalising possible losses from the issuing companies. On the other hand, banks prefer issuing CoCo bonds when they feel a strong need to increase their bankruptcy protection, especially when their credit ratings are low. Consequently, CoCo bonds with a lower credit rating are more likely to offer higher coupon rates as a compensation to their investors. Therefore, our fourth hypothesis is the following:

\section{$\mathrm{H}_{4}$ : Buyers prefer CoCo bonds with a higher credit rating and sellers prefer those a with lower credit rating.}

In the Basel III framework, all Additional Tier 1 instruments must be perpetual. Therefore, approximately one third of CoCo bonds issued have no maturity date. The rest of the existing CoCo bonds with finite maturity dates are only eligible to obtain Tier 2 capital status under Basel III. Most of them have an original maturity of approximately 10 years (Avdjiev et al., 2013). With a longer or perpetual maturity, CoCo bond investors are likely to enjoy (generally higher) coupon payments than for other debt instruments over a long period, while the opposite holds for CoCo bond issuers. Thus, we formulate our fifth hypothesis as:

\section{$\mathrm{H}_{5}$ : Buyers prefer CoCo bonds with a longer maturity and sellers prefer those with a shorter maturity.}

CoCo issuance patterns are largely driven by the way Basel III is applied, or supplemented, by national regulators and the tax treatment in different jurisdictions. Banks are motivated to issue CoCo bonds by their need to satisfy the loss-absorbing capital requirements, especially in the UK. Approximately 64\% of CoCo bonds have tax-deductible coupons and the rest are either not so or are still under review depending on different countries' jurisdictions (Avdjiev et al., 2013). Asset managers, hedge funds and other banks usually purchase a significant amount of CoCo bonds. Investors from the UK, Europe, and the US are among the largest holders (Avdjiev et al., 2015). A large CoCo bond issue leads to sizeable equity conversions, possibly exceeding what would be required to eliminate all risk shifting incentives; instead, it can cause an excessive dilution effect among the existing shareholders (Martynova and Perotti, 2018). This leads to our sixth hypothesis, namely:

\section{$\mathrm{H}_{6}$ : Buyers prefer a smaller amount issued of CoCo bonds and sellers prefer a larger amount.}

In our analysis, we control for both the issuing bank's characteristics (credit risk, return on equity, size, price-to-book ratio and regulatory capital ratio ( $\left.\frac{\text { total regulatory capital }}{\text { total risk weighted assets }}\right)$ ) and the underlying economic conditions (real GDP growth and inflation).

\section{Methodology}

We assume that CoCo bond buyers prefer a higher bid yield-to-maturity (Bid_YTC) and safety measured by the spread of common equity tier 1 ratio (CET1_Ratio) on the CoCo bond's trigger level (TRI). Since many CoCo bonds are callable (Hesse, 2018; Vallée, 2019), we incorporate their bid YTC which CoCo bond buyers prefer to have a higher value. The common equity conversion or principal write-down of a CoCo bond is activated once the issuing bank's common equity tier 1 ratio goes below its predetermined trigger level. Thus, a higher common equity tier 1 ratio spread relative to the CoCo bond's trigger level implies a higher safety level for CoCo bond buyers. Accordingly, a higher safety-adjusted return YTC_SAR (=Bid_YTC $\times$ (CET1_Ratio - TRI)) indicates higher sensitivity of buyers' preferences to CoCo bonds. For simplicity, we call the spread of CET1_Ratio on the TRI the CET1_Spread (=CET1_Ratio - TRI). The following pooled panel regression is estimated:

$$
\text { YTC SAR } R_{t, i, j}=\alpha_{t}+\beta_{t, i, j, 1} \times \text { CoCo_Char }_{t, i, j}+\beta_{t, i, j, 2} \times \text { Bank_Ctrl }_{t, i, j}+\beta_{t, i, j, 3} \times \text { Economic_Ctrl }_{t, i, j}
$$


where $\alpha_{t}$ is the intercept and $\beta_{t, i, j}$ is the vector of coefficients associated with the covariates, which are the CoCo bonds' characteristics (CoCo_Char), bank control (Bank_Ctrl) and economic control (Economic_Ctrl) variables of issuing bank $i$ in country $j$ at time $t$. The CoCo bonds' characteristics considered are coupon (CPN in \%), maturity (MAT: this is a binary variable equal to one if permanent and zero otherwise), the amount issued (AMT: we use the natural logarithm in US\$), the trigger level (\%), conversion (CON: this is a binary variable that equals one in the event of mechanical equity conversion and zero in the event of a permanent write-down, a partial permanent write-down and a temporary write-down) and credit rating (CRD: the average credit rating among Moody, S\&P and Fitch ratings where each credit rating increment is 1 , and the highest (Aaa, AAA) and lowest (Ca, CCC and below) credit ratings are 19 and 0 respectively). As for the CoCo bond issuing firm characteristics, these include the credit default swap spread (CDS), the return on common equity (ROE), firm size (SIZE) which is the natural logarithm of the firm's total assets, the price-to-book value ratio (P/B ratio) and total regulatory capital to risk-weighted asset (TRC/RWA). Finally, the economic control variables added to the regressions are real GDP (\%) and the consumer price index (CPI). We also run regression (1) by replacing the safety-adjusted return (YTC_SAR) with the safety measure itself (CET1_Spread) for CoCo bonds in order to analyse separately the preference response based only on the risk component.

We then run a multinomial logistic regression to shed light on the different behaviour of CoCo bonds buyers with low (25th), medium (50th) and high (75th) safety-adjusted return profiles. This enables us to obtain different buyers and sellers' preferences scores (which we assume to be mutually exclusive) for the low, medium and high percentiles as probability measures between 0 and 1 . The dependent variables (CoCo bond buyers' preference scores) YTC_SCORE_25, YTC_SCORE_50 and YTC_SCORE_75 are defined as the safety-adjusted returns (YTC_SAR) which are compared to the corresponding 25th, 50th and 75th percentile values within each year, and take value one, two and three if greater than these percentiles and zero otherwise. In other words, buyers are assumed to prefer to hold CoCo bonds with a higher safety-adjusted return (YTC_SAR) than for all other CoCo bonds within a year based on their annual 25th, 50th and 75th percentile safety-adjusted return values. Therefore, the estimated regression is the following:

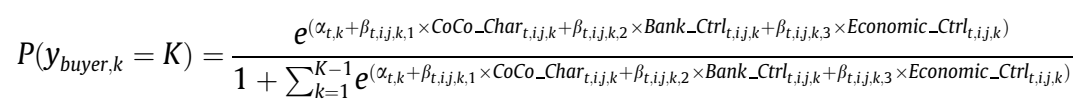

Eq. (1) shows that there are $K$ possible outcomes (i.e., zero $(k=1), 25$ th $(k=2), 50$ th $(k=3)$ and 75 th $(k=4)$ percentiles), specifically four in our case. $P\left(y_{\text {buyer }, k}=K\right)$ is the buyer's preference probability based on the binary dependent variable $y_{\text {buyer }, k}$ which is equal to one, two and three if the buyer's safety adjusted return (YTC_SAR) of a CoCo bond is higher than its associated percentile category $k$ (e.g., YTC_SCORE_25, YTC_SCORE_50 and YTC_SCORE_75) of all CoCo bonds within the same year, respectively, and zero otherwise.

Then we calculate the CoCo bond seller's preference score $P\left(y_{\text {seller }, k}=K\right)$ by subtracting the CoCo bond buyers' preference score from one. We assume that the CoCo bond buyers and sellers' preferences are mutually exclusive, namely:

$$
\begin{aligned}
& P\left(y_{\text {seller }, k}=K\right) \\
& =1-P\left(y_{\text {buyer }, k}=K\right)
\end{aligned}
$$

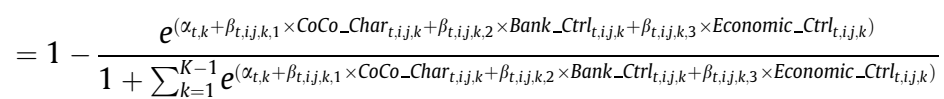

To determine the partial impact of a marginal change in one of the explanatory variables $q$ on the probability of being in the 75th, 50th and 25th percentiles of safety adjusted returns, we derive the conditional probability for buyers $\left(\Delta P_{\text {buyer }}\right)$ and sellers $\left(\Delta P_{\text {seller }}\right)$ based on Eqs. (2) and (3), respectively, as follows:

$$
\begin{aligned}
& \Delta P_{\text {buyer }}=P\left(y_{\text {buyer }, k}=K \mid \Delta z_{t, i, j, k, m}=1, \Delta z_{t, i, j, k, n}=0, m \neq n\right) \\
& =\frac{e^{\beta_{t, i, k}}}{1+\sum_{k=1}^{K-1} e^{\beta_{t, i, k}}} \\
& \Delta P_{\text {seller }}=P\left(y_{\text {seller }, k}=K \mid \Delta z_{t, i, j, k, m}=1, \Delta z_{t, i, j, k, n}=0, m \neq n\right) \\
& =1-\Delta P_{\text {buyer }} \\
& =1-\frac{e^{\beta_{t, i, k}}}{1+\sum_{k=1}^{K-1} e^{\beta_{t, i, k}}}
\end{aligned}
$$

where

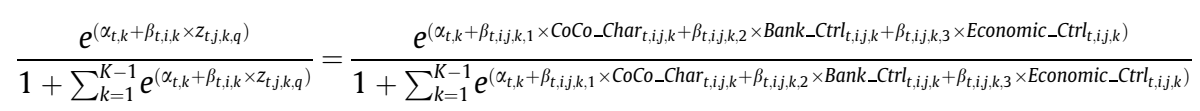


The column vector $z_{t, j, k, q}$ contains all explanatory variables $(q=\mathrm{CPN}$, TRI, CON, $\cdots)$ at time $t$ in country $j$ with $K(=4)$ possible outcomes (i.e., zero $(k=1), 25$ th $(k=2), 50$ th $(k=3)$ and 75 th $(k=4)$ percentiles). We add the YTC $\left(\Delta P_{\text {buyers }}^{Y T C}\right.$ and $\left.\Delta P_{\text {sellers }}^{Y T C}\right)$ or YTM $\left(\Delta P_{\text {buyers }}^{Y T M}\right.$ and $\Delta P_{\text {sellers }}^{Y T M}$ ) superscript if the conditional probability uses either of these to calculate its safety-adjusted return.

We estimate preference scores for CoCo bonds considering country-specific market competitiveness using the Herfindahl index and the issuing or holding Coco bond amount for each financial firm. We first compute the Herfindahl indices for Coco bond buyers and sellers in each country assuming that the total number of firms within a country is $N$ as shown in Eqs. (6) and (7) below. High (low) values of (6) and (7) indicate high (low) concentration (degree of competition) of the CoCo bond market in country $j$.

$$
\begin{aligned}
& s_{\text {countryj }}^{\text {buyer }}=\sum_{i=1}^{N}\left(\frac{\text { holding Coco bond amount }_{\text {firmi,countryj }}{ }^{2}}{\text { holdingCocobondamount }_{\text {countryj }}}\right)^{2} \\
& s_{\text {countryj }}^{\text {seller }}=\sum_{i=1}^{N}\left(\frac{\text { issued Coco bond amount }_{\text {firmi,countryj }}{ }^{2}}{\text { issued Coco bond amount }{ }_{\text {countryj }}}\right.
\end{aligned}
$$

We assume that in a highly competitive CoCo bond market both buyers and sellers have stronger trading power. We use the total CoCo bond issue size for all $N$ firms in country $j$ as a measure for the CoCo bond market concentration (or degree of competition) in that country as in Eqs. (6) and (7) above; the inverse of the Herfindahl index increases with the degree of competition of the CoCo bond market in country $j$. The preference scores are then rescaled using the CoCo bond market size of each country

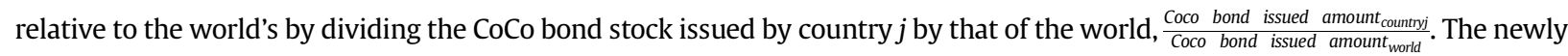
calculated Coco bond preference scores are therefore those specified in equation (8) and (9):

$$
\begin{aligned}
& P_{i, \text { buyer }, \text { country j }}^{\text {preference score }}=P\left(y_{\text {buyer }, k}=K\right) \times \underbrace{\frac{1}{s_{\text {country } j}^{\text {buyer }}} \times \frac{\text { Coco bond issued amount }}{\text { Country } j}}_{\text {buyers' market power score for country } j}
\end{aligned}
$$

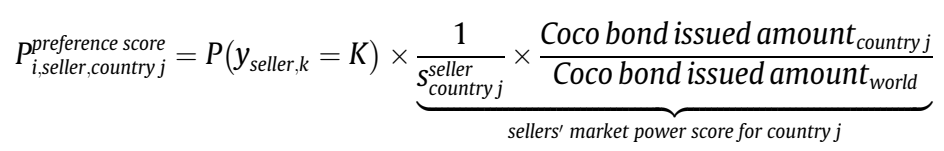

It should be immediately apparent that a country's Coco bond preference scores are higher when its markets are highly competitive and its average trading volumes are higher than the world's.

As a robustness check, we repeat the above exercise by replacing bid YTC (yield-to-call) with bid YTM (yield-to-maturity) which disregards the possible callable feature of CoCo bonds. We assume that CoCo bond buyers prefer a higher bid YTM but dislike risk measured by the CDS spread. Therefore, the dependent variables become YTM_SCORE_25, YTM_SCORE_50 and YTM_SCORE_75 defined as Bid_YTM $\times$ CET1_Spread (=YTM_SAR) which is compared to the corresponding 25th, 50th and 75th percentile values within each year, respectively, and takes value one, two and three if greater than these percentiles and zero otherwise.

\section{Data and empirical results}

\subsection{Data sources and description}

We collect CoCo bond data from Bloomberg between 11 May 2009 and 10 January 2020 using the SRCH@COCO command which yields an initial sample of 846 CoCo bonds from all over the world. Then we select those with the loss-absorbing property, which leaves 754 CoCo bonds from 37 countries between 1 April 2010 and 18 December 2019 and their corresponding issuing firm tickers. The CoCo bond's characteristics considered are: coupon (CPN in \%), maturity (MAT: a binary variable showing one if permanent and zero otherwise), amount issued (AMT in US \$), trigger level (TRI in \%), ${ }^{1}$ conversion (CON: a binary variable that equals one in the event of mechanical equity conversion and zero in the event of principal write-down including permanent write-down, partial permanent write-down and temporary write-down) and credit rating (CRD: the average credit rating among Moody, S\&P and Fitch ratings where each credit rating increment is 1 , with 19 being the highest (Aaa, AAA) and 0 the lowest (Ca, CCC or below)).

As for the CoCo bond issuing firm characteristics and economic control variables, we also collect the data from Bloomberg and use the 6 months lagged ones vis-à-vis the CoCo bond data to avoid hindsight bias. The CoCo bonds' characteristics considered are: CDS spread (CDS), ${ }^{2}$ return on common equity (ROE), firm size (SIZE: the natural logarithm of the firm's total

\footnotetext{
1 It is an accounting trigger, the common equity tier 1 (CET1) ratio ( $=\frac{\text { common equity tier } 1 \text { capital }}{\text { risk-weighted assets }} \times 100$ ) or a solvency trigger based on a predetermined solvency ratio.

${ }^{2}$ As for our CDS spread, we use the five-year CDS spread for the company implied by the Bloomberg Issuer Default Risk Model Likelihood of Default. The unit is in basis points.
} 
asset), price-to-book value ratio $(\mathrm{P} / \mathrm{B})$ and total regulatory capital to risk-weighted asset (TRC/RWA). The economic control variables used are real GDP growth (RGDP in yearly percentage change) and the consumer price index (CPI in yearly percentage change); the dependent variables (CoCo bond buyers' preference scores) YTC_SCORE and YTM_SCORE which are equal to one, two and three if their corresponding safety-adjusted returns, YTC_SAR and YTM_SAR, are greater or equal to the 25th, 50th and 75th percentiles of the yearly overall CoCo bonds, respectively, and zero otherwise. We winsorise all variables at the 1 st and 99 th percentiles. Table 1 shows summary statistics for the variables used for the analysis.

\section{Table 1}

Summary statistics. The following tables show the summary statistics of our overall data (Panel A), and CoCo bonds issue per country (Panel B), region (Panel C) of our sample between 1 April 2010 and 18 December 2019 and expected impact of our regressors on the CoCo bond buyers and sellers' preference scores (Panel D). In Panel A, we show the CoCo bonds, their issuing firms and the underlying economic characteristics. The CoCo bonds' characteristics considered are: coupon (CPN in \%), maturity (MAT), amount issued (AMT in US \$), trigger level (TRI in \%), conversion (CON) and credit rating (CRD). The CoCo bond issuing firm characteristics included are: CDS spread (CDS in bps), return on common equity (ROE), total assets (TA in million US \$), price-to-book value ratio (P/B) and total regulatory capital to risk-weighted asset (TRC/RWA). The economic control variables are real GDP growth (RGDP in yearly percentage change), consumer price index (CPI in yearly percentage change). We use CoCo bond's bid yield-to-call (Bid_YTC in \%), yield-to-maturity (Bid_YTM in \%), common equity tier 1 ratio (CET1_Ratio in \%) and trigger level (TRI) to produce our dependent variables: safety adjusted returns YTC_SAR (=Bid_YTC × (CET1_Ratio - TRI)) and YTM_SAR (=Bid_YTM $\times($ CET1_Ratio - TRI)) and their corresponding binary variables (YTC_SCORE and YTM_SCORE) which are our CoCo bond investors' preference score measures; these are equal to one, two and three if greater or equal to the 25th, 50th and 75th percentiles of the overall CoCo bonds within each year, respectively, and zero otherwise. We report the mean, median, standard deviation (Std.), 75th percentile, 25th percentile and total number of observations ( $N$ ). In Panel B and C, we show the CoCo bond issuing countries and regions in our sample, respectively, with their issue frequencies and amounts (in US \$). Panel D shows the expected coefficients' signs of our regressors on CoCo bond buyers and sellers' preference scores.

\begin{tabular}{|c|c|c|c|c|c|c|}
\hline \multicolumn{7}{|c|}{ Panel A. Overall data } \\
\hline & Mean & Median & Std. & 75th & 25th & $N$ \\
\hline CPN (\%) & 6.04 & 5.95 & 2.18 & 7.38 & 5.00 & 754 \\
\hline MAT & 0.89 & 1.00 & 0.32 & 1.00 & 1.00 & 754 \\
\hline AMT (\$) & $883,792,184$ & $500,000,000$ & $1,209,247,069$ & $1,250,000,000$ & $56,275,968$ & 754 \\
\hline TRI (\%) & 5.38 & 5.13 & 1.06 & 5.13 & 5.13 & 754 \\
\hline CON & 10.60 & 12.00 & 2.08 & 12.00 & 9.00 & 754 \\
\hline CRD & 0.22 & 0.00 & 0.42 & 0.00 & 0.00 & 754 \\
\hline CDS (bps) & 246.42 & 147.00 & 210.48 & 559.88 & 71.00 & 754 \\
\hline ROE (\%) & 14.62 & 13.10 & 10.15 & 25.99 & 6.22 & 754 \\
\hline TA $(\$ M)$ & 14.94 & 14.08 & 3.91 & 19.47 & 12.19 & 754 \\
\hline $\mathrm{P} / \mathrm{B}$ & 2.47 & 2.20 & 1.57 & 4.04 & 0.88 & 754 \\
\hline TRC/RWA (\%) & 22.08 & 20.50 & 6.48 & 29.32 & 16.41 & 754 \\
\hline RGDP & 3.24 & 2.35 & 2.85 & 5.93 & 1.33 & 754 \\
\hline CPI (\%) & 2.86 & 2.20 & 2.50 & 4.63 & 0.90 & 754 \\
\hline CET1_Ratio (\%) & 18.92 & 16.00 & 7.08 & 27.08 & 12.62 & 754 \\
\hline Bid_YTC (\%) & 8.59 & 7.26 & 4.16 & 13.46 & 5.51 & 754 \\
\hline Bid_YTM (\%) & 7.69 & 7.41 & 2.96 & 10.78 & 5.31 & 754 \\
\hline YTC_SAR (\%) & 115.26 & 163.53 & 59.69 & 163.53 & 49.41 & 754 \\
\hline YTM_SAR (\%) & 107.81 & 150.15 & 54.01 & 150.15 & 48.79 & 754 \\
\hline YTC_SCORE & 2.38 & 3.00 & 1.03 & 3.00 & 2.00 & 754 \\
\hline YTM_SCORE & 2.41 & 3.00 & 1.01 & 3.00 & 2.00 & 754 \\
\hline
\end{tabular}

Panel B. CoCo bonds issue per country

\begin{tabular}{|c|c|c|}
\hline Country & Counts of issue & Total issued amount (\$) \\
\hline Australia & 7 & $5,344,615,000$ \\
\hline Austria & 18 & $3,879,176,800$ \\
\hline Belgium & 5 & $5,361,122,000$ \\
\hline Brazil & 21 & $24,647,710,000$ \\
\hline China & 61 & $232,432,714,180$ \\
\hline Colombia & 2 & $1,300,000,000$ \\
\hline Croatia & 1 & $45,328,800$ \\
\hline Cyprus & 3 & $597,388,419$ \\
\hline Czech & 3 & $145,652,612$ \\
\hline Denmark & 34 & $6,327,318,256$ \\
\hline Estonia & 1 & $2,730,360$ \\
\hline Finland & 13 & $7,773,033,234$ \\
\hline France & 45 & $51,485,409,500$ \\
\hline Georgia & 3 & $350,000,000$ \\
\hline Germany & 27 & $11,304,697,344$ \\
\hline Hungary & 1 & $113,028,000$ \\
\hline India & 23 & $4,525,668,720$ \\
\hline Indonesia & 1 & $7,380,070$ \\
\hline Ireland & 5 & $3,421,790,000$ \\
\hline Israel & 9 & $1,235,243,695$ \\
\hline Italy & 22 & $17,100,108,390$ \\
\hline Japan & 26 & $37,320,407,370$ \\
\hline
\end{tabular}




\begin{tabular}{|c|c|c|}
\hline \\
\hline Luxembourg & 3 & $230,100,245$ \\
\hline Malaysia & 21 & $4,164,713,650$ \\
\hline Mexico & 21 & $14,600,000,000$ \\
\hline Netherlands & 16 & $18,854,187,000$ \\
\hline New Zealand & 1 & $108,303,750$ \\
\hline Norway & 134 & $5,026,239,169$ \\
\hline Portugal & 3 & $4,788,529,000$ \\
\hline Russia & 36 & $17,562,596,500$ \\
\hline Slovakia & 1 & $115,595,000$ \\
\hline South Africa & 1 & $328,340,000$ \\
\hline Spain & 28 & $30,883,886,740$ \\
\hline Sweden & 24 & $7,210,411,550$ \\
\hline Switzerland & 67 & $75,646,575,201$ \\
\hline Turkey & 2 & $1,300,000,000$ \\
\hline United Kingdom & 65 & $92,043,389,121$ \\
\hline \multicolumn{3}{|c|}{ Panel C. CoCo bonds issue per region } \\
\hline Region & Counts of issue & Total issued amount $(\$)$ \\
\hline Europe & 569 & $362,803,536,937$ \\
\hline Asia \& Pacific & 140 & $283,903,802,740$ \\
\hline South/Latin America & 44 & $40,547,710,000$ \\
\hline Africa & 1 & $328,340,000$ \\
\hline \multicolumn{3}{|c|}{ Panel D. Expected impact on the buyers and sellers' preference scores } \\
\hline \multirow[t]{2}{*}{ Factors } & \multicolumn{2}{|c|}{ Expected coefficient sign } \\
\hline & \multicolumn{2}{|l|}{ Buyers } \\
\hline CPN (\%) & + & - \\
\hline MAT & + & - \\
\hline AMT (\$) & - & + \\
\hline TRI (\%) & - & + \\
\hline CON & - & + \\
\hline CRD & + & - \\
\hline CDS (bps) & - & + \\
\hline ROE (\%) & + & - \\
\hline $\mathrm{TA}(\$ \mathrm{M})$ & + & - \\
\hline $\mathrm{P} / \mathrm{B}$ & + & - \\
\hline TRC/RWA (\%) & + & - \\
\hline RGDP & + & - \\
\hline CPI (\%) & - & + \\
\hline
\end{tabular}

According to Panel A in Table 1, most CoCo bonds have coupon rates around 6\%, permanent maturities (about 89\%), a trigger level between $5 \%$ and $6 \%$, credit ratings between $\mathrm{Ba} 2 / \mathrm{BB} / \mathrm{BB}$ and $\mathrm{Ba} 1 / \mathrm{BB}+\mathrm{BB}+$ according to Moody/S\&P/Fitch credit ratings, and $22 \%$ have the mechanical equity conversion property, while the remaining $78 \%$ have principal write-down features. Most of the variables in our sample do not exhibit a large difference between the mean and the median and have relatively non-skewed distributions, except for AMT, TA and CDS. There is a clustering of low AMT, TA and CDS values with a rightskewed distribution. This indicates that the larger CoCo bond amount (AMT) tends to be issued by fewer large-size banks (TA) with higher risk (CDS) than on average in our sample. The CoCo bond issue frequency is highest for Norway while China and United Kingdom have the largest CoCo bond issued amount in our sample (Table 1, Panel B). Europe has the largest CoCo bond issued amount compared to all other regions (Table 1, Panel C).

In Panel D, we show the expected signs of the coefficients on the CoCo bond and issuing bank's characteristics affecting the buyers and sellers' preference scores. The six CoCo bond factors (CPN, TRI, CON, CRD, MAT and AMT) exhibit coefficient signs consistent with the hypotheses developed in Section 3. The issuing bank's characteristics (ROE, TA, P/B, TRC/RWA and CDS) are expected to have a positive (negative) impact on the buyers' (sellers') preference. Specifically, buyers prefer the issuing banks to be sound (TRC/RWA) and have a lower default probability (CDS), but large enough (TA) to warrant support from the government who is more likely to bailout banks which are too-big-to-fail. They also want the issuing banks to be sufficiently attractive in terms of profitability (ROE) and the growth potential reflected in their valuation (P/B). Sellers are expected instead to exhibit the opposite response: they are more likely to issue CoCo bonds when they are not financially sound, have lower regulatory capital (TRC/RWA) with a higher default risk (CDS), and are not large enough (TA) to obtain a government bailout during unexpected financial emergencies. Their difficulties may increase if they are not sufficiently profitable $(\mathrm{ROE})$ and their valuation $(\mathrm{P} / \mathrm{B})$ suggests a weak growth potential $(\mathrm{P} / \mathrm{B})$. As for the economic control variables, we expect buyers to prefer to invest in CoCo bonds under favourable economic conditions, i.e., when real GDP (RGDP) is higher, whilst sellers may face more unexpected financial losses when the economy is weaker. We also expect buyers to prefer to invest in CoCo bonds when their real purchasing power is not negatively affected by a rising inflation rate (CPI), i.e., during periods of decreasing inflation, in contrast to the sellers. 


\subsection{Empirical results}

\subsubsection{CoCo bond preference analysis}

Table 2 presents the pooled panel regressions results showing how the CoCo bond buyers' safety-adjusted return (YTC_SAR and YTM_SAR) and the safety measure (CET1_Spread) are affected by the CoCo bond and issuing bank's characteristics while controlling for the underlying economic condition. As mentioned earlier, we assume that buyers have a preference for CoCo bonds with higher safety adjusted returns. Overall, we find that buyers prefer to have CoCo bonds with high coupon rates $\left(\mathrm{H}_{1}\right)$, a good credit rating $\left(\mathrm{H}_{4}\right)$ and a low trigger level $\left(\mathrm{H}_{2}\right)$ with a smaller amount issued $\left(\mathrm{H}_{6}\right)$ by large sized, financially sound banks with high profitability and sufficient regulatory capital. These results confirm our first, second, fourth and sixth hypotheses - in other words, buyers prefer to have CoCo bonds with a high return-to-risk, a smaller chance to convert with a low trigger level (to avoid internalising the negative financial consequences of the issuing banks) and also a smaller issued amount (to prevent potential dilution of the existing shareholders' ownerships) and large issuing banks with high profitability that can afford high coupon payments and have low default risk.

A higher CET1_Spread indicates more common equity tier 1 (CET1) capital injection on the part of banks to increase their financial safety level. We find that a higher trigger level of CoCo bonds increases the risk-taking behaviour of the issuing banks as they become more relaxed given the CoCo bond's bankruptcy protection and reduce their common equity tier 1 capital level further. However, CoCo bonds with increasing coupon rates (CPN $\times$ TRI) or the equity conversion method $($ TRI $\times$ CON) make the issuing banks more worried about the resulting financial pressures and reduce their risk-taking behaviour (by accumulating more CET1 capital). The equity conversion mechanism is likely to have higher coupon rates to compensate for its relatively lower issuing cost compared to the principal write-down feature. Therefore, when the coupon rate increases for the CoCo bonds using the equity conversion method (CPN $\times$ CON), the financial pressure for the issuing banks can become even worse and they might reduce their CET1 capital which is too costly to hold. When there is an increase in CoCo bond issuance, the issuing banks perceive a smaller need to have CET1 capital protection. However, when this is accompanied by an increase in the return on the equity of the issuing banks, this indicates an increase in their risk and a greater need of regulatory capital protection (AMT $\times$ ROE). Overvalued banks are exposed to the risk of their financial value falling. Large sized banks are more likely to be connected with other banks and to become too-big-to-fail during financial crisis. An increase in total regulatory capital is likely to increase the common equity tier 1 capital to risk-weighted asset ratio since common equity tier 1 capital is the core element of the total regulatory capital. Therefore, CoCo bond issuing banks which are overvalued, large sized and financially solvent tend to have more CET1 capital protection.

\section{Table 2}

CoCo bond preference score analysis. The following tables present the pooled panel regression results with CoCo bond buyer's safety-adjusted returns (SAR) in terms of (1) YTC_SAR, (2) YTM_SAR and (3) their safety measure CET1_Spread (=CET1_Ratio - TRI) as dependent variables and CoCo bond (between 1 April 2010 and 18 December 2019), its issuing bank and economic characteristics as independent variables. The CoCo bonds' characteristics considered are: coupon (CPN in \%), maturity (MAT), amount issued (AMT in US \$), trigger level (TRI in \%), conversion (CON) and credit rating (CRD). The CoCo bond issuing firm characteristics included are: return on common equity (ROE), firm size (SIZE), price-to-book value ratio (P/B) and total regulatory capital to risk-weighted asset (TRC/RWA). The economic control variables are real GDP growth (RGDP in yearly percentage change) and consumer price index (CPI in yearly percentage change). For our dependent variables, we use YTC_SAR (=Bid_YTC $\times($ CET1_Ratio - TRI)) and YTM_SAR (=Bid_YTM $\times($ CET1_Ratio - TRI $))$ as for our CoCo bond investors' preference score measures. We report F-test and Adjusted $R^{2}$ as our goodness-of-fit measures and $N$ as the total number of observations. The standard errors are in parentheses. ${ }^{*}$ stands for significance at the $10 \%$ level, ${ }^{* * *}$ at the $5 \%$ level and ${ }^{* * *}$ at the $1 \%$ level.

\begin{tabular}{|c|c|c|c|}
\hline & $\begin{array}{l}\text { (1) } \\
\text { YTC_SAR }\end{array}$ & $\begin{array}{l}(2) \\
\text { YTM_SAR }\end{array}$ & $\begin{array}{l}\text { (3) } \\
\text { CET1_Spread }\end{array}$ \\
\hline (Intercept) & $\begin{array}{l}82.62 \\
(1.584)\end{array}$ & $\begin{array}{l}\text { 93.9* } \\
(1.652)\end{array}$ & $\begin{array}{l}\text { 17.369*** }^{* * *} \\
(2.853)\end{array}$ \\
\hline CPN & $\begin{array}{l}3.102 * * \\
(3.305)\end{array}$ & $\begin{array}{l}3.005^{* * *} \\
(2.938)\end{array}$ & $\begin{array}{l}0.111 \\
(1.017)\end{array}$ \\
\hline $\mathrm{CPN} \times \mathrm{TRI}$ & $\begin{array}{l}0.716 \\
(1.005)\end{array}$ & $\begin{array}{l}0.705 \\
(0.908)\end{array}$ & $\begin{array}{l}0.169^{* *} \\
(2.036)\end{array}$ \\
\hline $\mathrm{CPN} \times \mathrm{CON}$ & $\begin{array}{l}1.048 \\
(0.445)\end{array}$ & $\begin{array}{l}1.526 \\
(0.595)\end{array}$ & $\begin{array}{l}-0.721^{* * *} \\
(-2.624)\end{array}$ \\
\hline $\mathrm{CPN} \times \mathrm{CRD}$ & $\begin{array}{l}-{ }^{-0.898}{ }^{*} \\
(-1.889)\end{array}$ & $\begin{array}{l}-0.777 \\
(-1.5)\end{array}$ & $\begin{array}{l}0.125^{* *} \\
(2.251)\end{array}$ \\
\hline TRI & $\begin{array}{l}-5.318^{* * *} \\
(-2.739)\end{array}$ & $\begin{array}{l}-5.5866^{* * *} \\
(-2.639)\end{array}$ & $\begin{array}{l}-1.7^{* * *} \\
(-7.501)\end{array}$ \\
\hline $\mathrm{TRI} \times \mathrm{CON}$ & $\begin{array}{l}-1.938 \\
(-0.456)\end{array}$ & $\begin{array}{l}-0.441 \\
(-0.095)\end{array}$ & $\begin{array}{l}1.005^{* *} \\
(2.025)\end{array}$ \\
\hline $\mathrm{CON}$ & $\begin{array}{l}-6.969 \\
(-1.424)\end{array}$ & $\begin{array}{l}-5.167 \\
(-0.968)\end{array}$ & $\begin{array}{l}0.842 \\
(1.474)\end{array}$ \\
\hline
\end{tabular}


Table 2 (continued)

\begin{tabular}{|c|c|c|c|}
\hline & $\begin{array}{l}(1) \\
\text { YTC_SAR }\end{array}$ & $\begin{array}{l}(2) \\
\text { YTM_SAR }\end{array}$ & $\begin{array}{l}\text { (3) } \\
\text { CET1_Spread }\end{array}$ \\
\hline CRD & $\begin{array}{l}3.042 * * \\
(2.617)\end{array}$ & $\begin{array}{l}2.871^{* *} \\
(2.266)\end{array}$ & $\begin{array}{l}-0.247^{*} \\
(-1.819)\end{array}$ \\
\hline MAT & $\begin{array}{l}-6.862 \\
(-1.079)\end{array}$ & $\begin{array}{l}-5.847 \\
(-0.843)\end{array}$ & $\begin{array}{l}-1.136 \\
(-1.529)\end{array}$ \\
\hline AMT & $\begin{array}{l}-7.289^{* * *} \\
(-5.882)\end{array}$ & $\begin{array}{l}-9.148 * * * \\
(-6.774)\end{array}$ & $\begin{array}{l}-1.277^{* * *} \\
(-8.826)\end{array}$ \\
\hline AMT $\times$ ROE & $\begin{array}{l}0.265^{* *} \\
(2.313)\end{array}$ & $\begin{array}{l}0.24^{*} \\
(1.923)\end{array}$ & $\begin{array}{l}0.037^{* * *} \\
(2.743)\end{array}$ \\
\hline $\mathrm{AMT} \times \mathrm{P} / \mathrm{B}$ & $\begin{array}{l}-0.043 \\
(-0.062)\end{array}$ & $\begin{array}{l}0.438 \\
(0.575)\end{array}$ & $\begin{array}{l}0.07 \\
(0.852)\end{array}$ \\
\hline CDS & $\begin{array}{l}0.198 \\
(0.17)\end{array}$ & $\begin{array}{l}0.866 \\
(0.681)\end{array}$ & $\begin{array}{l}-0.061 \\
(-0.449)\end{array}$ \\
\hline ROE & $\begin{array}{l}0.723 * \\
(2.27)\end{array}$ & $\begin{array}{l}0.846^{* *} \\
(2.437)\end{array}$ & $\begin{array}{l}0.083^{* *} \\
(2.232)\end{array}$ \\
\hline $\mathrm{P} / \mathrm{B}$ & $\begin{array}{l}2.942 \\
(1.45)\end{array}$ & $\begin{array}{l}\text { 3.984* } \\
(1.802)\end{array}$ & $\begin{array}{l}0.635 * * * \\
(2.682)\end{array}$ \\
\hline SIZE & $\begin{array}{l}2.609 \\
(3.249)\end{array}$ & $\begin{array}{l}2.997^{* * *} \\
(3.424)\end{array}$ & $\begin{array}{l}0.227^{* *} \\
(2.417)\end{array}$ \\
\hline TRC/RWA & $\begin{array}{l}1.071^{* *} \\
(2.343)\end{array}$ & $\begin{array}{l}0.952^{*} \\
(1.912)\end{array}$ & $\begin{array}{l}0.45^{* * *} \\
(8.434)\end{array}$ \\
\hline RGDP & $\begin{array}{l}-2.308 * * \\
(-2.37)\end{array}$ & $\begin{array}{l}-2.543^{* *} \\
(-2.395)\end{array}$ & $\begin{array}{l}-0.267^{* *} \\
(-2.35)\end{array}$ \\
\hline CPI & $\begin{array}{l}-4.235^{* * *} \\
(-3.722)\end{array}$ & $\begin{array}{l}-4.296 * * \\
(-3.465)\end{array}$ & $\begin{array}{l}-0.932^{* * *} \\
(-7.017)\end{array}$ \\
\hline Year Fixed Effect & Yes & Yes & Yes \\
\hline Region Fixed Effect & Yes & Yes & Yes \\
\hline F-test & $14.66^{* * *}$ & $15.74^{* * *}$ & $28.51^{* * *}$ \\
\hline Adjusted $R^{2}$ & 0.36 & 0.38 & 0.53 \\
\hline$N$ & 754 & 754 & 754 \\
\hline
\end{tabular}

We then extend our analysis to investigate how buyers of CoCo bonds with high, medium and low safety-adjusted return profiles are affected by the characteristics of CoCo bonds and their issuing banks to gain a better understanding of the differences in their preference responses. Table 3 displays the results from the preference score multinomial logistic regression analysis based on Eqs. (2) and (3). ${ }^{3}$ We use three different binary dependent variables, YTC_SCORE_25, YTC_SCORE_50 and YTC_SCORE_75 in Panel A, which are equal to one, two and three if the Bid_YTC $\times$ CET1_Spread is larger than the 25th, 50th and 75th percentile of all CoCo bond's Bid_YTC $\times$ CET1_Spread within the same year, respectively.

We expect the CoCo bond sellers' response to the regressors to be opposite to the buyers' one, as shown in Eqs. (2) and (3), therefore we only report the first set of coefficients in Table 2. We then estimate the marginal buyer's response of preference probability $\Delta P_{\text {buyers }}^{Y T C}$ for each regressor. As a robustness check, we replicate the Panel A results in Panel B by replacing the three dependent variables YTC_SCORE_25, YTC_SCORE_50 and YTC_SCORE_75 with YTM_SCORE_25, YTM_SCORE_50 and YTM_SCORE_75, respectively, which are equal to one, two and three if the Bid_YTM $\times$ CET1_Spread is larger than the 25th, 50th and 75th percentile of all CoCo bond's Bid_YTM $\times$ CET1_Spread within the same year, respectively.

Overall, the results of Tables 2 and 3 concerning the preference score responses are similar in terms of CoCo bond and issuing bank factors which are significant. We find that buyers prefer to have CoCo bonds with high coupon rates with the principal write-down feature $\left(\mathrm{H}_{3}\right)$ and perpetual maturity $\left(\mathrm{H}_{5}\right)$ issued in smaller amounts by overvalued, large sized banks with sufficient regulatory capital and low credit risk. These findings confirm our third and fifth hypotheses.

In general, buyers of CoCo bonds with higher safety-adjusted returns (YTC_SCORE and YTM_SCORE) tend to prefer higher coupon payments: as they hold CoCo bonds with a higher yield and a lower risk (i.e., higher Bid_YTC $\times$ CET1_Spread or Bid_ YTM $\times$ CET1_Spread), they are likely to seek even higher coupon payments as shown by the higher coefficient $\left(\Delta P_{\text {buyers }}^{Y T C}\right.$ and

${ }^{3}$ The Pearson correlation matrix reported in Appendix A indicates that the multinomial logistic regressions are not affected by multi-collinearity. 
$\Delta P_{\text {buyers }}^{Y T M}$ ) of CPN for the higher preference score percentiles YTC_SCORE_75 and YTM_SCORE_75. However, as shown by the CET1_Spread analysis in Table 2, an increase in the coupon rate of a CoCo bond with the equity conversion feature $(\mathrm{CPN} \times \mathrm{CON})$ may put financial pressure on the issuing bank since this mechanism is likely to entail high coupon rates to compensate for the lower issuing cost compared to that of Coco bonds with the principal write-down feature. Therefore, the safety level of CoCo bonds (CET1_Spread) may decrease as the CET1 capital may be too costly to hold for the issuing banks, which results in lower preference scores for buyers across the high (75th), medium (50th) and low (25th) percentiles. We also find that CoCo bond buyers in the highest percentile (YTC_SCORE_75 and YTM_SCORE_75) react to the largest number of CoCo bonds 'and issuing banks' characteristics.

Buyers of CoCo bonds with a low safety-adjusted return as indicated by the YTC_SCORE_25 and YTC_SCORE_25 (i.e., in the 25th percentile) respond to fewer CoCo bond, issuing bank and economic condition factors than buyers in the medium (50th) and high (75th) percentiles - they are mainly concerned about the return (CPN) on CoCo bonds rather than their potential risks and the issuing bank's financial situation. Thus, they can be classified as growth investors.

CoCo bond buyers with a medium safety-adjusted return of YTC_SCORE_50 and YTM_SCORE_50 (i.e., in the 50th percentile) are the most sensitive ones to the maturity (MAT) factor. While their preference responses to the CoCo bond and issuing bank's characteristics are generally less pronounced than those of the buyers in the high and low percentiles, their decision to buy CoCo bonds is mainly based on their perpetual maturity feature $\left(\mathrm{H}_{5}\right)$ - they prefer to hold CoCo bond for a long time and can be seen as value investors.

Buyers with a high safety-adjusted return (in the 75th percentile) are those paying most attention to the CoCo bonds and issuing banks' financial characteristics. In particular, they prefer the issuing banks to be overvalued, large sized ones but with low risks. An increase in CoCo bond issuance may dilute the shareholders' ownership when conversion occurs, which is a negative signal to investors in general. However, when this is accompanied by an increase in the issuing bank's return on equity $($ AMT $\times$ ROE), investors perceive this as a safer financial position of the bank since an increase in the return on equity also indicates higher risk. These buyers are also sensitive to the inflation level in the economy (CPI) which could negatively affect their real purchasing power as CoCo bond investors. Overall, buyers in the high percentile are relatively active investors who strongly monitor many CoCo bonds' and issuing bank's conditions along with the economic situation.

Table 3

CoCo bond preference score analysis. The following tables present the multinomial logistic regression results with CoCo bond buyer's preference scores YTM_SCORE (Panel A) and YTC_SCORE (Panel B) as dependent variables and CoCo bond (between 1 April 2010 and 18 December 2019), its issuing bank and economic characteristics as independent variables. The CoCo bonds' characteristics considered are: coupon (CPN in \%), maturity (MAT), amount issued (AMT in US \$), trigger level (TRI in \%), conversion (CON) and credit rating (CRD). The CoCo bond issuing firm characteristics included are: return on common equity (ROE), firm size (SIZE), price-to-book value ratio (P/B) and total regulatory capital to risk-weighted asset (TRC/RWA). The economic control variables are real GDP growth (RGDP in yearly percentage change) and consumer price index (CPI in yearly percentage change). For our dependent variables, we use YTC_SCORE $(=$ Bid_YTC $\times($ CET1_Ratio - TRI $))$ and YTM_SCORE $\left(=B i d \_Y T M \times\left(C E T 1 \_R a t i o-T R I\right)\right)$ as for our CoCo bond investors' preference score measures; these are equal to one, two and three if greater or equal to the 25th (YTC_SCORE_25 and YTM_SCORE_25), 50th (YTC_SCORE_50 and YTM_SCORE_50) and 75th (YTC_SCORE_75 and YTM_SCORE_75) percentiles of the overall CoCo bonds within each year, respectively, and zero otherwise. We show the marginal response of buyer's preference probabilities $\Delta P_{\text {buyers }}^{Y T C}$ and $\Delta P_{\text {buyers }}^{Y T M}$ corresponding to each independent and dependent variable. We report $\chi^{2}$ and $R^{2}$ as our goodness-of-fit measures and $N$ as the total number of observations. The standard errors are in parentheses. ${ }^{*}$ stands for significance at the $10 \%$ level, ${ }^{* *}$ at the $5 \%$ level and ${ }^{* * *}$ at the $1 \%$ level.

\begin{tabular}{|c|c|c|c|c|c|c|}
\hline \multirow[t]{3}{*}{ Panel A. YTC_SCORE } & \multirow{2}{*}{\multicolumn{2}{|c|}{ YTC_SCORE_25 }} & \multirow{2}{*}{\multicolumn{2}{|c|}{ YTC_SCORE_50 }} & \multirow{2}{*}{\multicolumn{2}{|c|}{ YTC_SCORE_75 }} \\
\hline & & & & & & \\
\hline & Coeff. & $\Delta P_{\text {buyers }}^{Y T C}$ & Coeff. & $\Delta P_{\text {buyers }}^{Y T C}$ & Coeff. & $\Delta P_{\text {buyers }}^{Y T C}$ \\
\hline (Intercept) & $\begin{array}{l}-12.188^{* * *} \\
(-12.351)\end{array}$ & & $\begin{array}{l}-21.854^{* * *} \\
(-37.496)\end{array}$ & & $\begin{array}{l}-4.501 \\
(-5.721)\end{array}$ & \\
\hline $\mathrm{CPN}$ & $\begin{array}{l}0.652 * * * \\
(4.173)\end{array}$ & $0.271^{* * *}$ & $\begin{array}{l}0.628 * * * \\
(4.288)\end{array}$ & $0.264^{* * *}$ & $\begin{array}{l}0.83^{* * *} \\
(6.262)\end{array}$ & $0.324^{* * *}$ \\
\hline $\mathrm{CPN} \times \mathrm{TRI}$ & $\begin{array}{l}0.157 \\
(1.182)\end{array}$ & 0.277 & $\begin{array}{l}0.01 \\
(0.062)\end{array}$ & 0.239 & $\begin{array}{l}0.038 \\
(0.362)\end{array}$ & 0.246 \\
\hline $\mathrm{CPN} \times \mathrm{CON}$ & $\begin{array}{l}-0.564^{*} \\
(-1.929)\end{array}$ & 0.185* & $\begin{array}{l}-0.291 \\
(-0.911)\end{array}$ & 0.243 & $\begin{array}{l}-0.269 \\
(-1.108)\end{array}$ & 0.248 \\
\hline $\mathrm{CPN} \times \mathrm{CRD}$ & $\begin{array}{l}-0.222{ }^{* * *} \\
(-2.727)\end{array}$ & $0.238^{* * *}$ & $\begin{array}{l}-0.204 * * * \\
(-2.692)\end{array}$ & $0.242^{* * *}$ & $\begin{array}{l}-0.291 * * \\
(-3.982)\end{array}$ & $0.222^{* * *}$ \\
\hline TRI & $\begin{array}{l}-0.18 \\
(-0.714)\end{array}$ & 0.292 & $\begin{array}{l}-0.835^{* * *} \\
(-3.102)\end{array}$ & $0.152^{* * *}$ & $\begin{array}{l}-0.521^{* *} \\
(-2.364)\end{array}$ & $0.208^{* *}$ \\
\hline $\mathrm{TRI} \times \mathrm{CON}$ & $\begin{array}{l}-0.133 \\
(-0.291)\end{array}$ & 0.237 & $\begin{array}{l}-0.238 \\
(-0.432)\end{array}$ & 0.214 & $\begin{array}{l}0.025 \\
(0.058)\end{array}$ & 0.278 \\
\hline CON & $\begin{array}{l}-0.828 \\
(-1.444)\end{array}$ & 0.228 & $\begin{array}{l}-1.248^{* *} \\
(-2.091)\end{array}$ & $0.150^{* *}$ & $\begin{array}{l}-1.651^{* * *} \\
(-3.375)\end{array}$ & $0.100^{* * *}$ \\
\hline
\end{tabular}


Table 3 (continued)

\begin{tabular}{|c|c|c|c|c|c|c|}
\hline \multirow[t]{2}{*}{ Panel A. YTC_SCORE } & \multicolumn{2}{|c|}{ YTC_SCORE_25 } & \multicolumn{2}{|c|}{ YTC_SCORE_50 } & \multicolumn{2}{|c|}{ YTC_SCORE_75 } \\
\hline & Coeff. & $\Delta P_{\text {buyers }}^{Y T C}$ & Coeff. & $\Delta P_{\text {buyers }}^{Y T C}$ & Coeff. & $\Delta P_{\text {buyers }}^{Y T C}$ \\
\hline CRD & $\begin{array}{l}-0.03 \\
(-0.198)\end{array}$ & 0.242 & $\begin{array}{l}-0.207 \\
(-1.412)\end{array}$ & 0.202 & $\begin{array}{l}0.211 \\
(1.597)\end{array}$ & 0.307 \\
\hline MAT & $\begin{array}{l}0.599 \\
(0.686)\end{array}$ & 0.000 & $\begin{array}{l}\text { 12.556 }^{* * *} \\
(21.536)\end{array}$ & $1.000^{* * *}$ & $\begin{array}{l}1.137^{*} \\
(1.787)\end{array}$ & $0.000^{*}$ \\
\hline AMT & $\begin{array}{l}0.365 \\
(1.084)\end{array}$ & 0.390 & $\begin{array}{l}-0.322 \\
(-1.2)\end{array}$ & 0.196 & $\begin{array}{l}-0.643^{* * *} \\
(-2.855)\end{array}$ & $0.142^{* * *}$ \\
\hline $\mathrm{AMT} \times \mathrm{ROE}$ & $\begin{array}{l}0.028 \\
(1.397)\end{array}$ & 0.251 & $\begin{array}{l}0.025 \\
(1.337)\end{array}$ & 0.250 & $\begin{array}{l}0.038^{* *} \\
(2.33)\end{array}$ & $0.254^{* *}$ \\
\hline $\mathrm{AMT} \times \mathrm{P} / \mathrm{B}$ & $\begin{array}{l}-0.233^{*} \\
(-1.826)\end{array}$ & $0.217^{*}$ & $\begin{array}{l}-0.036 \\
(-0.348)\end{array}$ & 0.264 & $\begin{array}{l}-0.106 \\
(-1.146)\end{array}$ & 0.246 \\
\hline CDS & $\begin{array}{l}-0.412^{*} \\
(-1.924)\end{array}$ & $0.229^{*}$ & $\begin{array}{l}-0.4499^{* *} \\
(-2.284)\end{array}$ & $0.220^{* *}$ & $\begin{array}{l}-0.521 * * * \\
(-2.959)\end{array}$ & $0.205^{* * *}$ \\
\hline ROE & $\begin{array}{l}0.002 \\
(0.052)\end{array}$ & 0.248 & $\begin{array}{l}-0.005 \\
(-0.133)\end{array}$ & 0.246 & $\begin{array}{l}0.049 \\
(1.425)\end{array}$ & 0.260 \\
\hline $\mathrm{P} / \mathrm{B}$ & $\begin{array}{l}0.52^{*} \\
(1.711)\end{array}$ & $0.274^{*}$ & $\begin{array}{l}0.457^{*} \\
(1.71)\end{array}$ & $0.257^{*}$ & $\begin{array}{l}0.63^{* * *} \\
(2.65)\end{array}$ & $0.306^{* * *}$ \\
\hline SIZE & $\begin{array}{l}0.209 \\
(1.549)\end{array}$ & 0.288 & $\begin{array}{l}-0.116 \\
(-0.956)\end{array}$ & 0.208 & $\begin{array}{l}0.147 \\
(1.602)\end{array}$ & 0.271 \\
\hline TRC/RWA & $\begin{array}{l}-0.088 \\
(-1.283)\end{array}$ & 0.224 & $\begin{array}{l}0.017 \\
(0.273)\end{array}$ & 0.249 & $\begin{array}{l}0.139 * * * \\
(2.698)\end{array}$ & $0.281^{* * *}$ \\
\hline RGDP & $\begin{array}{l}-0.026 \\
(-0.174)\end{array}$ & 0.249 & $\begin{array}{l}0.032 \\
(0.223)\end{array}$ & 0.264 & $\begin{array}{l}-0.094 \\
(-0.85)\end{array}$ & 0.232 \\
\hline CPI & $\begin{array}{l}0.054 \\
(0.291)\end{array}$ & 0.262 & $\begin{array}{l}0.171 \\
(0.889)\end{array}$ & 0.294 & $\begin{array}{l}-0.236 \\
(-1.54)\end{array}$ & 0.196 \\
\hline $\begin{array}{l}\text { Year Fixed Effect } \\
\text { Region Fixed Effect } \\
\chi^{2} \\
\text { Pseudo- } R^{2}\end{array}$ & $\begin{array}{l}\text { Yes } \\
\text { Yes } \\
\mathbf{1 7 2 7 . 2 8}^{* * *} \\
0.79\end{array}$ & & & & & \\
\hline \multicolumn{7}{|l|}{ Panel B. YTM_SCORE } \\
\hline & \multicolumn{2}{|c|}{ YTM_SCORE_25 } & \multicolumn{2}{|c|}{ YTM_SCORE_50 } & \multicolumn{2}{|c|}{ YTM_SCORE_75 } \\
\hline & Coeff. & $\Delta P_{\text {buyers }}^{Y T M}$ & Coeff. & $\Delta P_{\text {buyers }}^{Y T M}$ & Coeff. & $\Delta P_{\text {buyers }}^{Y T M}$ \\
\hline (Intercept) & $\begin{array}{l}-15.856 * * * \\
(-15.485)\end{array}$ & & $\begin{array}{l}-22.902^{* * *} \\
(-39.91)\end{array}$ & & $\begin{array}{l}-6.079^{* * *} \\
(-7.335)\end{array}$ & \\
\hline CPN & $\begin{array}{l}0.523^{* * *} \\
(3.234)\end{array}$ & $0.239^{* * *}$ & $\begin{array}{l}0.699 \\
(4.565)\end{array}$ & $0.284^{* * *}$ & $\begin{array}{l}0.866^{* * *} \\
(6.26)\end{array}$ & $0.336^{* * *}$ \\
\hline $\mathrm{CPN} \times \mathrm{TRI}$ & $\begin{array}{l}0.239 \\
(1.531)\end{array}$ & 0.298 & $\begin{array}{l}-0.047 \\
(-0.293)\end{array}$ & 0.224 & $\begin{array}{l}0.04 \\
(0.374)\end{array}$ & 0.244 \\
\hline $\mathrm{CPN} \times \mathrm{CON}$ & $\begin{array}{l}-0.688^{* *} \\
(-2.093)\end{array}$ & $0.173^{* *}$ & $\begin{array}{l}-0.299 \\
(-0.951)\end{array}$ & 0.256 & $\begin{array}{l}-0.419^{*} \\
(-1.701)\end{array}$ & $0.227^{*}$ \\
\hline $\mathrm{CPN} \times \mathrm{CRD}$ & $\begin{array}{l}-0.194^{* * *} \\
(-2.42)\end{array}$ & $0.244^{* * *}$ & $\begin{array}{l}-0.209^{* * *} \\
(-2.712)\end{array}$ & $0.240^{* * *}$ & $\begin{array}{l}-0.298^{* * *} \\
(-4.098)\end{array}$ & $0.220^{* * *}$ \\
\hline TRI & $\begin{array}{l}-0.144 \\
(-0.538)\end{array}$ & 0.313 & $\begin{array}{l}-1.013^{* * *} \\
(-3.646)\end{array}$ & $0.131^{* * *}$ & $\begin{array}{l}-0.617^{* * *} \\
(-2.65)\end{array}$ & $0.195^{* * *}$ \\
\hline $\mathrm{TRI} \times \mathrm{CON}$ & $\begin{array}{l}0.311 \\
(0.641)\end{array}$ & 0.315 & $\begin{array}{l}-0.229 \\
(-0.421)\end{array}$ & 0.184 & $\begin{array}{l}0.158 \\
(0.349)\end{array}$ & 0.270 \\
\hline
\end{tabular}




\begin{tabular}{|c|c|c|c|c|c|c|}
\hline $\mathrm{CON}$ & $\begin{array}{l}-1.392 * * \\
(-2.248)\end{array}$ & $0.135^{* *}$ & $\begin{array}{l}-0.857 \\
(-1.467)\end{array}$ & 0.230 & $\begin{array}{l}-1.747^{* * *} \\
(-3.488)\end{array}$ & $0.094^{* * *}$ \\
\hline CRD & $\begin{array}{l}0.12 \\
(0.803)\end{array}$ & 0.251 & $\begin{array}{l}0.006 \\
(0.04)\end{array}$ & 0.224 & $\begin{array}{l}0.302{ }^{* *} \\
(2.282)\end{array}$ & $0.302^{* *}$ \\
\hline MAT & $\begin{array}{l}1.465 \\
(1.563)\end{array}$ & 0.000 & $\begin{array}{l}\text { 12.079*** }^{* *} \\
(21.039)\end{array}$ & $1.000^{* * *}$ & $\begin{array}{l}1.342^{* *} \\
(2.056)\end{array}$ & $0.000^{* *}$ \\
\hline AMT & $\begin{array}{l}0.149 \\
(0.458)\end{array}$ & 0.349 & $\begin{array}{l}-0.393 \\
(-1.424)\end{array}$ & 0.203 & $\begin{array}{l}-0.713^{* * *} \\
(-3.008)\end{array}$ & $0.147^{* * *}$ \\
\hline AMT $\times$ ROE & $\begin{array}{l}0.032 \\
(1.472)\end{array}$ & 0.253 & $\begin{array}{l}0.01 \\
(0.535)\end{array}$ & 0.248 & $\begin{array}{l}0.034^{* *} \\
(2.011)\end{array}$ & $0.254^{* *}$ \\
\hline $\mathrm{AMT} \times \mathrm{P} / \mathrm{B}$ & $\begin{array}{l}-0.111 \\
(-0.868)\end{array}$ & 0.232 & $\begin{array}{l}0.04 \\
(0.378)\end{array}$ & 0.270 & $\begin{array}{l}-0.079 \\
(-0.856)\end{array}$ & 0.239 \\
\hline CDS & $\begin{array}{l}-0.226 \\
(-1.059)\end{array}$ & 0.251 & $\begin{array}{l}-0.351^{*} \\
(-1.728)\end{array}$ & $0.222^{*}$ & $\begin{array}{l}-0.4^{* *} \\
(-2.203)\end{array}$ & $0.211^{* *}$ \\
\hline ROE & $\begin{array}{l}-0.007 \\
(-0.155)\end{array}$ & 0.248 & $\begin{array}{l}-0.038 \\
(-0.98)\end{array}$ & 0.240 & $\begin{array}{l}0.049 \\
(1.379)\end{array}$ & 0.262 \\
\hline $\mathrm{P} / \mathrm{B}$ & $\begin{array}{l}0.378 \\
(1.265)\end{array}$ & 0.252 & $\begin{array}{l}0.516^{*} \\
(1.936)\end{array}$ & $0.289^{*}$ & $\begin{array}{l}0.51^{* *} \\
(2.161)\end{array}$ & $0.287^{* *}$ \\
\hline SIZE & $\begin{array}{l}0.223 \\
(1.653)\end{array}$ & 0.274 & $\begin{array}{l}0.056 \\
(0.452)\end{array}$ & 0.232 & $\begin{array}{l}0.221 * * \\
(2.215)\end{array}$ & $0.274^{* *}$ \\
\hline TRC/RWA & $\begin{array}{l}-0.046 \\
(-0.641)\end{array}$ & 0.226 & $\begin{array}{l}0.083 \\
(1.303)\end{array}$ & 0.257 & $\begin{array}{l}0.172 * * * \\
(3.159)\end{array}$ & $0.281^{* * *}$ \\
\hline RGDP & $\begin{array}{l}-0.043 \\
(-0.265)\end{array}$ & 0.249 & $\begin{array}{l}0.002 \\
(0.017)\end{array}$ & 0.260 & $\begin{array}{l}-0.113 \\
(-0.978)\end{array}$ & 0.232 \\
\hline CPI & $\begin{array}{l}-0.111 \\
(-0.56)\end{array}$ & 0.256 & $\begin{array}{l}-0.062 \\
(-0.317)\end{array}$ & 0.269 & $\begin{array}{l}-0.422 * * * \\
(-2.609)\end{array}$ & $0.188^{* * *}$ \\
\hline Year Fixed Effect & Yes & & & & & \\
\hline Region Fixed Effect & Yes & & & & & \\
\hline$\chi^{2}$ & $\mathbf{1 7 4 5 . 2 6}^{* * *}$ & & & & & \\
\hline
\end{tabular}

\subsubsection{Marginal preference responses of CoCo bond buyers and sellers}

In Table 4, we calculate and compare the marginal preference response of CoCo bond buyers $\left(\Delta P_{\text {buyers }}^{Y T C}\right.$ and $\left.\Delta P_{\text {buyers }}^{Y T M}\right)$ and sellers ( $\Delta P_{\text {sellers }}^{Y T C}$ and $\Delta P_{\text {sellers }}^{Y T M}$ ) based on the conditional probability measures from Eqs. (4) and (5). We show the marginal preference responses of both buyers and sellers in Panel A and $\mathrm{C}^{4}$ and report on the factors affecting them in Panel B and D. We find that the marginal response is stronger for sellers for most of the factors except maturity at the 50th percentile. This indicates that $\mathrm{CoCo}$ bonds are more strongly driven by the sellers' desire to protect themselves against bankruptcy and satisfy financial regulations than buyers are by their aim to increase their financial returns from this fixed-income security. The buyers' marginal preference responses outweigh those of the sellers in the case of CoCo bonds with perpetual maturity and a medium level (YTC_SCORE_50 and YTC_SCORE_50) safety-adjusted return profile. In other words, buyers regard these CoCo bonds as value investment instruments to hold for a long period over which to receive high coupon payments.

\subsubsection{Global marginal preference responses of CoCo bond buyers and sellers}

We analyse for each country the CoCo bond average preference responses to the the factors significant at the $5 \%$ level according to Table 3 and 4 by estimating Eqs. (8) and (9) which include country-specific CoCo bond market competitiveness. We report country (Table 5) and factor (Table 6) averages for buyers and sellers in the 25 th, 50th and 75th percentiles. The global marginal preference responses only show the magnitude of the effect, not its direction, which is the opposite for buyers vis-à-vis sellers.

We find that in the main European countries (e.g., France, Germany, Italy, Netherlands, Russia, Spain, Switzerland and UK), Brazil, Mexico and a few of the main Far East countries (China and Japan) there are significant responses to the CoCo bonds' and issuing banks' characteristics. The UK and China are the two countries with the strongest responses from both buyers and sellers (see Table 5 and Appendix F). Also, global buyers and sellers of CoCo bonds with the high safety adjusted

\footnotetext{
${ }^{4}$ Please note that the conditional probabilities for buyers in panel A and C in Table 4 are the same as those in Table 3.
} 
Table 4

Marginal preference responses between CoCo bond buyers and sellers. The following tables show the marginal preference responses between buyers and sellers of CoCo bonds in YTC_SCORE (Panel A and B) and YTM_SCORE (Panel C and D). We show the marginal preference response figures (Panel A and C) and report the dominating party, either buyers or sellers for each significant factor based on their relative marginal preference response strengths (Panel B and D). We use CoCo bond investors' preference score measures; these are equal to one, two and three if greater or equal to the 25th (YTC_SCORE_25 and YTM_SCORE_25), 50th (YTC_SCORE_50 and YTM_SCORE_50) and 75th (YTC_SCORE_75 and YTM_SCORE_75) percentiles of the overall CoCo bonds, respectively, and zero otherwise. We show the marginal response of buyers $\left(\Delta P_{\text {buyers }}^{Y T C}\right.$ and $\left.\Delta P_{\text {buyers }}^{Y T M}\right)$ and sellers' $\left(\Delta P_{\text {sellers }}^{Y T C}\right.$ and $\left.\Delta P_{\text {sellers }}^{Y T M}\right)$ preference probabilities corresponding to each independent and dependent variables as in our Table $3 .{ }^{*}$ stands for significance at the $10 \%$ level, ${ }^{* *}$ at the $5 \%$ level and ${ }^{* * *}$ represents at the $1 \%$ level.

\begin{tabular}{|c|c|c|c|c|c|c|}
\hline \multicolumn{7}{|c|}{ Panel A. $\triangle Y$ YTC_SCORE } \\
\hline & \multicolumn{2}{|c|}{ YTC_SCORE_25 } & \multicolumn{2}{|c|}{ YTC_SCORE_50 } & \multicolumn{2}{|c|}{ YTC_SCORE_75 } \\
\hline & $\Delta P_{\text {buyers }}^{Y T C}$ & $\Delta P_{\text {sellers }}^{Y T C}$ & $\Delta P_{\text {buyers }}^{Y T C}$ & $\Delta P_{\text {sellers }}^{Y T C}$ & $\Delta P_{\text {buyers }}^{Y T C}$ & $\Delta P_{\text {sellers }}^{Y T C}$ \\
\hline CPN & $0.271^{* * *}$ & $0.729^{* * *}$ & $0.264^{* * *}$ & $0.736^{* * *}$ & $0.324^{* * *}$ & $0.676^{* * *}$ \\
\hline $\mathrm{CPN} \times \mathrm{TRI}$ & 0.277 & 0.723 & 0.239 & 0.761 & 0.246 & 0.754 \\
\hline $\mathrm{CPN} \times \mathrm{CON}$ & $0.185^{*}$ & $0.815^{*}$ & 0.243 & 0.757 & 0.248 & 0.752 \\
\hline $\mathrm{CPN} \times \mathrm{CRD}$ & $0.238^{* * *}$ & $0.762^{* * *}$ & $0.242^{* * *}$ & $0.758^{* * *}$ & $0.222^{* * *}$ & $0.778^{* * *}$ \\
\hline TRI & 0.292 & 0.708 & $0.152^{* * *}$ & $0.848^{* * *}$ & $0.208^{* *}$ & $0.792^{* *}$ \\
\hline $\mathrm{TRI} \times \mathrm{CON}$ & 0.237 & 0.763 & 0.214 & 0.786 & 0.278 & 0.722 \\
\hline $\mathrm{CON}$ & 0.228 & 0.772 & $0.150^{* *}$ & $0.850^{* *}$ & $0.100^{* * *}$ & $0.900^{* * *}$ \\
\hline CRD & 0.242 & 0.758 & 0.202 & 0.798 & 0.307 & 0.693 \\
\hline MAT & 0.000 & 1.000 & $1.000^{* * *}$ & $0.000^{* * *}$ & $0.000^{*}$ & $1.000^{*}$ \\
\hline AMT & 0.390 & 0.610 & 0.196 & 0.804 & $0.142^{* * *}$ & $0.858^{* * *}$ \\
\hline $\mathrm{AMT} \times \mathrm{ROE}$ & 0.251 & 0.749 & 0.250 & 0.750 & $0.254^{* *}$ & $0.746^{* *}$ \\
\hline $\mathrm{AMT} \times \mathrm{P} / \mathrm{B}$ & 0.217* & $0.783^{*}$ & 0.264 & 0.736 & 0.246 & 0.754 \\
\hline CDS & $0.229 *$ & $0.771^{*}$ & $0.220^{* *}$ & $0.780^{* *}$ & $0.205^{* * *}$ & $0.795^{* * *}$ \\
\hline ROE & 0.248 & 0.752 & 0.246 & 0.754 & 0.260 & 0.740 \\
\hline $\mathrm{P} / \mathrm{B}$ & $0.274^{*}$ & $0.726^{*}$ & $0.257^{*}$ & $0.743^{*}$ & $0.306^{* * *}$ & $0.694^{* * *}$ \\
\hline SIZE & 0.288 & 0.712 & 0.208 & 0.792 & 0.271 & 0.729 \\
\hline TRC/RWA & 0.224 & 0.776 & 0.249 & 0.751 & $0.281^{* * *}$ & $0.719^{* * *}$ \\
\hline RGDP & 0.249 & 0.751 & 0.264 & 0.736 & 0.232 & 0.768 \\
\hline CPI & 0.262 & 0.738 & 0.294 & 0.706 & 0.196 & 0.804 \\
\hline
\end{tabular}

Panel B. Relative strength dominance between buyers and sellers in $\triangle \mathrm{YTC}$ SCORE

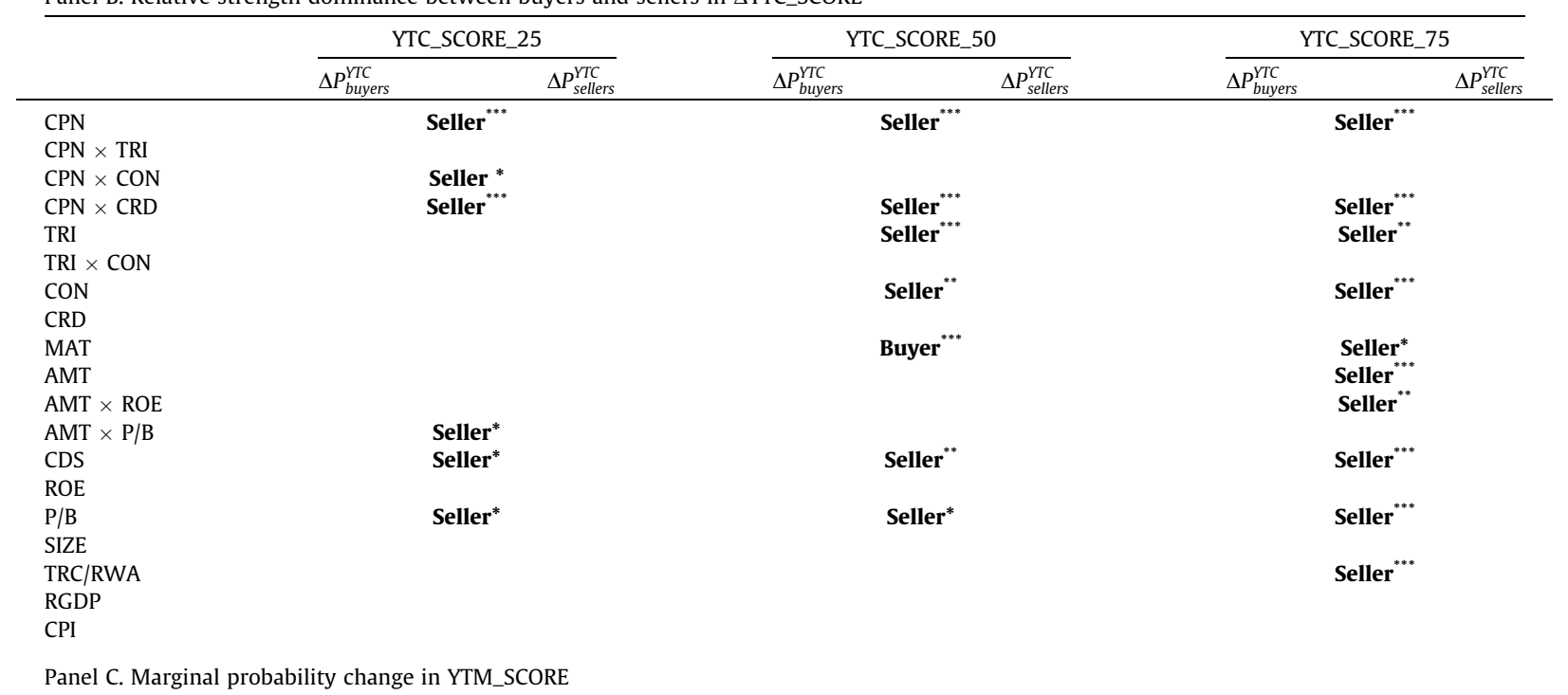

\begin{tabular}{|c|c|c|c|c|c|c|}
\hline & \multicolumn{2}{|c|}{ YTM_SCORE_25 } & \multicolumn{2}{|c|}{ YTM_SCORE_50 } & \multicolumn{2}{|c|}{ YTM_SCORE_75 } \\
\hline & $\Delta P_{\text {buyers }}^{Y T M}$ & $\Delta P_{\text {sellers }}^{Y T M}$ & $\Delta P_{\text {buyers }}^{Y T M}$ & $\Delta P_{\text {sellers }}^{Y T M}$ & $\Delta P_{\text {buyers }}^{Y T M}$ & $\Delta P_{\text {sellers }}^{Y T M}$ \\
\hline $\mathrm{CPN}$ & $0.239^{* * *}$ & $0.761^{* * *}$ & $0.284^{* * *}$ & $0.716^{* * *}$ & $0.336^{* * *}$ & $0.664^{* * *}$ \\
\hline $\mathrm{CPN} \times \mathrm{TRI}$ & 0.298 & 0.702 & 0.224 & 0.776 & 0.244 & 0.756 \\
\hline $\mathrm{CPN} \times \mathrm{CON}$ & $0.173^{* *}$ & $0.827^{* *}$ & 0.256 & 0.744 & $0.227^{*}$ & 0.773* \\
\hline $\mathrm{CPN} \times \mathrm{CRD}$ & $0.244^{* *}$ & $0.756^{* *}$ & $0.240^{* * *}$ & $0.760^{* * *}$ & $0.220^{* * *}$ & $0.780^{* * *}$ \\
\hline TRI & 0.313 & 0.687 & $0.131^{* * *}$ & $0.869^{* * *}$ & $0.195^{* * *}$ & $0.805^{* * *}$ \\
\hline $\mathrm{TRI} \times \mathrm{CON}$ & 0.315 & 0.685 & 0.184 & 0.816 & 0.270 & 0.730 \\
\hline CON & $0.135^{* *}$ & $0.865^{* *}$ & 0.230 & 0.770 & $0.094^{* * *}$ & $0.906^{* * *}$ \\
\hline CRD & 0.251 & 0.749 & 0.224 & 0.776 & $0.302^{* *}$ & $0.698^{* *}$ \\
\hline MAT & 0.000 & 1.000 & $1.000^{* * *}$ & $0.000^{* * *}$ & $0.000^{* *}$ & $1.000^{* *}$ \\
\hline AMT & 0.349 & 0.651 & 0.203 & 0.797 & $0.147^{* * *}$ & $0.853^{* * *}$ \\
\hline
\end{tabular}




$\begin{array}{llll}\text { AMT } \times \text { ROE } & 0.253 & 0.747 & 0.248 \\ \text { AMT } \times \text { P/B } & 0.232 & 0.768 & 0.270 \\ \text { CDS } & 0.251 & 0.749 & \mathbf{0 . 2 2 2}^{*} \\ \text { ROE } & 0.248 & 0.752 & 0.240 \\ \text { P/B } & 0.252 & 0.748 & \mathbf{0 . 2 8 9}^{*} \\ \text { SIZE } & 0.274 & 0.726 & 0.232 \\ \text { TRC/RWA } & 0.226 & 0.774 & 0.257 \\ \text { RGDP } & 0.249 & 0.751 & 0.260 \\ \text { CPI } & 0.256 & 0.744 & 0.269\end{array}$

Panel D. Relative strength dominance between buyers and sellers in $\triangle Y$ YTM_SCORE

\begin{tabular}{|c|c|c|c|c|c|c|c|}
\hline & \multicolumn{2}{|c|}{ YTM_SCORE_25 } & \multicolumn{2}{|c|}{ YTM_SCORE_50 } & \multicolumn{3}{|c|}{ YTM_SCORE_75 } \\
\hline & $\Delta P_{\text {buyers }}^{Y T M}$ & $\Delta P_{\text {sellers }}^{Y T M}$ & $\Delta P_{\text {buyers }}^{Y T M}$ & $\Delta P_{\text {sellers }}^{Y T M}$ & $\Delta P_{\text {buyers }}^{Y T M}$ & & $\Delta P_{\text {sellers }}^{Y T M}$ \\
\hline $\mathrm{CPN}$ & \multicolumn{2}{|r|}{ Seller $^{* * *}$} & \multicolumn{2}{|c|}{ Seller $^{* * *}$} & \multicolumn{3}{|c|}{ Seller $^{* * *}$} \\
\hline \multicolumn{8}{|l|}{$\mathrm{CPN} \times \mathrm{TRI}$} \\
\hline $\mathrm{CPN} \times \mathrm{CON}$ & \multirow{2}{*}{\multicolumn{2}{|c|}{ Seller ${ }^{* *}$}} & \multirow{2}{*}{\multicolumn{2}{|c|}{ Seller $^{* * *}$}} & \multicolumn{3}{|c|}{ Seller* } \\
\hline $\mathrm{CPN} \times \mathrm{CRD}$ & & & & & \multirow{2}{*}{\multicolumn{3}{|c|}{$\begin{array}{l}\text { Seller }^{* * *} \\
\text { Seller }\end{array}$}} \\
\hline TRI & & & \multicolumn{2}{|c|}{ Seller ${ }^{* * *}$} & & & \\
\hline \multicolumn{8}{|l|}{$\mathrm{TRI} \times \mathrm{CON}$} \\
\hline CON & & Seller ${ }^{* *}$ & & & \multicolumn{3}{|c|}{ Seller $^{* * *}$} \\
\hline CRD & & & \multicolumn{2}{|c|}{ Buyer $^{* * *}$} & \multicolumn{3}{|c|}{ Seller ${ }^{* *}$} \\
\hline MAT & & & & & \multicolumn{3}{|c|}{ Seller ${ }^{* *}$} \\
\hline AMT & & & & & \multirow{2}{*}{\multicolumn{3}{|c|}{ Seller ${ }_{* * *}^{* *}$}} \\
\hline $\mathrm{AMT} \times \mathrm{ROE}$ & & & & & \multicolumn{2}{|r|}{ Seller ${ }^{* *}$} & \\
\hline \multicolumn{8}{|l|}{ AMT $\times \mathrm{P} / \mathrm{B}$} \\
\hline CDS & & & & & \multicolumn{3}{|c|}{ Seller ${ }^{* *}$} \\
\hline \multicolumn{8}{|l|}{ ROE } \\
\hline $\mathrm{P} / \mathrm{B}$ & & & \multicolumn{2}{|c|}{ Seller* } & \multicolumn{3}{|c|}{ Seller ${ }^{* *}$} \\
\hline SIZE & & & & & \multicolumn{3}{|c|}{ Seller ${ }^{* *}$} \\
\hline TRC/RWA & & & & & \multirow{2}{*}{\multicolumn{3}{|c|}{ Seller $^{* * *}$}} \\
\hline \multicolumn{7}{|l|}{ RGDP } & \\
\hline CPI & & & & & \multicolumn{3}{|c|}{ Seller $^{* * *}$} \\
\hline
\end{tabular}

Table 5

Country average CoCo bond's global buyer and seller's preference scores with incremental factor change. The following tables present the incremental change in CoCo bond's global buyer (Panel A) and seller's (Panel B) country average preference scores based on the 25th (SCORE_25), 50th (SCORE_50) and 75th (SCORE_75) percentile benchmarks of YTC_SCORE and YTM_SCORE. The tables below summarise the calculated country average preference scores in Appendices B-E.

\begin{tabular}{|c|c|c|c|c|c|c|}
\hline \multicolumn{7}{|c|}{ Panel A. Global buyer's country average preference scores } \\
\hline \multirow[t]{2}{*}{ Country } & \multicolumn{3}{|l|}{$\Delta \mathrm{YTC}$} & \multicolumn{3}{|l|}{$\Delta \mathrm{YTM}$} \\
\hline & SCORE_25 & SCORE_50 & SCORE_75 & SCORE_25 & SCORE_50 & SCORE_75 \\
\hline Australia & $0.90 \%$ & $1.89 \%$ & $0.98 \%$ & $1.16 \%$ & $1.54 \%$ & $1.03 \%$ \\
\hline Austria & $0.82 \%$ & $1.72 \%$ & $0.89 \%$ & $1.06 \%$ & $1.40 \%$ & $0.94 \%$ \\
\hline Belgium & $0.63 \%$ & $1.32 \%$ & $0.69 \%$ & $0.81 \%$ & $1.08 \%$ & $0.73 \%$ \\
\hline Brazil & $11.22 \%$ & $23.51 \%$ & $12.18 \%$ & $14.46 \%$ & $19.21 \%$ & $12.89 \%$ \\
\hline China & $258.74 \%$ & $542.14 \%$ & $280.92 \%$ & $333.30 \%$ & $442.85 \%$ & $297.21 \%$ \\
\hline Colombia & $0.07 \%$ & $0.15 \%$ & $0.08 \%$ & $0.09 \%$ & $0.12 \%$ & $0.08 \%$ \\
\hline Croatia & $0.00 \%$ & $0.00 \%$ & $0.00 \%$ & $0.00 \%$ & $0.00 \%$ & $0.00 \%$ \\
\hline Cyprus & $0.05 \%$ & $0.10 \%$ & $0.05 \%$ & $0.06 \%$ & $0.09 \%$ & $0.06 \%$ \\
\hline Czech & $0.01 \%$ & $0.02 \%$ & $0.01 \%$ & $0.01 \%$ & $0.02 \%$ & $0.01 \%$ \\
\hline Denmark & $1.73 \%$ & $3.63 \%$ & $1.88 \%$ & $2.23 \%$ & $2.96 \%$ & $1.99 \%$ \\
\hline Estonia & $0.00 \%$ & $0.00 \%$ & $0.00 \%$ & $0.00 \%$ & $0.00 \%$ & $0.00 \%$ \\
\hline Finland & $1.94 \%$ & $4.06 \%$ & $2.10 \%$ & $2.50 \%$ & $3.32 \%$ & $2.22 \%$ \\
\hline France & $58.57 \%$ & $122.73 \%$ & $63.60 \%$ & $75.45 \%$ & $100.26 \%$ & $67.29 \%$ \\
\hline Georgia & $0.03 \%$ & $0.06 \%$ & $0.03 \%$ & $0.04 \%$ & $0.05 \%$ & $0.03 \%$ \\
\hline Germany & $3.17 \%$ & $6.64 \%$ & $3.44 \%$ & $4.08 \%$ & $5.42 \%$ & $3.64 \%$ \\
\hline Hungary & $0.00 \%$ & $0.01 \%$ & $0.00 \%$ & $0.00 \%$ & $0.01 \%$ & $0.00 \%$ \\
\hline India & $1.68 \%$ & $3.52 \%$ & $1.83 \%$ & $2.17 \%$ & $2.88 \%$ & $1.93 \%$ \\
\hline Indonesia & $0.00 \%$ & $0.00 \%$ & $0.00 \%$ & $0.00 \%$ & $0.00 \%$ & $0.00 \%$ \\
\hline Ireland & $0.37 \%$ & $0.77 \%$ & $0.40 \%$ & $0.47 \%$ & $0.63 \%$ & $0.42 \%$ \\
\hline Israel & $0.22 \%$ & $0.46 \%$ & $0.24 \%$ & $0.28 \%$ & $0.37 \%$ & $0.25 \%$ \\
\hline Italy & $7.56 \%$ & $15.85 \%$ & $8.21 \%$ & $9.74 \%$ & $12.94 \%$ & $8.69 \%$ \\
\hline Japan & $23.83 \%$ & $49.93 \%$ & $25.87 \%$ & $30.69 \%$ & $40.78 \%$ & $27.37 \%$ \\
\hline Luxembourg & $0.01 \%$ & $0.02 \%$ & $0.01 \%$ & $0.01 \%$ & $0.02 \%$ & $0.01 \%$ \\
\hline Malaysia & $1.12 \%$ & $2.34 \%$ & $1.21 \%$ & $1.44 \%$ & $1.91 \%$ & $1.28 \%$ \\
\hline Mexico & $6.99 \%$ & $14.65 \%$ & $7.59 \%$ & $9.01 \%$ & $11.97 \%$ & $8.03 \%$ \\
\hline Netherlands & $7.26 \%$ & $15.20 \%$ & $7.88 \%$ & $9.35 \%$ & $12.42 \%$ & $8.34 \%$ \\
\hline New Zealand & $0.00 \%$ & $0.01 \%$ & $0.00 \%$ & $0.00 \%$ & $0.01 \%$ & $0.00 \%$ \\
\hline
\end{tabular}


Table 5 (continued)

\begin{tabular}{|c|c|c|c|c|c|c|}
\hline \multicolumn{7}{|c|}{ Panel A. Global buyer's country average preference scores } \\
\hline \multirow[t]{2}{*}{ Country } & \multicolumn{3}{|l|}{$\Delta \mathrm{YTC}$} & \multicolumn{3}{|l|}{$\Delta \mathrm{YTM}$} \\
\hline & SCORE_25 & SCORE_50 & SCORE_75 & SCORE_25 & SCORE_50 & SCORE_75 \\
\hline Norway & $1.74 \%$ & $3.64 \%$ & $1.88 \%$ & $2.24 \%$ & $2.97 \%$ & $1.99 \%$ \\
\hline Portugal & $0.21 \%$ & $0.44 \%$ & $0.23 \%$ & $0.27 \%$ & $0.36 \%$ & $0.24 \%$ \\
\hline Russia & $13.66 \%$ & $28.61 \%$ & $14.83 \%$ & $17.59 \%$ & $23.37 \%$ & $15.69 \%$ \\
\hline Slovakia & $0.00 \%$ & $0.01 \%$ & $0.00 \%$ & $0.00 \%$ & $0.01 \%$ & $0.00 \%$ \\
\hline South Africa & $0.01 \%$ & $0.02 \%$ & $0.01 \%$ & $0.01 \%$ & $0.02 \%$ & $0.01 \%$ \\
\hline Spain & $20.43 \%$ & $42.81 \%$ & $22.18 \%$ & $26.32 \%$ & $34.97 \%$ & $23.47 \%$ \\
\hline Sweden & $2.05 \%$ & $4.30 \%$ & $2.23 \%$ & $2.64 \%$ & $3.51 \%$ & $2.36 \%$ \\
\hline Switzerland & $83.13 \%$ & $174.18 \%$ & $90.25 \%$ & $107.08 \%$ & $142.28 \%$ & $95.49 \%$ \\
\hline Turkey & $0.07 \%$ & $0.16 \%$ & $0.08 \%$ & $0.10 \%$ & $0.13 \%$ & $0.09 \%$ \\
\hline United Kingdom & $134.78 \%$ & $282.41 \%$ & $146.33 \%$ & $173.62 \%$ & $230.69 \%$ & $154.82 \%$ \\
\hline \multicolumn{7}{|c|}{ Panel B. Global seller's country average preference scores } \\
\hline \multirow[t]{2}{*}{ Country } & \multicolumn{3}{|l|}{$\Delta \mathrm{YTC}$} & \multicolumn{3}{|l|}{$\Delta \mathrm{YTM}$} \\
\hline & SCORE_25 & SCORE_50 & SCORE_75 & SCORE_25 & SCORE_50 & SCORE_75 \\
\hline Australia & $3.66 \%$ & $2.67 \%$ & $3.58 \%$ & $3.40 \%$ & $3.02 \%$ & $3.53 \%$ \\
\hline Austria & $3.33 \%$ & $2.43 \%$ & $3.26 \%$ & $3.10 \%$ & $2.75 \%$ & $3.21 \%$ \\
\hline Belgium & $2.57 \%$ & $1.88 \%$ & $2.51 \%$ & $2.39 \%$ & $2.12 \%$ & $2.47 \%$ \\
\hline Brazil & $45.58 \%$ & $33.29 \%$ & $44.62 \%$ & $42.35 \%$ & $37.60 \%$ & $43.92 \%$ \\
\hline China & $1051.04 \%$ & $767.63 \%$ & $1028.86 \%$ & $976.47 \%$ & $866.92 \%$ & $1012.56 \%$ \\
\hline Colombia & $0.30 \%$ & $0.22 \%$ & $0.29 \%$ & $0.28 \%$ & $0.24 \%$ & $0.29 \%$ \\
\hline Croatia & $0.01 \%$ & $0.00 \%$ & $0.01 \%$ & $0.00 \%$ & $0.00 \%$ & $0.01 \%$ \\
\hline Cyprus & $0.20 \%$ & $0.15 \%$ & $0.20 \%$ & $0.19 \%$ & $0.17 \%$ & $0.19 \%$ \\
\hline Czech & $0.04 \%$ & $0.03 \%$ & $0.04 \%$ & $0.04 \%$ & $0.03 \%$ & $0.04 \%$ \\
\hline Denmark & $7.03 \%$ & $5.13 \%$ & $6.88 \%$ & $6.53 \%$ & $5.80 \%$ & $6.77 \%$ \\
\hline Estonia & $0.00 \%$ & $0.00 \%$ & $0.00 \%$ & $0.00 \%$ & $0.00 \%$ & $0.00 \%$ \\
\hline Finland & $7.87 \%$ & $5.75 \%$ & $7.70 \%$ & $7.31 \%$ & $6.49 \%$ & $7.58 \%$ \\
\hline France & $237.94 \%$ & $173.78 \%$ & $232.92 \%$ & $221.06 \%$ & $196.26 \%$ & $229.23 \%$ \\
\hline Georgia & $0.12 \%$ & $0.09 \%$ & $0.12 \%$ & $0.11 \%$ & $0.10 \%$ & $0.12 \%$ \\
\hline Germany & $12.87 \%$ & $9.40 \%$ & $12.60 \%$ & $11.96 \%$ & $10.62 \%$ & $12.40 \%$ \\
\hline Hungary & $0.01 \%$ & $0.01 \%$ & $0.01 \%$ & $0.01 \%$ & $0.01 \%$ & $0.01 \%$ \\
\hline India & $6.83 \%$ & $4.99 \%$ & $6.68 \%$ & $6.34 \%$ & $5.63 \%$ & $6.58 \%$ \\
\hline Indonesia & $0.00 \%$ & $0.00 \%$ & $0.00 \%$ & $0.00 \%$ & $0.00 \%$ & $0.00 \%$ \\
\hline Ireland & $1.50 \%$ & $1.09 \%$ & $1.47 \%$ & $1.39 \%$ & $1.23 \%$ & $1.44 \%$ \\
\hline Israel & $0.89 \%$ & $0.65 \%$ & $0.87 \%$ & $0.82 \%$ & $0.73 \%$ & $0.86 \%$ \\
\hline Italy & $30.72 \%$ & $22.44 \%$ & $30.07 \%$ & $28.54 \%$ & $25.34 \%$ & $29.59 \%$ \\
\hline Japan & $96.79 \%$ & $70.69 \%$ & $94.75 \%$ & $89.92 \%$ & $79.84 \%$ & $93.25 \%$ \\
\hline Luxembourg & $0.04 \%$ & $0.03 \%$ & $0.04 \%$ & $0.03 \%$ & $0.03 \%$ & $0.04 \%$ \\
\hline Malaysia & $4.53 \%$ & $3.31 \%$ & $4.43 \%$ & $4.21 \%$ & $3.74 \%$ & $4.36 \%$ \\
\hline Mexico & $28.41 \%$ & $20.75 \%$ & $27.81 \%$ & $26.39 \%$ & $23.43 \%$ & $27.37 \%$ \\
\hline Netherlands & $29.48 \%$ & $21.53 \%$ & $28.85 \%$ & $27.38 \%$ & $24.31 \%$ & $28.40 \%$ \\
\hline New Zealand & $0.01 \%$ & $0.01 \%$ & $0.01 \%$ & $0.01 \%$ & $0.01 \%$ & $0.01 \%$ \\
\hline Norway & $7.05 \%$ & $5.15 \%$ & $6.90 \%$ & $6.55 \%$ & $5.81 \%$ & $6.79 \%$ \\
\hline Portugal & $0.86 \%$ & $0.63 \%$ & $0.84 \%$ & $0.80 \%$ & $0.71 \%$ & $0.83 \%$ \\
\hline Russia & $55.47 \%$ & $40.51 \%$ & $54.30 \%$ & $51.54 \%$ & $45.75 \%$ & $53.44 \%$ \\
\hline Slovakia & $0.01 \%$ & $0.01 \%$ & $0.01 \%$ & $0.01 \%$ & $0.01 \%$ & $0.01 \%$ \\
\hline South Africa & $0.04 \%$ & $0.03 \%$ & $0.04 \%$ & $0.04 \%$ & $0.03 \%$ & $0.04 \%$ \\
\hline Spain & $82.99 \%$ & $60.61 \%$ & $81.24 \%$ & $77.10 \%$ & $68.45 \%$ & $79.95 \%$ \\
\hline Sweden & $8.34 \%$ & $6.09 \%$ & $8.16 \%$ & $7.75 \%$ & $6.88 \%$ & $8.03 \%$ \\
\hline Switzerland & $337.68 \%$ & $246.62 \%$ & $330.55 \%$ & $313.72 \%$ & $278.53 \%$ & $325.32 \%$ \\
\hline Turkey & $0.30 \%$ & $0.22 \%$ & $0.30 \%$ & $0.28 \%$ & $0.25 \%$ & $0.29 \%$ \\
\hline United Kingdom & $547.50 \%$ & $399.87 \%$ & $535.95 \%$ & $508.66 \%$ & $451.59 \%$ & $527.46 \%$ \\
\hline
\end{tabular}

returns (YTC_SCORE_75 and YTM_SCORE_75) exhibit the highest marginal preference responses to most factors across countries (see Table 6). Consistently with Table 4, we also find that the global marginal preference of sellers is stronger than that of the buyers, which indicates that bankruptcy protection and financial regulation compliance are the primary roles of CoCo bonds at a global level.

Overall, we find a stronger response of global sellers, which suggests that CoCo bonds are mainly considered as a bankruptcy protection device which also satisfies financial regulations. On the other hand, global buyers prefer to have CoCo bonds with high returns, low risk, perpetual maturity and small amounts issued by overvalued, large sized, financially sound banks. 


\section{Table 6}

Factor average CoCo bond's global buyer and seller's preference scores with incremental factor change. The following tables present the incremental change in CoCo bond's global buyer (Panel A and B) and seller's (Panel C and D) factor average preference scores based on the 25th (SCORE_25), 50th (SCORE_50) and 75th (SCORE_75) percentile benchmarks of YTC_SCORE (Panel A and C) and YTM_SCORE (Panel B and D). The tables below summarise the calculated factor average preference scores in Appendices B-E.

\begin{tabular}{|c|c|c|c|c|c|c|}
\hline \multicolumn{7}{|c|}{ Panel A. Global buyer's factor average preference scores } \\
\hline \multirow[b]{2}{*}{ Factors } & \multicolumn{3}{|l|}{$\Delta \mathrm{YTC}$} & \multicolumn{3}{|l|}{$\Delta \mathrm{YTM}$} \\
\hline & SCORE_25 & SCORE_50 & SCORE_75 & SCORE_25 & SCORE_50 & SCORE_75 \\
\hline $\mathrm{CPN}$ & $20.98 \%$ & $25.01 \%$ & $29.55 \%$ & $23.82 \%$ & $23.26 \%$ & $28.47 \%$ \\
\hline $\mathrm{CPN} \times \mathrm{CON}$ & $15.23 \%$ & & & & & \\
\hline $\mathrm{CPN} \times \mathrm{CRD}$ & $21.46 \%$ & $21.13 \%$ & $19.33 \%$ & $20.95 \%$ & $21.32 \%$ & $19.55 \%$ \\
\hline TRI & & $11.54 \%$ & $17.15 \%$ & & $13.33 \%$ & $18.25 \%$ \\
\hline $\mathrm{CON}$ & $11.84 \%$ & & $8.30 \%$ & & $13.19 \%$ & $8.81 \%$ \\
\hline CRD & & & $26.53 \%$ & & & \\
\hline MAT & & $87.97 \%$ & $0.00 \%$ & & $87.97 \%$ & \\
\hline AMT & & & $12.96 \%$ & & & $12.53 \%$ \\
\hline $\mathrm{AMT} \times \mathrm{ROE}$ & & & $22.32 \%$ & & & $22.34 \%$ \\
\hline CDS & & & $18.59 \%$ & & $19.40 \%$ & $18.05 \%$ \\
\hline $\mathrm{P} / \mathrm{B}$ & & & $25.26 \%$ & & & $26.91 \%$ \\
\hline SIZE & & & $24.08 \%$ & & & \\
\hline TRC/RWA & & & $24.70 \%$ & & & $24.76 \%$ \\
\hline CPI & & & $16.53 \%$ & & & \\
\hline \multicolumn{7}{|c|}{ Panel B. Global seller's factor average preference scores } \\
\hline \multirow[b]{2}{*}{ Factors } & \multicolumn{3}{|l|}{$\Delta \mathrm{YTC}$} & \multicolumn{3}{|l|}{$\Delta \mathrm{YTM}$} \\
\hline & SCORE_25 & SCORE_50 & SCORE_75 & SCORE_25 & SCORE_50 & SCORE_75 \\
\hline $\mathrm{CPN}$ & $66.99 \%$ & $62.96 \%$ & $58.43 \%$ & $64.15 \%$ & $64.71 \%$ & $59.50 \%$ \\
\hline $\mathrm{CPN} \times \mathrm{CON}$ & $72.74 \%$ & & & & & \\
\hline $\mathrm{CPN} \times \mathrm{CRD}$ & $66.52 \%$ & $66.84 \%$ & $68.64 \%$ & $67.02 \%$ & $66.65 \%$ & $68.42 \%$ \\
\hline TRI & & $76.43 \%$ & $70.83 \%$ & & $74.64 \%$ & $69.72 \%$ \\
\hline $\mathrm{CON}$ & $76.13 \%$ & & $79.67 \%$ & & $74.79 \%$ & $79.16 \%$ \\
\hline CRD & & & $61.45 \%$ & & & \\
\hline MAT & & $0.00 \%$ & $87.97 \%$ & & $0.00 \%$ & \\
\hline AMT & & & $75.01 \%$ & & & $75.45 \%$ \\
\hline $\mathrm{AMT} \times \mathrm{ROE}$ & & & $65.65 \%$ & & & $65.64 \%$ \\
\hline CDS & & & $69.38 \%$ & & $68.58 \%$ & $69.92 \%$ \\
\hline $\mathrm{P} / \mathrm{B}$ & & & $62.71 \%$ & & & $61.07 \%$ \\
\hline SIZE & & & $63.89 \%$ & & & \\
\hline TRC/RWA & & & $63.27 \%$ & & & $63.21 \%$ \\
\hline CPI & & & $71.45 \%$ & & & \\
\hline
\end{tabular}

\section{Conclusions}

To date only a limited number of studies have analysed the CoCo bond issuance effect on general equity investors. There has been a consensus that the reaction of CDS spreads to CoCo bond issuance is negative (Avdjiev et al., 2015; Vallée, 2016; Ammann et al., 2017) while the equity market shows insignificant (Avdjiev et al., 2015; Vallée, 2016), positive (Ammann et al., 2017) or negative (Liao et al., 2017) reactions. This paper focuses on the preferences of CoCo bond buyers and sellers considering both bond and issuing bank's characteristics from 1 April 2010 to 18 December 2019, unlike the few existing CoCo bond event studies that only analyse the behaviour of general equity holders. It also provides evidence on the role of country-specific CoCo bond market concentration. In our analysis we assume that buyers prefer CoCo bonds with a higher safety-adjusted return (measured by the bid yield-to-call or bid yield-to-maturity) multiplied by the spread of common equity tier 1 ratio on the CoCo bond's trigger level, and the opposite for sellers.

We find that buyers (as opposed to sellers) prefer CoCo bonds with a high return-to-risk, a low trigger and conversion probability (to avoid internalising the losses of the issuing banks) and a smaller amount issued (to prevent diluting the existing shareholders' ownerships). They also prefer CoCo bonds to be issued by large sized, financially sound banks with high profitability and low default risk. On the other hand, sellers are mainly interested in these fixed-income securities as a bankruptcy protection device and to satisfy financial regulations. Thus, they prefer to issue larger amounts of CoCo bonds when they are not financially sound, and also to provide lower coupon payments to CoCo bond investors.

We analyse preferences in more detail by running multinomial logistic regressions including both bond and issuing bank's characteristic to obtain the preference scores expressed in probabilities, and define buyers as having a preference for CoCo bonds if their safety-adjusted return is higher than the corresponding low (25th), medium (50th) and high (75th) annual percentile values; this variable takes value one, two and three if it is greater than these percentiles and zero otherwise; we also assume that the preferences of buyers and sellers are mutually exclusive. By running the multinomial logistic regressions, we also estimate the partial impact of a marginal change in each of the explanatory variables (e.g., cou- 
pon rate, trigger level, amount issued, etc.) on the probability of having CoCo bond's safety-adjusted returns in the low, medium and high percentiles.

We find that CoCo bond buyers in the low percentile are growth investors mainly responsive to the coupon payments they receive. Buyers in the medium percentile are instead value investors who mostly prefer long-term investments, i.e. CoCo bonds with perpetual maturity. Finally, the high percentile buyers are relatively active investors who monitor most CoCo bonds' and issuing bank's characteristics along with the underlying economic situation. However, sellers are more responsive than buyers to the features of CoCo bonds and issuing banks. This implies that the sellers' needs to have a bankruptcy protection device and comply with the Basel III financial regulations play a more important role than the buyers' motivation to increase their financial income from this fixed-income security. Therefore, CoCo bonds sellers and buyers exhibit risk-loving and risk-averse behaviour respectively; sellers prefer to issue them when they face increasing financial risk while the buyers prefer to purchase them when sellers are financially stable.

We also consider the country-specific CoCo bond market concentration (by calculating Herfindahl indices for each country using the CoCo bond issue size for each bank) assuming that higher market competition gives more trading power to both buyers and sellers. We find that global buyers and sellers of CoCo bonds in the main European countries (e.g., France, Germany, Italy, Netherlands, Russia, Spain, Switzerland and UK), Brazil, Mexico and a few of the main Far East countries (China and Japan) are very responsive to CoCo bond and issuing bank's characteristics, with the UK and China exhibiting the strongest responses. Further, both buyers and sellers in the highest (75th) percentile show strongest preference response to largest number of CoCo bond and issuing bank's factors. These findings are relevant to both regulators, investors and banks interested in understanding the conflicting preferences of CoCo bond buyers and sellers, their determinants, and their geographical features.

\section{Acknowledgements}

We are grateful to two anonymous referees for their useful comments. 


\section{Appendix A. Correlation matrix}

The following table presents the Pearson's correlation matrix for the regressors in our sample. ${ }^{*}$ stands for significance at the $10 \%$ level, ${ }^{* *}$ at the $5 \%$ level and ${ }^{* * *}$ represents at the $1 \%$ level.

\begin{tabular}{|c|c|c|c|c|c|c|c|c|c|c|c|c|c|c|}
\hline & $\mathrm{CPN}$ & MAT & AMT & TRI & CRD & $\mathrm{CON}$ & ROE & SIZE & $\mathrm{P} / \mathrm{B}$ & TRC/RWA & RGDP & CPI & CDS & CET1_Ratio \\
\hline CPN & $1^{* * *}$ & & & & & & & & & & & & & \\
\hline MAT & -0.05 & $1^{* * *}$ & & & & & & & & & & & & \\
\hline AMT & 0.01 & $-0.09^{* *}$ & $1^{* * *}$ & & & & & & & & & & & \\
\hline TRI & -0.02 & $0.41^{* * *}$ & $0.07^{*}$ & $1^{* * *}$ & & & & & & & & & & \\
\hline CRD & $-0.18^{* * *}$ & -0.03 & $-0.38^{* * *}$ & $-0.11^{*}$ & $1^{* * *}$ & & & & & & & & & \\
\hline CON & $0.1^{* * *}$ & $0.1^{* * *}$ & $0.39^{* * *}$ & $0.25^{* * *}$ & $-0.07^{*}$ & $1^{* * *}$ & & & & & & & & \\
\hline ROE & -0.03 & -0.05 & 0 & $-0.21^{* * *}$ & $0.16^{* * *}$ & $-0.06^{*}$ & $1^{* * *}$ & & & & & & & \\
\hline SIZE & -0.06 & $-0.1^{* * *}$ & $0.4^{* * *}$ & $-0.12^{* * *}$ & -0.04 & 0.06 & $0.66^{* * *}$ & $1^{* * *}$ & & & & & & \\
\hline $\mathrm{P} / \mathrm{B}$ & 0 & -0.01 & $-0.22^{* * *}$ & $-0.16^{* * *}$ & $0.2^{* * *}$ & $-0.15^{* * *}$ & $0.72^{* * *}$ & $0.45^{* * *}$ & $1^{* * *}$ & & & & & \\
\hline TRC/RWA & 0.02 & -0.04 & -0.03 & $-0.09^{* *}$ & 0.04 & $-0.1^{* * *}$ & $0.73^{* * *}$ & $0.62^{* * *}$ & $0.72^{* * *}$ & $1^{* * *}$ & & & & \\
\hline RGDP & $-0.1^{* * *}$ & 0.03 & $0.08^{* *}$ & $-0.07^{*}$ & $0.19^{* * *}$ & $0.12^{* * *}$ & $0.57^{* * *}$ & $0.52^{* * *}$ & $0.4^{* * *}$ & $0.41^{* * *}$ & $1^{* * *}$ & & & \\
\hline CPI & $0.12^{* * *}$ & $-0.14^{* * *}$ & -0.06 & $-0.23^{* * *}$ & $0.1^{* * *}$ & $-0.09^{* *}$ & $0.56^{* * *}$ & $0.49^{* * *}$ & $0.48^{* * *}$ & $0.51^{* * *}$ & $0.62^{* * *}$ & $1^{* * *}$ & & \\
\hline CDS & 0.04 & $-0.14^{* * *}$ & 0 & $-0.21^{* * *}$ & $0.13^{* * *}$ & -0.04 & $0.54^{* * *}$ & $0.51^{* * *}$ & $0.56^{* * *}$ & $0.5^{* * *}$ & $0.48^{* * *}$ & $0.64^{* * *}$ & $1^{* * *}$ & \\
\hline CET1_Spread & $0.11^{* * *}$ & $-0.2^{* * *}$ & $-0.2^{* * *}$ & $-0.34^{* * *}$ & $0.13^{* * *}$ & $-0.13^{* * *}$ & $0.42^{* * *}$ & $0.24^{* * *}$ & $0.47^{* * *}$ & $0.49^{* * *}$ & 0.04 & $0.15^{* * *}$ & $0.23^{* * *}$ & $1^{* * *}$ \\
\hline
\end{tabular}




\section{Appendix B. Global CoCo bond buyers' YTC_SCORE preference scores with incremental factor change}

The following tables present the incremental change in CoCo bond's global preference scores based on the 25th, 50th and 75th percentile benchmarks of YTC_SCORE in Panel A ( $\triangle$ YTC_SCORE_25), B ( $\Delta$ YTC_SCORE_50) and C ( $\Delta$ YTC_SCORE_75), respectively. We provide the global preference scores with the incremental changes in significant factors in Tables 3 and 4. The preference scores are scaled by the market power score for each country to provide country specific preference scores as in our Eqs. (8) and (9). We report the country and factor average preference responses which are the average values across each row and column, respectively.

\begin{tabular}{|c|c|c|c|}
\hline \multicolumn{4}{|c|}{ Panel A. Buyers' $\Delta$ YTC_SCORE_25 } \\
\hline & CPN & $\mathrm{CPN} \times \mathrm{CRD}$ & $\begin{array}{l}\text { Country } \\
\text { Average }\end{array}$ \\
\hline Australia & $1.23 \%$ & $1.09 \%$ & $1.16 \%$ \\
\hline Austria & $1.12 \%$ & $0.99 \%$ & $1.06 \%$ \\
\hline Belgium & $0.87 \%$ & $0.76 \%$ & $0.81 \%$ \\
\hline Brazil & $15.38 \%$ & $13.53 \%$ & $14.46 \%$ \\
\hline China & $354.69 \%$ & $311.91 \%$ & $333.30 \%$ \\
\hline Colombia & $0.10 \%$ & $0.09 \%$ & $0.09 \%$ \\
\hline Croatia & $0.00 \%$ & $0.00 \%$ & $0.00 \%$ \\
\hline Cyprus & $0.07 \%$ & $0.06 \%$ & $0.06 \%$ \\
\hline Czech & $0.01 \%$ & $0.01 \%$ & $0.01 \%$ \\
\hline Denmark & $2.37 \%$ & $2.09 \%$ & $2.23 \%$ \\
\hline Estonia & $0.00 \%$ & $0.00 \%$ & $0.00 \%$ \\
\hline Finland & $2.66 \%$ & $2.34 \%$ & $2.50 \%$ \\
\hline France & $80.30 \%$ & $70.61 \%$ & $75.45 \%$ \\
\hline Georgia & $0.04 \%$ & $0.04 \%$ & $0.04 \%$ \\
\hline Germany & $4.34 \%$ & $3.82 \%$ & $4.08 \%$ \\
\hline Hungary & $0.00 \%$ & $0.00 \%$ & $0.00 \%$ \\
\hline India & $2.30 \%$ & $2.03 \%$ & $2.17 \%$ \\
\hline Indonesia & $0.00 \%$ & $0.00 \%$ & $0.00 \%$ \\
\hline Ireland & $0.51 \%$ & $0.44 \%$ & $0.47 \%$ \\
\hline Israel & $0.30 \%$ & $0.26 \%$ & $0.28 \%$ \\
\hline Italy & $10.37 \%$ & $9.12 \%$ & $9.74 \%$ \\
\hline Japan & $32.66 \%$ & $28.72 \%$ & $30.69 \%$ \\
\hline Luxembourg & $0.01 \%$ & $0.01 \%$ & $0.01 \%$ \\
\hline Malaysia & $1.53 \%$ & $1.34 \%$ & $1.44 \%$ \\
\hline Mexico & $9.59 \%$ & $8.43 \%$ & $9.01 \%$ \\
\hline Netherlands & $9.95 \%$ & $8.75 \%$ & $9.35 \%$ \\
\hline New Zealand & $0.00 \%$ & $0.00 \%$ & $0.00 \%$ \\
\hline Norway & $2.38 \%$ & $2.09 \%$ & $2.24 \%$ \\
\hline Portugal & $0.29 \%$ & $0.26 \%$ & $0.27 \%$ \\
\hline Russia & $18.72 \%$ & $16.46 \%$ & $17.59 \%$ \\
\hline Slovakia & $0.00 \%$ & $0.00 \%$ & $0.00 \%$ \\
\hline South Africa & $0.01 \%$ & $0.01 \%$ & $0.01 \%$ \\
\hline Spain & $28.01 \%$ & $24.63 \%$ & $26.32 \%$ \\
\hline Sweden & $2.81 \%$ & $2.47 \%$ & $2.64 \%$ \\
\hline Switzerland & $113.95 \%$ & $100.21 \%$ & $107.08 \%$ \\
\hline Turkey & $0.10 \%$ & $0.09 \%$ & $0.10 \%$ \\
\hline United Kingdom & $184.76 \%$ & $162.48 \%$ & $173.62 \%$ \\
\hline Factor Average & $23.82 \%$ & $20.95 \%$ & \\
\hline
\end{tabular}




\begin{tabular}{|c|c|c|c|c|c|c|c|}
\hline \multicolumn{8}{|c|}{ Panel B. Buyers' $\Delta$ YTC_SCORE_50 } \\
\hline & CPN & $\mathrm{CPN} \times \mathrm{CRD}$ & TRI & CON & MAT & CDS & $\begin{array}{l}\text { Country } \\
\text { Average }\end{array}$ \\
\hline Australia & $1.21 \%$ & $1.11 \%$ & $0.69 \%$ & $0.68 \%$ & $4.56 \%$ & $1.01 \%$ & $1.54 \%$ \\
\hline Austria & $1.10 \%$ & $1.01 \%$ & $0.63 \%$ & $0.62 \%$ & $4.15 \%$ & $0.92 \%$ & $1.40 \%$ \\
\hline Belgium & $0.85 \%$ & $0.78 \%$ & $0.48 \%$ & $0.48 \%$ & $3.20 \%$ & $0.71 \%$ & $1.08 \%$ \\
\hline Brazil & $15.02 \%$ & $13.77 \%$ & $8.61 \%$ & $8.51 \%$ & $56.80 \%$ & $12.52 \%$ & $19.21 \%$ \\
\hline China & $346.37 \%$ & $317.43 \%$ & $198.46 \%$ & $196.31 \%$ & $1309.75 \%$ & $288.79 \%$ & $442.85 \%$ \\
\hline Colombia & $0.10 \%$ & $0.09 \%$ & $0.06 \%$ & $0.06 \%$ & $0.37 \%$ & $0.08 \%$ & $0.12 \%$ \\
\hline Croatia & $0.00 \%$ & $0.00 \%$ & $0.00 \%$ & $0.00 \%$ & $0.01 \%$ & $0.00 \%$ & $0.00 \%$ \\
\hline Cyprus & $0.07 \%$ & $0.06 \%$ & $0.04 \%$ & $0.04 \%$ & $0.25 \%$ & $0.06 \%$ & $0.09 \%$ \\
\hline Czech & $0.01 \%$ & $0.01 \%$ & $0.01 \%$ & $0.01 \%$ & $0.05 \%$ & $0.01 \%$ & $0.02 \%$ \\
\hline Denmark & $2.32 \%$ & $2.12 \%$ & $1.33 \%$ & $1.31 \%$ & $8.76 \%$ & $1.93 \%$ & $2.96 \%$ \\
\hline Estonia & $0.00 \%$ & $0.00 \%$ & $0.00 \%$ & $0.00 \%$ & $0.00 \%$ & $0.00 \%$ & $0.00 \%$ \\
\hline Finland & $2.59 \%$ & $2.38 \%$ & $1.49 \%$ & $1.47 \%$ & $9.80 \%$ & $2.16 \%$ & $3.32 \%$ \\
\hline France & $78.41 \%$ & $71.86 \%$ & $44.93 \%$ & $44.44 \%$ & $296.51 \%$ & $65.38 \%$ & $100.26 \%$ \\
\hline Georgia & $0.04 \%$ & $0.04 \%$ & $0.02 \%$ & $0.02 \%$ & $0.15 \%$ & $0.03 \%$ & $0.05 \%$ \\
\hline Germany & $4.24 \%$ & $3.89 \%$ & $2.43 \%$ & $2.40 \%$ & $16.04 \%$ & $3.54 \%$ & $5.42 \%$ \\
\hline Hungary & $0.00 \%$ & $0.00 \%$ & $0.00 \%$ & $0.00 \%$ & $0.02 \%$ & $0.00 \%$ & $0.01 \%$ \\
\hline India & $2.25 \%$ & $2.06 \%$ & $1.29 \%$ & $1.28 \%$ & $8.51 \%$ & $1.88 \%$ & $2.88 \%$ \\
\hline Indonesia & $0.00 \%$ & $0.00 \%$ & $0.00 \%$ & $0.00 \%$ & $0.00 \%$ & $0.00 \%$ & $0.00 \%$ \\
\hline Ireland & $0.49 \%$ & $0.45 \%$ & $0.28 \%$ & $0.28 \%$ & $1.87 \%$ & $0.41 \%$ & $0.63 \%$ \\
\hline Israel & $0.29 \%$ & $0.27 \%$ & $0.17 \%$ & $0.17 \%$ & $1.11 \%$ & $0.24 \%$ & $0.37 \%$ \\
\hline Italy & $10.12 \%$ & $9.28 \%$ & $5.80 \%$ & $5.74 \%$ & $38.28 \%$ & $8.44 \%$ & $12.94 \%$ \\
\hline Japan & $31.90 \%$ & $29.23 \%$ & $18.28 \%$ & $18.08 \%$ & $120.62 \%$ & $26.60 \%$ & $40.78 \%$ \\
\hline Luxembourg & $0.01 \%$ & $0.01 \%$ & $0.01 \%$ & $0.01 \%$ & $0.05 \%$ & $0.01 \%$ & $0.02 \%$ \\
\hline Malaysia & $1.49 \%$ & $1.37 \%$ & $0.86 \%$ & $0.85 \%$ & $5.65 \%$ & $1.24 \%$ & $1.91 \%$ \\
\hline Mexico & $9.36 \%$ & $8.58 \%$ & $5.36 \%$ & $5.31 \%$ & $35.40 \%$ & $7.81 \%$ & $11.97 \%$ \\
\hline Netherlands & $9.71 \%$ & $8.90 \%$ & $5.57 \%$ & $5.51 \%$ & $36.73 \%$ & $8.10 \%$ & $12.42 \%$ \\
\hline New Zealand & $0.00 \%$ & $0.00 \%$ & $0.00 \%$ & $0.00 \%$ & $0.02 \%$ & $0.00 \%$ & $0.01 \%$ \\
\hline Norway & $2.32 \%$ & $2.13 \%$ & $1.33 \%$ & $1.32 \%$ & $8.78 \%$ & $1.94 \%$ & $2.97 \%$ \\
\hline Portugal & $0.28 \%$ & $0.26 \%$ & $0.16 \%$ & $0.16 \%$ & $1.07 \%$ & $0.24 \%$ & $0.36 \%$ \\
\hline Russia & $18.28 \%$ & $16.75 \%$ & $10.47 \%$ & $10.36 \%$ & $69.12 \%$ & $15.24 \%$ & $23.37 \%$ \\
\hline Slovakia & $0.00 \%$ & $0.00 \%$ & $0.00 \%$ & $0.00 \%$ & $0.02 \%$ & $0.00 \%$ & $0.01 \%$ \\
\hline South Africa & $0.01 \%$ & $0.01 \%$ & $0.01 \%$ & $0.01 \%$ & $0.05 \%$ & $0.01 \%$ & $0.02 \%$ \\
\hline Spain & $27.35 \%$ & $25.06 \%$ & $15.67 \%$ & $15.50 \%$ & $103.42 \%$ & $22.80 \%$ & $34.97 \%$ \\
\hline Sweden & $2.75 \%$ & $2.52 \%$ & $1.57 \%$ & $1.56 \%$ & $10.39 \%$ & $2.29 \%$ & $3.51 \%$ \\
\hline Switzerland & $111.28 \%$ & $101.98 \%$ & $63.76 \%$ & $63.07 \%$ & $420.80 \%$ & $92.78 \%$ & $142.28 \%$ \\
\hline Turkey & $0.10 \%$ & $0.09 \%$ & $0.06 \%$ & $0.06 \%$ & $0.38 \%$ & $0.08 \%$ & $0.13 \%$ \\
\hline $\begin{array}{l}\text { United } \\
\text { Kingdom }\end{array}$ & $180.43 \%$ & $165.35 \%$ & $103.38 \%$ & $102.26 \%$ & $682.27 \%$ & $150.44 \%$ & $230.69 \%$ \\
\hline Factor Average & $23.26 \%$ & $21.32 \%$ & $13.33 \%$ & $13.19 \%$ & $87.97 \%$ & $19.40 \%$ & \\
\hline
\end{tabular}

\begin{tabular}{|c|c|c|c|c|c|c|c|c|c|c|}
\hline \multicolumn{11}{|c|}{ Panel C. Buyers' $\triangle$ YTC_SCORE_75 } \\
\hline & CPN & $\begin{array}{l}\mathrm{CPN} \times \\
\mathrm{CRD}\end{array}$ & TRI & $\mathrm{CON}$ & AMT & $\begin{array}{l}\text { AMT } \times \\
\text { ROE }\end{array}$ & CDS & $\mathrm{P} / \mathrm{B}$ & $\begin{array}{l}\text { TRC/ } \\
\text { RWA }\end{array}$ & $\begin{array}{l}\text { Country } \\
\text { Average }\end{array}$ \\
\hline Australia & $1.48 \%$ & $1.01 \%$ & $0.95 \%$ & $0.46 \%$ & $0.65 \%$ & $1.16 \%$ & $0.94 \%$ & $1.39 \%$ & $1.28 \%$ & $1.03 \%$ \\
\hline Austria & $1.34 \%$ & $0.92 \%$ & $0.86 \%$ & $0.42 \%$ & $0.59 \%$ & $1.05 \%$ & $0.85 \%$ & $1.27 \%$ & $1.17 \%$ & $0.94 \%$ \\
\hline Belgium & $1.04 \%$ & $0.71 \%$ & $0.66 \%$ & $0.32 \%$ & $0.46 \%$ & $0.81 \%$ & $0.66 \%$ & $0.98 \%$ & $0.90 \%$ & $0.73 \%$ \\
\hline Brazil & $18.38 \%$ & $12.62 \%$ & $11.79 \%$ & $5.69 \%$ & $8.09 \%$ & $14.42 \%$ & $11.65 \%$ & $17.37 \%$ & $15.99 \%$ & $12.89 \%$ \\
\hline China & $423.87 \%$ & $291.04 \%$ & $271.78 \%$ & $131.19 \%$ & $186.50 \%$ & $332.54 \%$ & $268.71 \%$ & $400.58 \%$ & $368.69 \%$ & $297.21 \%$ \\
\hline Colombia & $0.12 \%$ & $0.08 \%$ & $0.08 \%$ & $0.04 \%$ & $0.05 \%$ & $0.09 \%$ & $0.08 \%$ & $0.11 \%$ & $0.10 \%$ & $0.08 \%$ \\
\hline Croatia & $0.00 \%$ & $0.00 \%$ & $0.00 \%$ & $0.00 \%$ & $0.00 \%$ & $0.00 \%$ & $0.00 \%$ & $0.00 \%$ & $0.00 \%$ & $0.00 \%$ \\
\hline Cyprus & $0.08 \%$ & $0.06 \%$ & $0.05 \%$ & $0.03 \%$ & $0.04 \%$ & $0.06 \%$ & $0.05 \%$ & $0.08 \%$ & $0.07 \%$ & $0.06 \%$ \\
\hline
\end{tabular}


Global CoCo bond buyers' YTC_SCORE preference scores with incremental factor change (continued)

\begin{tabular}{|c|c|c|c|c|c|c|c|c|c|c|}
\hline \multicolumn{11}{|c|}{ Panel C. Buyers' $\triangle$ YTC_SCORE_75 } \\
\hline & CPN & $\begin{array}{l}\mathrm{CPN} \times \\
\mathrm{CRD}\end{array}$ & TRI & CON & AMT & $\begin{array}{l}\text { AMT } \times \\
\text { ROE }\end{array}$ & CDS & $\mathrm{P} / \mathrm{B}$ & $\begin{array}{l}\text { TRC/ } \\
\text { RWA }\end{array}$ & $\begin{array}{l}\text { Country } \\
\text { Average }\end{array}$ \\
\hline Czech & $0.02 \%$ & $0.01 \%$ & $0.01 \%$ & $0.00 \%$ & $0.01 \%$ & $0.01 \%$ & $0.01 \%$ & $0.02 \%$ & $0.01 \%$ & $0.01 \%$ \\
\hline Denmark & $2.83 \%$ & $1.95 \%$ & $1.82 \%$ & $0.88 \%$ & $1.25 \%$ & $2.22 \%$ & $1.80 \%$ & $2.68 \%$ & $2.47 \%$ & $1.99 \%$ \\
\hline Estonia & $0.00 \%$ & $0.00 \%$ & $0.00 \%$ & $0.00 \%$ & $0.00 \%$ & $0.00 \%$ & $0.00 \%$ & $0.00 \%$ & $0.00 \%$ & $0.00 \%$ \\
\hline Finland & $3.17 \%$ & $2.18 \%$ & $2.03 \%$ & $0.98 \%$ & $1.40 \%$ & $2.49 \%$ & $2.01 \%$ & $3.00 \%$ & $2.76 \%$ & $2.22 \%$ \\
\hline France & $95.96 \%$ & $65.89 \%$ & $61.53 \%$ & $29.70 \%$ & $42.22 \%$ & $75.28 \%$ & $60.83 \%$ & $90.69 \%$ & $83.47 \%$ & $67.29 \%$ \\
\hline Georgia & $0.05 \%$ & $0.03 \%$ & $0.03 \%$ & $0.02 \%$ & $0.02 \%$ & $0.04 \%$ & $0.03 \%$ & $0.05 \%$ & $0.04 \%$ & $0.03 \%$ \\
\hline Germany & $5.19 \%$ & $3.56 \%$ & $3.33 \%$ & $1.61 \%$ & $2.28 \%$ & $4.07 \%$ & $3.29 \%$ & $4.91 \%$ & $4.52 \%$ & $3.64 \%$ \\
\hline Hungary & $0.01 \%$ & $0.00 \%$ & $0.00 \%$ & $0.00 \%$ & $0.00 \%$ & $0.00 \%$ & $0.00 \%$ & $0.01 \%$ & $0.00 \%$ & $0.00 \%$ \\
\hline India & $2.75 \%$ & $1.89 \%$ & $1.77 \%$ & $0.85 \%$ & $1.21 \%$ & $2.16 \%$ & $1.75 \%$ & $2.60 \%$ & $2.40 \%$ & $1.93 \%$ \\
\hline Indonesia & $0.00 \%$ & $0.00 \%$ & $0.00 \%$ & $0.00 \%$ & $0.00 \%$ & $0.00 \%$ & $0.00 \%$ & $0.00 \%$ & $0.00 \%$ & $0.00 \%$ \\
\hline Ireland & $0.60 \%$ & $0.41 \%$ & $0.39 \%$ & $0.19 \%$ & $0.27 \%$ & $0.47 \%$ & $0.38 \%$ & $0.57 \%$ & $0.53 \%$ & $0.42 \%$ \\
\hline Israel & $0.36 \%$ & $0.25 \%$ & $0.23 \%$ & $0.11 \%$ & $0.16 \%$ & $0.28 \%$ & $0.23 \%$ & $0.34 \%$ & $0.31 \%$ & $0.25 \%$ \\
\hline Italy & $12.39 \%$ & $8.51 \%$ & $7.94 \%$ & $3.83 \%$ & $5.45 \%$ & $9.72 \%$ & $7.85 \%$ & $11.71 \%$ & $10.78 \%$ & $8.69 \%$ \\
\hline Japan & $39.03 \%$ & $26.80 \%$ & $25.03 \%$ & $12.08 \%$ & $17.18 \%$ & $30.62 \%$ & $24.75 \%$ & $36.89 \%$ & $33.95 \%$ & $27.37 \%$ \\
\hline Luxembourg & $0.02 \%$ & $0.01 \%$ & $0.01 \%$ & $0.00 \%$ & $0.01 \%$ & $0.01 \%$ & $0.01 \%$ & $0.01 \%$ & $0.01 \%$ & $0.01 \%$ \\
\hline Malaysia & $1.83 \%$ & $1.25 \%$ & $1.17 \%$ & $0.57 \%$ & $0.80 \%$ & $1.43 \%$ & $1.16 \%$ & $1.73 \%$ & $1.59 \%$ & $1.28 \%$ \\
\hline Mexico & $11.46 \%$ & $7.87 \%$ & $7.35 \%$ & $3.55 \%$ & $5.04 \%$ & $8.99 \%$ & $7.26 \%$ & $10.83 \%$ & $9.97 \%$ & $8.03 \%$ \\
\hline Netherlands & $11.89 \%$ & $8.16 \%$ & $7.62 \%$ & $3.68 \%$ & $5.23 \%$ & $9.33 \%$ & $7.54 \%$ & $11.23 \%$ & $10.34 \%$ & $8.34 \%$ \\
\hline $\begin{array}{l}\text { New } \\
\text { Zealand }\end{array}$ & $0.01 \%$ & $0.00 \%$ & $0.00 \%$ & $0.00 \%$ & $0.00 \%$ & $0.00 \%$ & $0.00 \%$ & $0.00 \%$ & $0.00 \%$ & $0.00 \%$ \\
\hline Norway & $2.84 \%$ & $1.95 \%$ & $1.82 \%$ & $0.88 \%$ & $1.25 \%$ & $2.23 \%$ & $1.80 \%$ & $2.69 \%$ & $2.47 \%$ & $1.99 \%$ \\
\hline Portugal & $0.35 \%$ & $0.24 \%$ & $0.22 \%$ & $0.11 \%$ & $0.15 \%$ & $0.27 \%$ & $0.22 \%$ & $0.33 \%$ & $0.30 \%$ & $0.24 \%$ \\
\hline Russia & $22.37 \%$ & $15.36 \%$ & $14.34 \%$ & $6.92 \%$ & $9.84 \%$ & $17.55 \%$ & $14.18 \%$ & $21.14 \%$ & $19.46 \%$ & $15.69 \%$ \\
\hline Slovakia & $0.01 \%$ & $0.00 \%$ & $0.00 \%$ & $0.00 \%$ & $0.00 \%$ & $0.00 \%$ & $0.00 \%$ & $0.01 \%$ & $0.00 \%$ & $0.00 \%$ \\
\hline South Africa & $0.02 \%$ & $0.01 \%$ & $0.01 \%$ & $0.00 \%$ & $0.01 \%$ & $0.01 \%$ & $0.01 \%$ & $0.01 \%$ & $0.01 \%$ & $0.01 \%$ \\
\hline Spain & $33.47 \%$ & $22.98 \%$ & $21.46 \%$ & $10.36 \%$ & $14.73 \%$ & $26.26 \%$ & $21.22 \%$ & $31.63 \%$ & $29.11 \%$ & $23.47 \%$ \\
\hline Sweden & $3.36 \%$ & $2.31 \%$ & $2.16 \%$ & $1.04 \%$ & $1.48 \%$ & $2.64 \%$ & $2.13 \%$ & $3.18 \%$ & $2.93 \%$ & $2.36 \%$ \\
\hline Switzerland & $136.18 \%$ & $93.51 \%$ & $87.32 \%$ & $42.15 \%$ & $59.92 \%$ & $106.84 \%$ & $86.33 \%$ & $128.70 \%$ & $118.45 \%$ & $95.49 \%$ \\
\hline Turkey & $0.12 \%$ & $0.08 \%$ & $0.08 \%$ & $0.04 \%$ & $0.05 \%$ & $0.10 \%$ & $0.08 \%$ & $0.12 \%$ & $0.11 \%$ & $0.09 \%$ \\
\hline $\begin{array}{l}\text { United } \\
\text { Kingdom }\end{array}$ & $220.80 \%$ & $151.61 \%$ & $141.58 \%$ & $68.34 \%$ & $97.15 \%$ & $173.22 \%$ & $139.98 \%$ & $208.67 \%$ & $192.06 \%$ & $154.82 \%$ \\
\hline $\begin{array}{l}\text { Factor } \\
\text { Average }\end{array}$ & $28.47 \%$ & $19.55 \%$ & $18.25 \%$ & $8.81 \%$ & $12.53 \%$ & $22.34 \%$ & $18.05 \%$ & $26.91 \%$ & $24.76 \%$ & \\
\hline
\end{tabular}

\section{Appendix C. Global CoCo bond buyers' YTM_SCORE preference scores with incremental factor change}

The following tables present the incremental change in CoCo bond's global preference scores based on the 25th, 50th and

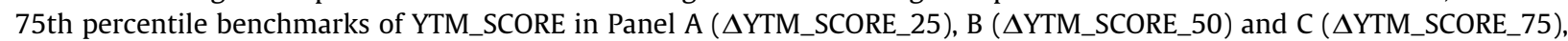
respectively. We provide the global preference scores with the incremental changes in significant factors in Table 3 and 4 . The preference scores are scaled by the market power score for each country to provide country specific preference scores as in our equation (8) and (9). We report the country and factor average preference responses which are the average values across each row and column, respectively.

\begin{tabular}{llllll}
\hline \multicolumn{2}{l}{ Panel A. Buyers' $\Delta$ YTM_SCORE_25 } & & & \\
\hline & CPN & CPN $\times$ CON & CPN $\times$ CRD & CON & Country Average \\
\hline Australia & $1.09 \%$ & $0.79 \%$ & $1.11 \%$ & $0.61 \%$ & $0.90 \%$ \\
Austria & $0.99 \%$ & $0.72 \%$ & $1.01 \%$ & $0.56 \%$ & $0.82 \%$ \\
Belgium & $0.76 \%$ & $0.55 \%$ & $0.78 \%$ & $0.43 \%$ & $0.63 \%$ \\
Brazil & $13.55 \%$ & $9.84 \%$ & $13.85 \%$ & $7.65 \%$ & $11.22 \%$ \\
China & $312.41 \%$ & $226.77 \%$ & $319.45 \%$ & $176.31 \%$ & $258.74 \%$
\end{tabular}

(continued on next page) 
Global CoCo bond buyers' YTM_SCORE preference scores with incremental factor change (continued)

\begin{tabular}{|c|c|c|c|c|c|}
\hline \multicolumn{6}{|c|}{ Panel A. Buyers' $\Delta$ YTM_SCORE_25 } \\
\hline & CPN & $\mathrm{CPN} \times \mathrm{CON}$ & $\mathrm{CPN} \times \mathrm{CRD}$ & $\mathrm{CON}$ & Country Average \\
\hline Colombia & $0.09 \%$ & $0.06 \%$ & $0.09 \%$ & $0.05 \%$ & $0.07 \%$ \\
\hline Croatia & $0.00 \%$ & $0.00 \%$ & $0.00 \%$ & $0.00 \%$ & $0.00 \%$ \\
\hline Cyprus & $0.06 \%$ & $0.04 \%$ & $0.06 \%$ & $0.03 \%$ & $0.05 \%$ \\
\hline Czech & $0.01 \%$ & $0.01 \%$ & $0.01 \%$ & $0.01 \%$ & $0.01 \%$ \\
\hline Denmark & $2.09 \%$ & $1.52 \%$ & $2.14 \%$ & $1.18 \%$ & $1.73 \%$ \\
\hline Estonia & $0.00 \%$ & $0.00 \%$ & $0.00 \%$ & $0.00 \%$ & $0.00 \%$ \\
\hline Finland & $2.34 \%$ & $1.70 \%$ & $2.39 \%$ & $1.32 \%$ & $1.94 \%$ \\
\hline France & $70.73 \%$ & $51.34 \%$ & $72.32 \%$ & $39.92 \%$ & $58.57 \%$ \\
\hline Georgia & $0.04 \%$ & $0.03 \%$ & $0.04 \%$ & $0.02 \%$ & $0.03 \%$ \\
\hline Germany & $3.83 \%$ & $2.78 \%$ & $3.91 \%$ & $2.16 \%$ & $3.17 \%$ \\
\hline Hungary & $0.00 \%$ & $0.00 \%$ & $0.00 \%$ & $0.00 \%$ & $0.00 \%$ \\
\hline India & $2.03 \%$ & $1.47 \%$ & $2.08 \%$ & $1.15 \%$ & $1.68 \%$ \\
\hline Indonesia & $0.00 \%$ & $0.00 \%$ & $0.00 \%$ & $0.00 \%$ & $0.00 \%$ \\
\hline Ireland & $0.44 \%$ & $0.32 \%$ & $0.45 \%$ & $0.25 \%$ & $0.37 \%$ \\
\hline Israel & $0.26 \%$ & $0.19 \%$ & $0.27 \%$ & $0.15 \%$ & $0.22 \%$ \\
\hline Italy & $9.13 \%$ & $6.63 \%$ & $9.34 \%$ & $5.15 \%$ & $7.56 \%$ \\
\hline Japan & $28.77 \%$ & $20.88 \%$ & $29.42 \%$ & $16.24 \%$ & $23.83 \%$ \\
\hline Luxembourg & $0.01 \%$ & $0.01 \%$ & $0.01 \%$ & $0.01 \%$ & $0.01 \%$ \\
\hline Malaysia & $1.35 \%$ & $0.98 \%$ & $1.38 \%$ & $0.76 \%$ & $1.12 \%$ \\
\hline Mexico & $8.44 \%$ & $6.13 \%$ & $8.63 \%$ & $4.77 \%$ & $6.99 \%$ \\
\hline Netherlands & $8.76 \%$ & $6.36 \%$ & $8.96 \%$ & $4.94 \%$ & $7.26 \%$ \\
\hline New Zealand & $0.00 \%$ & $0.00 \%$ & $0.00 \%$ & $0.00 \%$ & $0.00 \%$ \\
\hline Norway & $2.09 \%$ & $1.52 \%$ & $2.14 \%$ & $1.18 \%$ & $1.74 \%$ \\
\hline Portugal & $0.26 \%$ & $0.19 \%$ & $0.26 \%$ & $0.14 \%$ & $0.21 \%$ \\
\hline Russia & $16.49 \%$ & $11.97 \%$ & $16.86 \%$ & $9.31 \%$ & $13.66 \%$ \\
\hline Slovakia & $0.00 \%$ & $0.00 \%$ & $0.00 \%$ & $0.00 \%$ & $0.00 \%$ \\
\hline South Africa & $0.01 \%$ & $0.01 \%$ & $0.01 \%$ & $0.01 \%$ & $0.01 \%$ \\
\hline Spain & $24.67 \%$ & $17.91 \%$ & $25.22 \%$ & $13.92 \%$ & $20.43 \%$ \\
\hline Sweden & $2.48 \%$ & $1.80 \%$ & $2.53 \%$ & $1.40 \%$ & $2.05 \%$ \\
\hline Switzerland & $100.37 \%$ & $72.86 \%$ & $102.63 \%$ & $56.65 \%$ & $83.13 \%$ \\
\hline Turkey & $0.09 \%$ & $0.07 \%$ & $0.09 \%$ & $0.05 \%$ & $0.07 \%$ \\
\hline United Kingdom & $162.74 \%$ & $118.13 \%$ & $166.41 \%$ & $91.84 \%$ & $134.78 \%$ \\
\hline FactorAverage & $20.98 \%$ & $15.23 \%$ & $21.46 \%$ & $11.84 \%$ & \\
\hline
\end{tabular}

Panel B. Buyers' $\Delta$ YTM_SCORE_50

\begin{tabular}{llllll}
\hline & CPN & CPN $\times$ CRD & TRI & MAT & Country Average \\
\hline Australia & $1.30 \%$ & $1.10 \%$ & $0.60 \%$ & $4.56 \%$ & $1.89 \%$ \\
Austria & $1.18 \%$ & $1.00 \%$ & $0.54 \%$ & $4.15 \%$ & $1.72 \%$ \\
Belgium & $0.91 \%$ & $0.77 \%$ & $0.42 \%$ & $3.20 \%$ & $1.32 \%$ \\
Brazil & $16.15 \%$ & $13.65 \%$ & $7.45 \%$ & $56.80 \%$ & $23.51 \%$ \\
China & $372.40 \%$ & $314.66 \%$ & $171.81 \%$ & $1309.71 \%$ & $542.14 \%$ \\
Colombia & $0.11 \%$ & $0.09 \%$ & $0.05 \%$ & $0.37 \%$ & $0.15 \%$ \\
Croatia & $0.00 \%$ & $0.00 \%$ & $0.00 \%$ & $0.01 \%$ & $0.00 \%$ \\
Cyprus & $0.07 \%$ & $0.06 \%$ & $0.03 \%$ & $0.25 \%$ & $0.10 \%$ \\
Czech & $0.01 \%$ & $0.01 \%$ & $0.01 \%$ & $0.05 \%$ & $0.02 \%$ \\
Denmark & $2.49 \%$ & $2.10 \%$ & $1.15 \%$ & $8.76 \%$ & $3.63 \%$ \\
Estonia & $0.00 \%$ & $0.00 \%$ & $0.00 \%$ & $0.00 \%$ & $0.00 \%$ \\
Finland & $2.79 \%$ & $2.36 \%$ & $1.29 \%$ & $9.80 \%$ & $4.06 \%$ \\
France & $84.31 \%$ & $71.23 \%$ & $38.90 \%$ & $296.50 \%$ & $122.73 \%$ \\
Georgia & $0.04 \%$ & $0.04 \%$ & $0.02 \%$ & $0.15 \%$ & $0.06 \%$ \\
Germany & $4.56 \%$ & $3.85 \%$ & $2.10 \%$ & $16.04 \%$ & $6.64 \%$
\end{tabular}


Global CoCo bond buyers' YTM_SCORE preference scores with incremental factor change (continued)

\begin{tabular}{|c|c|c|c|c|c|}
\hline \multicolumn{6}{|c|}{ Panel B. Buyers' $\Delta$ YTM_SCORE_50 } \\
\hline & $\mathrm{CPN}$ & $\mathrm{CPN} \times \mathrm{CRD}$ & TRI & MAT & Country Average \\
\hline Hungary & $0.00 \%$ & $0.00 \%$ & $0.00 \%$ & $0.02 \%$ & $0.01 \%$ \\
\hline India & $2.42 \%$ & $2.04 \%$ & $1.12 \%$ & $8.51 \%$ & $3.52 \%$ \\
\hline Indonesia & $0.00 \%$ & $0.00 \%$ & $0.00 \%$ & $0.00 \%$ & $0.00 \%$ \\
\hline Ireland & $0.53 \%$ & $0.45 \%$ & $0.24 \%$ & $1.87 \%$ & $0.77 \%$ \\
\hline Israel & $0.31 \%$ & $0.27 \%$ & $0.15 \%$ & $1.11 \%$ & $0.46 \%$ \\
\hline Italy & $10.88 \%$ & $9.20 \%$ & $5.02 \%$ & $38.28 \%$ & $15.85 \%$ \\
\hline Japan & $34.29 \%$ & $28.98 \%$ & $15.82 \%$ & $120.61 \%$ & $49.93 \%$ \\
\hline Luxembourg & $0.01 \%$ & $0.01 \%$ & $0.01 \%$ & $0.05 \%$ & $0.02 \%$ \\
\hline Malaysia & $1.61 \%$ & $1.36 \%$ & $0.74 \%$ & $5.65 \%$ & $2.34 \%$ \\
\hline Mexico & $10.07 \%$ & $8.51 \%$ & $4.64 \%$ & $35.40 \%$ & $14.65 \%$ \\
\hline Netherlands & $10.44 \%$ & $8.82 \%$ & $4.82 \%$ & $36.73 \%$ & $15.20 \%$ \\
\hline New Zealand & $0.00 \%$ & $0.00 \%$ & $0.00 \%$ & $0.02 \%$ & $0.01 \%$ \\
\hline Norway & $2.50 \%$ & $2.11 \%$ & $1.15 \%$ & $8.78 \%$ & $3.64 \%$ \\
\hline Portugal & $0.30 \%$ & $0.26 \%$ & $0.14 \%$ & $1.07 \%$ & $0.44 \%$ \\
\hline Russia & $19.65 \%$ & $16.61 \%$ & $9.07 \%$ & $69.12 \%$ & $28.61 \%$ \\
\hline Slovakia & $0.00 \%$ & $0.00 \%$ & $0.00 \%$ & $0.02 \%$ & $0.01 \%$ \\
\hline South Africa & $0.01 \%$ & $0.01 \%$ & $0.01 \%$ & $0.05 \%$ & $0.02 \%$ \\
\hline Spain & $29.41 \%$ & $24.85 \%$ & $13.57 \%$ & $103.42 \%$ & $42.81 \%$ \\
\hline Sweden & $2.95 \%$ & $2.50 \%$ & $1.36 \%$ & $10.39 \%$ & $4.30 \%$ \\
\hline Switzerland & $119.64 \%$ & $101.09 \%$ & $55.20 \%$ & $420.78 \%$ & $174.18 \%$ \\
\hline Turkey & $0.11 \%$ & $0.09 \%$ & $0.05 \%$ & $0.38 \%$ & $0.16 \%$ \\
\hline United Kingdom & $193.99 \%$ & $163.91 \%$ & $89.50 \%$ & $682.25 \%$ & $282.41 \%$ \\
\hline FactorAverage & $25.01 \%$ & $21.13 \%$ & $11.54 \%$ & $87.97 \%$ & \\
\hline
\end{tabular}




\begin{tabular}{|c|c|c|c|c|c|c|c|c|c|c|c|c|c|c|}
\hline \multicolumn{15}{|c|}{ Panel C. Buyers' $\Delta$ YTM_SCORE_75 } \\
\hline & CPN & $\mathrm{CPN} \times \mathrm{CRD}$ & TRI & $\mathrm{CON}$ & CRD & MAT & AMT & AMT $\times$ ROE & CDS & $\mathrm{P} / \mathrm{B}$ & SIZE & TRC/RWA & CPI & Country Average \\
\hline Australia & $1.53 \%$ & $1.00 \%$ & $0.89 \%$ & $0.43 \%$ & $1.38 \%$ & $0.00 \%$ & $0.67 \%$ & $1.16 \%$ & $0.96 \%$ & $1.31 \%$ & $1.25 \%$ & $1.28 \%$ & $0.86 \%$ & $0.98 \%$ \\
\hline Austria & $1.39 \%$ & $0.91 \%$ & $0.81 \%$ & $0.39 \%$ & $1.25 \%$ & $0.00 \%$ & $0.61 \%$ & $1.05 \%$ & $0.88 \%$ & $1.19 \%$ & $1.14 \%$ & $1.17 \%$ & $0.78 \%$ & $0.89 \%$ \\
\hline Belgium & $1.07 \%$ & $0.70 \%$ & $0.62 \%$ & $0.30 \%$ & $0.96 \%$ & $0.00 \%$ & $0.47 \%$ & $0.81 \%$ & $0.68 \%$ & $0.92 \%$ & $0.88 \%$ & $0.90 \%$ & $0.60 \%$ & $0.69 \%$ \\
\hline Brazil & $19.08 \%$ & $12.48 \%$ & $11.07 \%$ & $5.36 \%$ & $17.13 \%$ & $0.00 \%$ & $8.37 \%$ & $14.41 \%$ & $12.00 \%$ & $16.31 \%$ & $15.55 \%$ & $15.95 \%$ & $10.67 \%$ & $12.18 \%$ \\
\hline China & $439.88 \%$ & $287.79 \%$ & $255.29 \%$ & $123.56 \%$ & $394.91 \%$ & $0.03 \%$ & $192.96 \%$ & $332.30 \%$ & $276.78 \%$ & $376.05 \%$ & $358.53 \%$ & $367.78 \%$ & $246.04 \%$ & $280.92 \%$ \\
\hline Colombia & $0.12 \%$ & $0.08 \%$ & $0.07 \%$ & $0.03 \%$ & $0.11 \%$ & $0.00 \%$ & $0.05 \%$ & $0.09 \%$ & $0.08 \%$ & $0.11 \%$ & $0.10 \%$ & $0.10 \%$ & $0.07 \%$ & $0.08 \%$ \\
\hline Croatia & $0.00 \%$ & $0.00 \%$ & $0.00 \%$ & $0.00 \%$ & $0.00 \%$ & $0.00 \%$ & $0.00 \%$ & $0.00 \%$ & $0.00 \%$ & $0.00 \%$ & $0.00 \%$ & $0.00 \%$ & $0.00 \%$ & $0.00 \%$ \\
\hline Cyprus & $0.08 \%$ & $0.06 \%$ & $0.05 \%$ & $0.02 \%$ & $0.08 \%$ & $0.00 \%$ & $0.04 \%$ & $0.06 \%$ & $0.05 \%$ & $0.07 \%$ & $0.07 \%$ & $0.07 \%$ & $0.05 \%$ & $0.05 \%$ \\
\hline Czech & $0.02 \%$ & $0.01 \%$ & $0.01 \%$ & $0.00 \%$ & $0.01 \%$ & $0.00 \%$ & $0.01 \%$ & $0.01 \%$ & $0.01 \%$ & $0.01 \%$ & $0.01 \%$ & $0.01 \%$ & $0.01 \%$ & $0.01 \%$ \\
\hline Denmark & $2.94 \%$ & $1.92 \%$ & $1.71 \%$ & $0.83 \%$ & $2.64 \%$ & $0.00 \%$ & $1.29 \%$ & $2.22 \%$ & $1.85 \%$ & $2.51 \%$ & $2.40 \%$ & $2.46 \%$ & $1.65 \%$ & $1.88 \%$ \\
\hline Estonia & $0.00 \%$ & $0.00 \%$ & $0.00 \%$ & $0.00 \%$ & $0.00 \%$ & $0.00 \%$ & $0.00 \%$ & $0.00 \%$ & $0.00 \%$ & $0.00 \%$ & $0.00 \%$ & $0.00 \%$ & $0.00 \%$ & $0.00 \%$ \\
\hline Finland & $3.29 \%$ & $2.15 \%$ & $1.91 \%$ & $0.92 \%$ & $2.96 \%$ & $0.00 \%$ & $1.44 \%$ & $2.49 \%$ & $2.07 \%$ & $2.82 \%$ & $2.68 \%$ & $2.75 \%$ & $1.84 \%$ & $2.10 \%$ \\
\hline France & $99.58 \%$ & $65.15 \%$ & $57.79 \%$ & $27.97 \%$ & $89.40 \%$ & $0.01 \%$ & $43.68 \%$ & $75.23 \%$ & $62.66 \%$ & $85.13 \%$ & $81.17 \%$ & $83.26 \%$ & $55.70 \%$ & $63.60 \%$ \\
\hline Georgia & $0.05 \%$ & $0.03 \%$ & $0.03 \%$ & $0.01 \%$ & $0.05 \%$ & $0.00 \%$ & $0.02 \%$ & $0.04 \%$ & $0.03 \%$ & $0.04 \%$ & $0.04 \%$ & $0.04 \%$ & $0.03 \%$ & $0.03 \%$ \\
\hline Germany & $5.39 \%$ & $3.52 \%$ & $3.13 \%$ & $1.51 \%$ & $4.84 \%$ & $0.00 \%$ & $2.36 \%$ & $4.07 \%$ & $3.39 \%$ & $4.61 \%$ & $4.39 \%$ & $4.50 \%$ & $3.01 \%$ & $3.44 \%$ \\
\hline Hungary & $0.01 \%$ & $0.00 \%$ & $0.00 \%$ & $0.00 \%$ & $0.00 \%$ & $0.00 \%$ & $0.00 \%$ & $0.00 \%$ & $0.00 \%$ & $0.00 \%$ & $0.00 \%$ & $0.00 \%$ & $0.00 \%$ & $0.00 \%$ \\
\hline India & $2.86 \%$ & $1.87 \%$ & $1.66 \%$ & $0.80 \%$ & $2.57 \%$ & $0.00 \%$ & $1.25 \%$ & $2.16 \%$ & $1.80 \%$ & $2.44 \%$ & $2.33 \%$ & $2.39 \%$ & $1.60 \%$ & $1.83 \%$ \\
\hline Indonesia & $0.00 \%$ & $0.00 \%$ & $0.00 \%$ & $0.00 \%$ & $0.00 \%$ & $0.00 \%$ & $0.00 \%$ & $0.00 \%$ & $0.00 \%$ & $0.00 \%$ & $0.00 \%$ & $0.00 \%$ & $0.00 \%$ & $0.00 \%$ \\
\hline Ireland & $0.63 \%$ & $0.41 \%$ & $0.36 \%$ & $0.18 \%$ & $0.56 \%$ & $0.00 \%$ & $0.27 \%$ & $0.47 \%$ & $0.39 \%$ & $0.54 \%$ & $0.51 \%$ & $0.52 \%$ & $0.35 \%$ & $0.40 \%$ \\
\hline Israel & $0.37 \%$ & $0.24 \%$ & $0.22 \%$ & $0.10 \%$ & $0.33 \%$ & $0.00 \%$ & $0.16 \%$ & $0.28 \%$ & $0.23 \%$ & $0.32 \%$ & $0.30 \%$ & $0.31 \%$ & $0.21 \%$ & $0.24 \%$ \\
\hline Italy & $12.86 \%$ & $8.41 \%$ & $7.46 \%$ & $3.61 \%$ & $11.54 \%$ & $0.00 \%$ & $5.64 \%$ & $9.71 \%$ & $8.09 \%$ & $10.99 \%$ & $10.48 \%$ & $10.75 \%$ & $7.19 \%$ & $8.21 \%$ \\
\hline Japan & $40.51 \%$ & $26.50 \%$ & $23.51 \%$ & $11.38 \%$ & $36.37 \%$ & $0.00 \%$ & $17.77 \%$ & $30.60 \%$ & $25.49 \%$ & $34.63 \%$ & $33.02 \%$ & $33.87 \%$ & $22.66 \%$ & $25.87 \%$ \\
\hline Luxembourg & $0.02 \%$ & $0.01 \%$ & $0.01 \%$ & $0.00 \%$ & $0.01 \%$ & $0.00 \%$ & $0.01 \%$ & $0.01 \%$ & $0.01 \%$ & $0.01 \%$ & $0.01 \%$ & $0.01 \%$ & $0.01 \%$ & $0.01 \%$ \\
\hline Malaysia & $1.90 \%$ & $1.24 \%$ & $1.10 \%$ & $0.53 \%$ & $1.70 \%$ & $0.00 \%$ & $0.83 \%$ & $1.43 \%$ & $1.19 \%$ & $1.62 \%$ & $1.55 \%$ & $1.59 \%$ & $1.06 \%$ & $1.21 \%$ \\
\hline Mexico & $11.89 \%$ & $7.78 \%$ & $6.90 \%$ & $3.34 \%$ & $10.67 \%$ & $0.00 \%$ & $5.22 \%$ & $8.98 \%$ & $7.48 \%$ & $10.16 \%$ & $9.69 \%$ & $9.94 \%$ & $6.65 \%$ & $7.59 \%$ \\
\hline Netherlands & $12.34 \%$ & $8.07 \%$ & $7.16 \%$ & $3.47 \%$ & $11.08 \%$ & $0.00 \%$ & $5.41 \%$ & $9.32 \%$ & $7.76 \%$ & $10.55 \%$ & $10.05 \%$ & $10.31 \%$ & $6.90 \%$ & $7.88 \%$ \\
\hline New Zealand & $0.01 \%$ & $0.00 \%$ & $0.00 \%$ & $0.00 \%$ & $0.00 \%$ & $0.00 \%$ & $0.00 \%$ & $0.00 \%$ & $0.00 \%$ & $0.00 \%$ & $0.00 \%$ & $0.00 \%$ & $0.00 \%$ & $0.00 \%$ \\
\hline Norway & $2.95 \%$ & $1.93 \%$ & $1.71 \%$ & $0.83 \%$ & $2.65 \%$ & $0.00 \%$ & $1.29 \%$ & $2.23 \%$ & $1.86 \%$ & $2.52 \%$ & $2.40 \%$ & $2.47 \%$ & $1.65 \%$ & $1.88 \%$ \\
\hline Portugal & $0.36 \%$ & $0.24 \%$ & $0.21 \%$ & $0.10 \%$ & $0.32 \%$ & $0.00 \%$ & $0.16 \%$ & $0.27 \%$ & $0.23 \%$ & $0.31 \%$ & $0.29 \%$ & $0.30 \%$ & $0.20 \%$ & $0.23 \%$ \\
\hline Russia & $23.22 \%$ & $15.19 \%$ & $13.47 \%$ & $6.52 \%$ & $20.84 \%$ & $0.00 \%$ & $10.18 \%$ & $17.54 \%$ & $14.61 \%$ & $19.85 \%$ & $18.92 \%$ & $19.41 \%$ & $12.99 \%$ & $14.83 \%$ \\
\hline Slovakia & $0.01 \%$ & $0.00 \%$ & $0.00 \%$ & $0.00 \%$ & $0.01 \%$ & $0.00 \%$ & $0.00 \%$ & $0.00 \%$ & $0.00 \%$ & $0.00 \%$ & $0.00 \%$ & $0.00 \%$ & $0.00 \%$ & $0.00 \%$ \\
\hline South Africa & $0.02 \%$ & $0.01 \%$ & $0.01 \%$ & $0.00 \%$ & $0.01 \%$ & $0.00 \%$ & $0.01 \%$ & $0.01 \%$ & $0.01 \%$ & $0.01 \%$ & $0.01 \%$ & $0.01 \%$ & $0.01 \%$ & $0.01 \%$ \\
\hline Spain & $34.73 \%$ & $22.72 \%$ & $20.16 \%$ & $9.76 \%$ & $31.18 \%$ & $0.00 \%$ & $15.24 \%$ & $26.24 \%$ & $21.86 \%$ & $29.69 \%$ & $28.31 \%$ & $29.04 \%$ & $19.43 \%$ & $22.18 \%$ \\
\hline Sweden & $3.49 \%$ & $2.28 \%$ & $2.03 \%$ & $0.98 \%$ & $3.13 \%$ & $0.00 \%$ & $1.53 \%$ & $2.64 \%$ & $2.20 \%$ & $2.98 \%$ & $2.84 \%$ & $2.92 \%$ & $1.95 \%$ & $2.23 \%$ \\
\hline Switzerland & $141.33 \%$ & $92.46 \%$ & $82.02 \%$ & $39.70 \%$ & $126.88 \%$ & $0.01 \%$ & $62.00 \%$ & $106.76 \%$ & $88.92 \%$ & $120.82 \%$ & $115.19 \%$ & $118.16 \%$ & $79.05 \%$ & $90.25 \%$ \\
\hline Turkey & $0.13 \%$ & $0.08 \%$ & $0.07 \%$ & $0.04 \%$ & $0.11 \%$ & $0.00 \%$ & $0.06 \%$ & $0.10 \%$ & $0.08 \%$ & $0.11 \%$ & $0.10 \%$ & $0.11 \%$ & $0.07 \%$ & $0.08 \%$ \\
\hline United Kingdom & $229.14 \%$ & $149.91 \%$ & $132.98 \%$ & $64.36 \%$ & $205.72 \%$ & $0.01 \%$ & $100.52 \%$ & $173.10 \%$ & $144.18 \%$ & $195.89 \%$ & $186.76 \%$ & $191.58 \%$ & $128.17 \%$ & $146.33 \%$ \\
\hline Factor Average & $29.55 \%$ & $19.33 \%$ & $17.15 \%$ & $8.30 \%$ & $26.53 \%$ & $0.00 \%$ & $12.96 \%$ & $22.32 \%$ & $18.59 \%$ & $25.26 \%$ & $24.08 \%$ & $24.70 \%$ & $16.53 \%$ & \\
\hline
\end{tabular}




\section{Appendix D. Global CoCo bond sellers' YTC_SCORE preference scores with incremental factor change}

The following tables present the incremental change in CoCo bond's global preference scores based on the 25th, 50th and 75th percentile benchmarks of YTC_SCORE in Panel A ( $\triangle$ YTC_SCORE_25), B ( $\Delta$ YTC_SCORE_50) and C ( $\Delta$ YTC_SCORE_75), respectively. We provide the global preference scores with the incremental changes in significant factors in Table 3 and 4. The preference scores are scaled by the market power score for each country to provide country specific preference scores as in our equation (8) and (9). We report the country and factor average preference responses which are the average values across each row and column, respectively.

\begin{tabular}{|c|c|c|c|}
\hline \multicolumn{4}{|c|}{ Panel A. Sellers' $\Delta$ YTC_SCORE_25 } \\
\hline & CPN & $\mathrm{CPN} \times \mathrm{CRD}$ & $\begin{array}{l}\text { Country } \\
\text { Average }\end{array}$ \\
\hline Australia & $1.23 \%$ & $1.09 \%$ & $1.16 \%$ \\
\hline Austria & $1.12 \%$ & $0.99 \%$ & $1.06 \%$ \\
\hline Belgium & $0.87 \%$ & $0.76 \%$ & $0.81 \%$ \\
\hline Brazil & $15.38 \%$ & $13.53 \%$ & $14.46 \%$ \\
\hline China & $354.69 \%$ & $311.91 \%$ & $333.30 \%$ \\
\hline Colombia & $0.10 \%$ & $0.09 \%$ & $0.09 \%$ \\
\hline Croatia & $0.00 \%$ & $0.00 \%$ & $0.00 \%$ \\
\hline Cyprus & $0.07 \%$ & $0.06 \%$ & $0.06 \%$ \\
\hline Czech & $0.01 \%$ & $0.01 \%$ & $0.01 \%$ \\
\hline Denmark & $2.37 \%$ & $2.09 \%$ & $2.23 \%$ \\
\hline Estonia & $0.00 \%$ & $0.00 \%$ & $0.00 \%$ \\
\hline Finland & $2.66 \%$ & $2.34 \%$ & $2.50 \%$ \\
\hline France & $80.30 \%$ & $70.61 \%$ & $75.45 \%$ \\
\hline Georgia & $0.04 \%$ & $0.04 \%$ & $0.04 \%$ \\
\hline Germany & $4.34 \%$ & $3.82 \%$ & $4.08 \%$ \\
\hline Hungary & $0.00 \%$ & $0.00 \%$ & $0.00 \%$ \\
\hline India & $2.30 \%$ & $2.03 \%$ & $2.17 \%$ \\
\hline Indonesia & $0.00 \%$ & $0.00 \%$ & $0.00 \%$ \\
\hline Ireland & $0.51 \%$ & $0.44 \%$ & $0.47 \%$ \\
\hline Israel & $0.30 \%$ & $0.26 \%$ & $0.28 \%$ \\
\hline Italy & $10.37 \%$ & $9.12 \%$ & $9.74 \%$ \\
\hline Japan & $32.66 \%$ & $28.72 \%$ & $30.69 \%$ \\
\hline Luxembourg & $0.01 \%$ & $0.01 \%$ & $0.01 \%$ \\
\hline Malaysia & $1.53 \%$ & $1.34 \%$ & $1.44 \%$ \\
\hline Mexico & $9.59 \%$ & $8.43 \%$ & $9.01 \%$ \\
\hline Netherlands & $9.95 \%$ & $8.75 \%$ & $9.35 \%$ \\
\hline New Zealand & $0.00 \%$ & $0.00 \%$ & $0.00 \%$ \\
\hline Norway & $2.38 \%$ & $2.09 \%$ & $2.24 \%$ \\
\hline Portugal & $0.29 \%$ & $0.26 \%$ & $0.27 \%$ \\
\hline Russia & $18.72 \%$ & $16.46 \%$ & $17.59 \%$ \\
\hline Slovakia & $0.00 \%$ & $0.00 \%$ & $0.00 \%$ \\
\hline South Africa & $0.01 \%$ & $0.01 \%$ & $0.01 \%$ \\
\hline Spain & $28.01 \%$ & $24.63 \%$ & $26.32 \%$ \\
\hline Sweden & $2.81 \%$ & $2.47 \%$ & $2.64 \%$ \\
\hline Switzerland & $113.95 \%$ & $100.21 \%$ & $107.08 \%$ \\
\hline Turkey & $0.10 \%$ & $0.09 \%$ & $0.10 \%$ \\
\hline United Kingdom & $184.76 \%$ & $162.48 \%$ & $173.62 \%$ \\
\hline Factor Average & $23.82 \%$ & $20.95 \%$ & \\
\hline
\end{tabular}




\begin{tabular}{|c|c|c|c|c|c|c|c|}
\hline \multicolumn{8}{|c|}{ Panel B. Sellers' $\Delta$ YTC_SCORE_50 } \\
\hline & CPN & $\mathrm{CPN} \times \mathrm{CRD}$ & TRI & $\mathrm{CON}$ & MAT & CDS & Country Average \\
\hline Australia & $1.21 \%$ & $1.11 \%$ & $0.69 \%$ & $0.68 \%$ & $4.56 \%$ & $1.01 \%$ & $1.54 \%$ \\
\hline Austria & $1.10 \%$ & $1.01 \%$ & $0.63 \%$ & $0.62 \%$ & $4.15 \%$ & $0.92 \%$ & $1.40 \%$ \\
\hline Belgium & $0.85 \%$ & $0.78 \%$ & $0.48 \%$ & $0.48 \%$ & $3.20 \%$ & $0.71 \%$ & $1.08 \%$ \\
\hline Brazil & $15.02 \%$ & $13.77 \%$ & $8.61 \%$ & $8.51 \%$ & $56.80 \%$ & $12.52 \%$ & $19.21 \%$ \\
\hline China & $346.37 \%$ & $317.43 \%$ & $198.46 \%$ & $196.31 \%$ & $1309.75 \%$ & $288.79 \%$ & $442.85 \%$ \\
\hline Colombia & $0.10 \%$ & $0.09 \%$ & $0.06 \%$ & $0.06 \%$ & $0.37 \%$ & $0.08 \%$ & $0.12 \%$ \\
\hline Croatia & $0.00 \%$ & $0.00 \%$ & $0.00 \%$ & $0.00 \%$ & $0.01 \%$ & $0.00 \%$ & $0.00 \%$ \\
\hline Cyprus & $0.07 \%$ & $0.06 \%$ & $0.04 \%$ & $0.04 \%$ & $0.25 \%$ & $0.06 \%$ & $0.09 \%$ \\
\hline Czech & $0.01 \%$ & $0.01 \%$ & $0.01 \%$ & $0.01 \%$ & $0.05 \%$ & $0.01 \%$ & $0.02 \%$ \\
\hline Denmark & $2.32 \%$ & $2.12 \%$ & $1.33 \%$ & $1.31 \%$ & $8.76 \%$ & $1.93 \%$ & $2.96 \%$ \\
\hline Estonia & $0.00 \%$ & $0.00 \%$ & $0.00 \%$ & $0.00 \%$ & $0.00 \%$ & $0.00 \%$ & $0.00 \%$ \\
\hline Finland & $2.59 \%$ & $2.38 \%$ & $1.49 \%$ & $1.47 \%$ & $9.80 \%$ & $2.16 \%$ & $3.32 \%$ \\
\hline France & $78.41 \%$ & $71.86 \%$ & $44.93 \%$ & $44.44 \%$ & $296.51 \%$ & $65.38 \%$ & $100.26 \%$ \\
\hline Georgia & $0.04 \%$ & $0.04 \%$ & $0.02 \%$ & $0.02 \%$ & $0.15 \%$ & $0.03 \%$ & $0.05 \%$ \\
\hline Germany & $4.24 \%$ & $3.89 \%$ & $2.43 \%$ & $2.40 \%$ & $16.04 \%$ & $3.54 \%$ & $5.42 \%$ \\
\hline Hungary & $0.00 \%$ & $0.00 \%$ & $0.00 \%$ & $0.00 \%$ & $0.02 \%$ & $0.00 \%$ & $0.01 \%$ \\
\hline India & $2.25 \%$ & $2.06 \%$ & $1.29 \%$ & $1.28 \%$ & $8.51 \%$ & $1.88 \%$ & $2.88 \%$ \\
\hline Indonesia & $0.00 \%$ & $0.00 \%$ & $0.00 \%$ & $0.00 \%$ & $0.00 \%$ & $0.00 \%$ & $0.00 \%$ \\
\hline Ireland & $0.49 \%$ & $0.45 \%$ & $0.28 \%$ & $0.28 \%$ & $1.87 \%$ & $0.41 \%$ & $0.63 \%$ \\
\hline Israel & $0.29 \%$ & $0.27 \%$ & $0.17 \%$ & $0.17 \%$ & $1.11 \%$ & $0.24 \%$ & $0.37 \%$ \\
\hline Italy & $10.12 \%$ & $9.28 \%$ & $5.80 \%$ & $5.74 \%$ & $38.28 \%$ & $8.44 \%$ & $12.94 \%$ \\
\hline Japan & $31.90 \%$ & $29.23 \%$ & $18.28 \%$ & $18.08 \%$ & $120.62 \%$ & $26.60 \%$ & $40.78 \%$ \\
\hline Luxembourg & $0.01 \%$ & $0.01 \%$ & $0.01 \%$ & $0.01 \%$ & $0.05 \%$ & $0.01 \%$ & $0.02 \%$ \\
\hline Malaysia & $1.49 \%$ & $1.37 \%$ & $0.86 \%$ & $0.85 \%$ & $5.65 \%$ & $1.24 \%$ & $1.91 \%$ \\
\hline Mexico & $9.36 \%$ & $8.58 \%$ & $5.36 \%$ & $5.31 \%$ & $35.40 \%$ & $7.81 \%$ & $11.97 \%$ \\
\hline Netherlands & $9.71 \%$ & $8.90 \%$ & $5.57 \%$ & $5.51 \%$ & $36.73 \%$ & $8.10 \%$ & $12.42 \%$ \\
\hline New Zealand & $0.00 \%$ & $0.00 \%$ & $0.00 \%$ & $0.00 \%$ & $0.02 \%$ & $0.00 \%$ & $0.01 \%$ \\
\hline Norway & $2.32 \%$ & $2.13 \%$ & $1.33 \%$ & $1.32 \%$ & $8.78 \%$ & $1.94 \%$ & $2.97 \%$ \\
\hline Portugal & $0.28 \%$ & $0.26 \%$ & $0.16 \%$ & $0.16 \%$ & $1.07 \%$ & $0.24 \%$ & $0.36 \%$ \\
\hline Russia & $18.28 \%$ & $16.75 \%$ & $10.47 \%$ & $10.36 \%$ & $69.12 \%$ & $15.24 \%$ & $23.37 \%$ \\
\hline Slovakia & $0.00 \%$ & $0.00 \%$ & $0.00 \%$ & $0.00 \%$ & $0.02 \%$ & $0.00 \%$ & $0.01 \%$ \\
\hline South Africa & $0.01 \%$ & $0.01 \%$ & $0.01 \%$ & $0.01 \%$ & $0.05 \%$ & $0.01 \%$ & $0.02 \%$ \\
\hline Spain & $27.35 \%$ & $25.06 \%$ & $15.67 \%$ & $15.50 \%$ & $103.42 \%$ & $22.80 \%$ & $34.97 \%$ \\
\hline Sweden & $2.75 \%$ & $2.52 \%$ & $1.57 \%$ & $1.56 \%$ & $10.39 \%$ & $2.29 \%$ & $3.51 \%$ \\
\hline Switzerland & $111.28 \%$ & $101.98 \%$ & $63.76 \%$ & $63.07 \%$ & $420.80 \%$ & $92.78 \%$ & $142.28 \%$ \\
\hline Turkey & $0.10 \%$ & $0.09 \%$ & $0.06 \%$ & $0.06 \%$ & $0.38 \%$ & $0.08 \%$ & $0.13 \%$ \\
\hline United Kingdom & $180.43 \%$ & $165.35 \%$ & $103.38 \%$ & $102.26 \%$ & $682.27 \%$ & $150.44 \%$ & $230.69 \%$ \\
\hline Factor Average & $23.26 \%$ & $21.32 \%$ & $13.33 \%$ & $13.19 \%$ & $87.97 \%$ & $19.40 \%$ & \\
\hline
\end{tabular}

\begin{tabular}{|c|c|c|c|c|c|c|c|c|c|c|}
\hline \multicolumn{11}{|c|}{ Panel C. Sellers' $\triangle$ YTC_SCORE_75 } \\
\hline & CPN & $\begin{array}{l}\mathrm{CPN} \times \\
\mathrm{CRD}\end{array}$ & TRI & CON & AMT & $\begin{array}{l}\text { AMT } \times \\
\text { ROE }\end{array}$ & CDS & $\mathrm{P} / \mathrm{B}$ & $\begin{array}{l}\text { TRC/ } \\
\text { RWA }\end{array}$ & $\begin{array}{l}\text { Country } \\
\text { Average }\end{array}$ \\
\hline Australia & $1.48 \%$ & $1.01 \%$ & $0.95 \%$ & $0.46 \%$ & $0.65 \%$ & $1.16 \%$ & $0.94 \%$ & $1.39 \%$ & $1.28 \%$ & $1.03 \%$ \\
\hline Austria & $1.34 \%$ & $0.92 \%$ & $0.86 \%$ & $0.42 \%$ & $0.59 \%$ & $1.05 \%$ & $0.85 \%$ & $1.27 \%$ & $1.17 \%$ & $0.94 \%$ \\
\hline Belgium & $1.04 \%$ & $0.71 \%$ & $0.66 \%$ & $0.32 \%$ & $0.46 \%$ & $0.81 \%$ & $0.66 \%$ & $0.98 \%$ & $0.90 \%$ & $0.73 \%$ \\
\hline Brazil & $18.38 \%$ & $12.62 \%$ & $11.79 \%$ & $5.69 \%$ & $8.09 \%$ & $14.42 \%$ & $11.65 \%$ & $17.37 \%$ & $15.99 \%$ & $12.89 \%$ \\
\hline China & $423.87 \%$ & $291.04 \%$ & $271.78 \%$ & $131.19 \%$ & $186.50 \%$ & $332.54 \%$ & $268.71 \%$ & $400.58 \%$ & $368.69 \%$ & $297.21 \%$ \\
\hline Colombia & $0.12 \%$ & $0.08 \%$ & $0.08 \%$ & $0.04 \%$ & $0.05 \%$ & $0.09 \%$ & $0.08 \%$ & $0.11 \%$ & $0.10 \%$ & $0.08 \%$ \\
\hline Croatia & $0.00 \%$ & $0.00 \%$ & $0.00 \%$ & $0.00 \%$ & $0.00 \%$ & $0.00 \%$ & $0.00 \%$ & $0.00 \%$ & $0.00 \%$ & $0.00 \%$ \\
\hline Cyprus & $0.08 \%$ & $0.06 \%$ & $0.05 \%$ & $0.03 \%$ & $0.04 \%$ & $0.06 \%$ & $0.05 \%$ & $0.08 \%$ & $0.07 \%$ & $0.06 \%$ \\
\hline Czech & $0.02 \%$ & $0.01 \%$ & $0.01 \%$ & $0.00 \%$ & $0.01 \%$ & $0.01 \%$ & $0.01 \%$ & $0.02 \%$ & $0.01 \%$ & $0.01 \%$ \\
\hline Denmark & $2.83 \%$ & $1.95 \%$ & $1.82 \%$ & $0.88 \%$ & $1.25 \%$ & $2.22 \%$ & $1.80 \%$ & $2.68 \%$ & $2.47 \%$ & $1.99 \%$ \\
\hline
\end{tabular}


Global CoCo bond sellers' YTC_SCORE preference scores with incremental factor change (continued)

\begin{tabular}{|c|c|c|c|c|c|c|c|c|c|c|}
\hline \multicolumn{11}{|c|}{ Panel C. Sellers' $\Delta$ YTC_SCORE_75 } \\
\hline & CPN & $\begin{array}{l}\mathrm{CPN} \times \\
\mathrm{CRD}\end{array}$ & TRI & CON & AMT & $\begin{array}{l}\text { AMT } \times \\
\text { ROE }\end{array}$ & CDS & $\mathrm{P} / \mathrm{B}$ & $\begin{array}{l}\text { TRC/ } \\
\text { RWA }\end{array}$ & $\begin{array}{l}\text { Country } \\
\text { Average }\end{array}$ \\
\hline Estonia & $0.00 \%$ & $0.00 \%$ & $0.00 \%$ & $0.00 \%$ & $0.00 \%$ & $0.00 \%$ & $0.00 \%$ & $0.00 \%$ & $0.00 \%$ & $0.00 \%$ \\
\hline Finland & $3.17 \%$ & $2.18 \%$ & $2.03 \%$ & $0.98 \%$ & $1.40 \%$ & $2.49 \%$ & $2.01 \%$ & $3.00 \%$ & $2.76 \%$ & $2.22 \%$ \\
\hline France & $95.96 \%$ & $65.89 \%$ & $61.53 \%$ & $29.70 \%$ & $42.22 \%$ & $75.28 \%$ & $60.83 \%$ & $90.69 \%$ & $83.47 \%$ & $67.29 \%$ \\
\hline Georgia & $0.05 \%$ & $0.03 \%$ & $0.03 \%$ & $0.02 \%$ & $0.02 \%$ & $0.04 \%$ & $0.03 \%$ & $0.05 \%$ & $0.04 \%$ & $0.03 \%$ \\
\hline Germany & $5.19 \%$ & $3.56 \%$ & $3.33 \%$ & $1.61 \%$ & $2.28 \%$ & $4.07 \%$ & $3.29 \%$ & $4.91 \%$ & $4.52 \%$ & $3.64 \%$ \\
\hline Hungary & $0.01 \%$ & $0.00 \%$ & $0.00 \%$ & $0.00 \%$ & $0.00 \%$ & $0.00 \%$ & $0.00 \%$ & $0.01 \%$ & $0.00 \%$ & $0.00 \%$ \\
\hline India & $2.75 \%$ & $1.89 \%$ & $1.77 \%$ & $0.85 \%$ & $1.21 \%$ & $2.16 \%$ & $1.75 \%$ & $2.60 \%$ & $2.40 \%$ & $1.93 \%$ \\
\hline Indonesia & $0.00 \%$ & $0.00 \%$ & $0.00 \%$ & $0.00 \%$ & $0.00 \%$ & $0.00 \%$ & $0.00 \%$ & $0.00 \%$ & $0.00 \%$ & $0.00 \%$ \\
\hline Ireland & $0.60 \%$ & $0.41 \%$ & $0.39 \%$ & $0.19 \%$ & $0.27 \%$ & $0.47 \%$ & $0.38 \%$ & $0.57 \%$ & $0.53 \%$ & $0.42 \%$ \\
\hline Israel & $0.36 \%$ & $0.25 \%$ & $0.23 \%$ & $0.11 \%$ & $0.16 \%$ & $0.28 \%$ & $0.23 \%$ & $0.34 \%$ & $0.31 \%$ & $0.25 \%$ \\
\hline Italy & $12.39 \%$ & $8.51 \%$ & $7.94 \%$ & $3.83 \%$ & $5.45 \%$ & $9.72 \%$ & $7.85 \%$ & $11.71 \%$ & $10.78 \%$ & $8.69 \%$ \\
\hline Japan & $39.03 \%$ & $26.80 \%$ & $25.03 \%$ & $12.08 \%$ & $17.18 \%$ & $30.62 \%$ & $24.75 \%$ & $36.89 \%$ & $33.95 \%$ & $27.37 \%$ \\
\hline Luxembourg & $0.02 \%$ & $0.01 \%$ & $0.01 \%$ & $0.00 \%$ & $0.01 \%$ & $0.01 \%$ & $0.01 \%$ & $0.01 \%$ & $0.01 \%$ & $0.01 \%$ \\
\hline Malaysia & $1.83 \%$ & $1.25 \%$ & $1.17 \%$ & $0.57 \%$ & $0.80 \%$ & $1.43 \%$ & $1.16 \%$ & $1.73 \%$ & $1.59 \%$ & $1.28 \%$ \\
\hline Mexico & $11.46 \%$ & $7.87 \%$ & $7.35 \%$ & $3.55 \%$ & $5.04 \%$ & $8.99 \%$ & $7.26 \%$ & $10.83 \%$ & $9.97 \%$ & $8.03 \%$ \\
\hline Netherlands & $11.89 \%$ & $8.16 \%$ & $7.62 \%$ & $3.68 \%$ & $5.23 \%$ & $9.33 \%$ & $7.54 \%$ & $11.23 \%$ & $10.34 \%$ & $8.34 \%$ \\
\hline $\begin{array}{l}\text { New } \\
\text { Zealand }\end{array}$ & $0.01 \%$ & $0.00 \%$ & $0.00 \%$ & $0.00 \%$ & $0.00 \%$ & $0.00 \%$ & $0.00 \%$ & $0.00 \%$ & $0.00 \%$ & $0.00 \%$ \\
\hline Norway & $2.84 \%$ & $1.95 \%$ & $1.82 \%$ & $0.88 \%$ & $1.25 \%$ & $2.23 \%$ & $1.80 \%$ & $2.69 \%$ & $2.47 \%$ & $1.99 \%$ \\
\hline Portugal & $0.35 \%$ & $0.24 \%$ & $0.22 \%$ & $0.11 \%$ & $0.15 \%$ & $0.27 \%$ & $0.22 \%$ & $0.33 \%$ & $0.30 \%$ & $0.24 \%$ \\
\hline Russia & $22.37 \%$ & $15.36 \%$ & $14.34 \%$ & $6.92 \%$ & $9.84 \%$ & $17.55 \%$ & $14.18 \%$ & $21.14 \%$ & $19.46 \%$ & $15.69 \%$ \\
\hline Slovakia & $0.01 \%$ & $0.00 \%$ & $0.00 \%$ & $0.00 \%$ & $0.00 \%$ & $0.00 \%$ & $0.00 \%$ & $0.01 \%$ & $0.00 \%$ & $0.00 \%$ \\
\hline South Africa & $0.02 \%$ & $0.01 \%$ & $0.01 \%$ & $0.00 \%$ & $0.01 \%$ & $0.01 \%$ & $0.01 \%$ & $0.01 \%$ & $0.01 \%$ & $0.01 \%$ \\
\hline Spain & $33.47 \%$ & $22.98 \%$ & $21.46 \%$ & $10.36 \%$ & $14.73 \%$ & $26.26 \%$ & $21.22 \%$ & $31.63 \%$ & $29.11 \%$ & $23.47 \%$ \\
\hline Sweden & $3.36 \%$ & $2.31 \%$ & $2.16 \%$ & $1.04 \%$ & $1.48 \%$ & $2.64 \%$ & $2.13 \%$ & $3.18 \%$ & $2.93 \%$ & $2.36 \%$ \\
\hline Switzerland & $136.18 \%$ & $93.51 \%$ & $87.32 \%$ & $42.15 \%$ & $59.92 \%$ & $106.84 \%$ & $86.33 \%$ & $128.70 \%$ & $118.45 \%$ & $95.49 \%$ \\
\hline Turkey & $0.12 \%$ & $0.08 \%$ & $0.08 \%$ & $0.04 \%$ & $0.05 \%$ & $0.10 \%$ & $0.08 \%$ & $0.12 \%$ & $0.11 \%$ & $0.09 \%$ \\
\hline $\begin{array}{l}\text { United } \\
\text { Kingdom }\end{array}$ & $220.80 \%$ & $151.61 \%$ & $141.58 \%$ & $68.34 \%$ & $97.15 \%$ & $173.22 \%$ & $139.98 \%$ & $208.67 \%$ & $192.06 \%$ & $154.82 \%$ \\
\hline $\begin{array}{l}\text { Factor } \\
\text { Average }\end{array}$ & $28.47 \%$ & $19.55 \%$ & $18.25 \%$ & $8.81 \%$ & $12.53 \%$ & $22.34 \%$ & $18.05 \%$ & $26.91 \%$ & $24.76 \%$ & \\
\hline
\end{tabular}

\section{Appendix E. Global CoCo bond sellers' YTM_SCORE preference scores with incremental factor change}

The following tables present the incremental change in CoCo bond's global preference scores based on the 25th, 50th and 75th percentile benchmarks of YTM_SCORE in Panel A ( $\triangle$ YTM_SCORE_25), B ( $\Delta$ YTM_SCORE_50) and C ( $\Delta$ YTM_SCORE_75), respectively. We provide the global preference scores with the incremental changes in significant factors in Table 3 and 4 . The preference scores are scaled by the market power score for each country to provide country specific preference scores as in our equation (8) and (9). We report the country and factor average preference responses which are the average values across each row and column, respectively.

\begin{tabular}{llllll}
\hline \multicolumn{2}{l}{ Panel A. Sellers' $\Delta$ YTM_SCORE_25 } & & & \\
\hline Australia & CPN & CPN $\times$ CON & CPN $\times$ CRD & CON & Country Average \\
\hline Austria & $3.47 \%$ & $3.77 \%$ & $3.45 \%$ & $3.95 \%$ & $3.66 \%$ \\
Belgium & $3.16 \%$ & $3.43 \%$ & $3.14 \%$ & $3.59 \%$ & $3.33 \%$ \\
Brazil & $2.44 \%$ & $2.65 \%$ & $2.42 \%$ & $2.77 \%$ & $2.57 \%$ \\
China & $43.26 \%$ & $46.97 \%$ & $42.95 \%$ & $49.16 \%$ & $45.58 \%$ \\
Colombia & $997.37 \%$ & $1083.00 \%$ & $990.32 \%$ & $1133.46 \%$ & $1051.04 \%$ \\
Croatia & $0.28 \%$ & $0.31 \%$ & $0.28 \%$ & $0.32 \%$ & $0.30 \%$ \\
& $0.01 \%$ & $0.01 \%$ & $0.00 \%$ & $0.01 \%$ & $0.01 \%$
\end{tabular}

(continued on next page) 
Global CoCo bond sellers' YTM_SCORE preference scores with incremental factor change (continued)

\begin{tabular}{|c|c|c|c|c|c|}
\hline \multicolumn{6}{|c|}{ Panel A. Sellers' $\Delta$ YTM_SCORE_25 } \\
\hline & $\mathrm{CPN}$ & $\mathrm{CPN} \times \mathrm{CON}$ & $\mathrm{CPN} \times \mathrm{CRD}$ & $\mathrm{CON}$ & Country Average \\
\hline Cyprus & $0.19 \%$ & $0.21 \%$ & $0.19 \%$ & $0.22 \%$ & $0.20 \%$ \\
\hline Czech & $0.04 \%$ & $0.04 \%$ & $0.04 \%$ & $0.04 \%$ & $0.04 \%$ \\
\hline Denmark & $6.67 \%$ & $7.24 \%$ & $6.62 \%$ & $7.58 \%$ & $7.03 \%$ \\
\hline Estonia & $0.00 \%$ & $0.00 \%$ & $0.00 \%$ & $0.00 \%$ & $0.00 \%$ \\
\hline Finland & $7.47 \%$ & $8.11 \%$ & $7.41 \%$ & $8.49 \%$ & $7.87 \%$ \\
\hline France & $225.79 \%$ & $245.18 \%$ & $224.20 \%$ & $256.60 \%$ & $237.94 \%$ \\
\hline Georgia & $0.12 \%$ & $0.12 \%$ & $0.11 \%$ & $0.13 \%$ & $0.12 \%$ \\
\hline Germany & $12.21 \%$ & $13.26 \%$ & $12.13 \%$ & $13.88 \%$ & $12.87 \%$ \\
\hline Hungary & $0.01 \%$ & $0.01 \%$ & $0.01 \%$ & $0.01 \%$ & $0.01 \%$ \\
\hline India & $6.48 \%$ & $7.04 \%$ & $6.43 \%$ & $7.36 \%$ & $6.83 \%$ \\
\hline Indonesia & $0.00 \%$ & $0.00 \%$ & $0.00 \%$ & $0.00 \%$ & $0.00 \%$ \\
\hline Ireland & $1.42 \%$ & $1.54 \%$ & $1.41 \%$ & $1.61 \%$ & $1.50 \%$ \\
\hline Israel & $0.84 \%$ & $0.91 \%$ & $0.84 \%$ & $0.96 \%$ & $0.89 \%$ \\
\hline Italy & $29.15 \%$ & $31.65 \%$ & $28.94 \%$ & $33.13 \%$ & $30.72 \%$ \\
\hline Japan & $91.85 \%$ & $99.73 \%$ & $91.20 \%$ & $104.38 \%$ & $96.79 \%$ \\
\hline Luxembourg & $0.04 \%$ & $0.04 \%$ & $0.04 \%$ & $0.04 \%$ & $0.04 \%$ \\
\hline Malaysia & $4.30 \%$ & $4.67 \%$ & $4.27 \%$ & $4.89 \%$ & $4.53 \%$ \\
\hline Mexico & $26.96 \%$ & $29.27 \%$ & $26.77 \%$ & $30.64 \%$ & $28.41 \%$ \\
\hline Netherlands & $27.97 \%$ & $30.37 \%$ & $27.77 \%$ & $31.79 \%$ & $29.48 \%$ \\
\hline New Zealand & $0.01 \%$ & $0.01 \%$ & $0.01 \%$ & $0.01 \%$ & $0.01 \%$ \\
\hline Norway & $6.69 \%$ & $7.26 \%$ & $6.64 \%$ & $7.60 \%$ & $7.05 \%$ \\
\hline Portugal & $0.82 \%$ & $0.89 \%$ & $0.81 \%$ & $0.93 \%$ & $0.86 \%$ \\
\hline Russia & $52.64 \%$ & $57.16 \%$ & $52.27 \%$ & $59.82 \%$ & $55.47 \%$ \\
\hline Slovakia & $0.01 \%$ & $0.01 \%$ & $0.01 \%$ & $0.01 \%$ & $0.01 \%$ \\
\hline South Africa & $0.04 \%$ & $0.04 \%$ & $0.04 \%$ & $0.04 \%$ & $0.04 \%$ \\
\hline Spain & $78.75 \%$ & $85.52 \%$ & $78.20 \%$ & $89.50 \%$ & $82.99 \%$ \\
\hline Sweden & $7.91 \%$ & $8.59 \%$ & $7.86 \%$ & $8.99 \%$ & $8.34 \%$ \\
\hline Switzerland & $320.43 \%$ & $347.95 \%$ & $318.17 \%$ & $364.16 \%$ & $337.68 \%$ \\
\hline Turkey & $0.29 \%$ & $0.31 \%$ & $0.29 \%$ & $0.33 \%$ & $0.30 \%$ \\
\hline United Kingdom & $519.54 \%$ & $564.15 \%$ & $515.87 \%$ & $590.44 \%$ & $547.50 \%$ \\
\hline FactorAverage & $66.99 \%$ & $72.74 \%$ & $66.52 \%$ & $76.13 \%$ & \\
\hline
\end{tabular}

\begin{tabular}{|c|c|c|c|c|c|}
\hline \multicolumn{6}{|c|}{ Panel B. Sellers' $\Delta$ YTM_SCORE_50 } \\
\hline & $\mathrm{CPN}$ & $\mathrm{CPN} \times \mathrm{CRD}$ & TRI & MAT & Country Average \\
\hline Australia & $1.30 \%$ & $1.10 \%$ & $0.60 \%$ & $4.56 \%$ & $1.89 \%$ \\
\hline Austria & $1.18 \%$ & $1.00 \%$ & $0.54 \%$ & $4.15 \%$ & $1.72 \%$ \\
\hline Belgium & $0.91 \%$ & $0.77 \%$ & $0.42 \%$ & $3.20 \%$ & $1.32 \%$ \\
\hline Brazil & $16.15 \%$ & $13.65 \%$ & $7.45 \%$ & $56.80 \%$ & $23.51 \%$ \\
\hline China & $372.40 \%$ & $314.66 \%$ & $171.81 \%$ & $1309.71 \%$ & $542.14 \%$ \\
\hline Colombia & $0.11 \%$ & $0.09 \%$ & $0.05 \%$ & $0.37 \%$ & $0.15 \%$ \\
\hline Croatia & $0.00 \%$ & $0.00 \%$ & $0.00 \%$ & $0.01 \%$ & $0.00 \%$ \\
\hline Cyprus & $0.07 \%$ & $0.06 \%$ & $0.03 \%$ & $0.25 \%$ & $0.10 \%$ \\
\hline Czech & $0.01 \%$ & $0.01 \%$ & $0.01 \%$ & $0.05 \%$ & $0.02 \%$ \\
\hline Denmark & $2.49 \%$ & $2.10 \%$ & $1.15 \%$ & $8.76 \%$ & $3.63 \%$ \\
\hline Estonia & $0.00 \%$ & $0.00 \%$ & $0.00 \%$ & $0.00 \%$ & $0.00 \%$ \\
\hline Finland & $2.79 \%$ & $2.36 \%$ & $1.29 \%$ & $9.80 \%$ & $4.06 \%$ \\
\hline France & $84.31 \%$ & $71.23 \%$ & $38.90 \%$ & $296.50 \%$ & $122.73 \%$ \\
\hline Georgia & $0.04 \%$ & $0.04 \%$ & $0.02 \%$ & $0.15 \%$ & $0.06 \%$ \\
\hline Germany & $4.56 \%$ & $3.85 \%$ & $2.10 \%$ & $16.04 \%$ & $6.64 \%$ \\
\hline Hungary & $0.00 \%$ & $0.00 \%$ & $0.00 \%$ & $0.02 \%$ & $0.01 \%$ \\
\hline India & $2.42 \%$ & $2.04 \%$ & $1.12 \%$ & $8.51 \%$ & $3.52 \%$ \\
\hline
\end{tabular}


Global CoCo bond sellers' YTM_SCORE preference scores with incremental factor change (continued)

\begin{tabular}{|c|c|c|c|c|c|}
\hline \multicolumn{6}{|c|}{ Panel B. Sellers' $\triangle$ YTM_SCORE_50 } \\
\hline & CPN & $\mathrm{CPN} \times \mathrm{CRD}$ & TRI & MAT & Country Average \\
\hline Indonesia & $0.00 \%$ & $0.00 \%$ & $0.00 \%$ & $0.00 \%$ & $0.00 \%$ \\
\hline Ireland & $0.53 \%$ & $0.45 \%$ & $0.24 \%$ & $1.87 \%$ & $0.77 \%$ \\
\hline Israel & $0.31 \%$ & $0.27 \%$ & $0.15 \%$ & $1.11 \%$ & $0.46 \%$ \\
\hline Italy & $10.88 \%$ & $9.20 \%$ & $5.02 \%$ & $38.28 \%$ & $15.85 \%$ \\
\hline Japan & $34.29 \%$ & $28.98 \%$ & $15.82 \%$ & $120.61 \%$ & $49.93 \%$ \\
\hline Luxembourg & $0.01 \%$ & $0.01 \%$ & $0.01 \%$ & $0.05 \%$ & $0.02 \%$ \\
\hline Malaysia & $1.61 \%$ & $1.36 \%$ & $0.74 \%$ & $5.65 \%$ & $2.34 \%$ \\
\hline Mexico & $10.07 \%$ & $8.51 \%$ & $4.64 \%$ & $35.40 \%$ & $14.65 \%$ \\
\hline Netherlands & $10.44 \%$ & $8.82 \%$ & $4.82 \%$ & $36.73 \%$ & $15.20 \%$ \\
\hline New Zealand & $0.00 \%$ & $0.00 \%$ & $0.00 \%$ & $0.02 \%$ & $0.01 \%$ \\
\hline Norway & $2.50 \%$ & $2.11 \%$ & $1.15 \%$ & $8.78 \%$ & $3.64 \%$ \\
\hline Portugal & $0.30 \%$ & $0.26 \%$ & $0.14 \%$ & $1.07 \%$ & $0.44 \%$ \\
\hline Russia & $19.65 \%$ & $16.61 \%$ & $9.07 \%$ & $69.12 \%$ & $28.61 \%$ \\
\hline Slovakia & $0.00 \%$ & $0.00 \%$ & $0.00 \%$ & $0.02 \%$ & $0.01 \%$ \\
\hline South Africa & $0.01 \%$ & $0.01 \%$ & $0.01 \%$ & $0.05 \%$ & $0.02 \%$ \\
\hline Spain & $29.41 \%$ & $24.85 \%$ & $13.57 \%$ & $103.42 \%$ & $42.81 \%$ \\
\hline Sweden & $2.95 \%$ & $2.50 \%$ & $1.36 \%$ & $10.39 \%$ & $4.30 \%$ \\
\hline Switzerland & $119.64 \%$ & $101.09 \%$ & $55.20 \%$ & $420.78 \%$ & $174.18 \%$ \\
\hline Turkey & $0.11 \%$ & $0.09 \%$ & $0.05 \%$ & $0.38 \%$ & $0.16 \%$ \\
\hline United Kingdom & $193.99 \%$ & $163.91 \%$ & $89.50 \%$ & $682.25 \%$ & $282.41 \%$ \\
\hline FactorAverage & $25.01 \%$ & $21.13 \%$ & $11.54 \%$ & $87.97 \%$ & \\
\hline
\end{tabular}




\begin{tabular}{|c|c|c|c|c|c|c|c|c|c|c|c|c|c|c|}
\hline \multicolumn{15}{|c|}{ Panel C. Sellers' $\Delta$ YTM_SCORE_75 } \\
\hline & CPN & $\mathrm{CPN} \times \mathrm{CRD}$ & TRI & $\mathrm{CON}$ & CRD & MAT & AMT & $\mathrm{AMT} \times \mathrm{ROE}$ & CDS & $\mathrm{P} / \mathrm{B}$ & SIZE & $\begin{array}{l}\text { TRC/ } \\
\text { RWA }\end{array}$ & CPI & $\begin{array}{l}\text { Country } \\
\text { Average }\end{array}$ \\
\hline Australia & $1.53 \%$ & $1.00 \%$ & $0.89 \%$ & $0.43 \%$ & $1.38 \%$ & $0.00 \%$ & $0.67 \%$ & $1.16 \%$ & $0.96 \%$ & $1.31 \%$ & $1.25 \%$ & $1.28 \%$ & $0.86 \%$ & $0.98 \%$ \\
\hline Austria & $1.39 \%$ & $0.91 \%$ & $0.81 \%$ & $0.39 \%$ & $1.25 \%$ & $0.00 \%$ & $0.61 \%$ & $1.05 \%$ & $0.88 \%$ & $1.19 \%$ & $1.14 \%$ & $1.17 \%$ & $0.78 \%$ & $0.89 \%$ \\
\hline Belgium & $1.07 \%$ & $0.70 \%$ & $0.62 \%$ & $0.30 \%$ & $0.96 \%$ & $0.00 \%$ & $0.47 \%$ & $0.81 \%$ & $0.68 \%$ & $0.92 \%$ & $0.88 \%$ & $0.90 \%$ & $0.60 \%$ & $0.69 \%$ \\
\hline Brazil & $19.08 \%$ & $12.48 \%$ & $11.07 \%$ & $5.36 \%$ & $17.13 \%$ & $0.00 \%$ & $8.37 \%$ & $14.41 \%$ & $12.00 \%$ & $16.31 \%$ & $15.55 \%$ & $15.95 \%$ & $10.67 \%$ & $12.18 \%$ \\
\hline China & $439.88 \%$ & $287.79 \%$ & $255.29 \%$ & $123.56 \%$ & $394.91 \%$ & $0.03 \%$ & $192.96 \%$ & $332.30 \%$ & $276.78 \%$ & $376.05 \%$ & $358.53 \%$ & $367.78 \%$ & $246.04 \%$ & $280.92 \%$ \\
\hline Colombia & $0.12 \%$ & $0.08 \%$ & $0.07 \%$ & $0.03 \%$ & $0.11 \%$ & $0.00 \%$ & $0.05 \%$ & $0.09 \%$ & $0.08 \%$ & $0.11 \%$ & $0.10 \%$ & $0.10 \%$ & $0.07 \%$ & $0.08 \%$ \\
\hline Croatia & $0.00 \%$ & $0.00 \%$ & $0.00 \%$ & $0.00 \%$ & $0.00 \%$ & $0.00 \%$ & $0.00 \%$ & $0.00 \%$ & $0.00 \%$ & $0.00 \%$ & $0.00 \%$ & $0.00 \%$ & $0.00 \%$ & $0.00 \%$ \\
\hline Cyprus & $0.08 \%$ & $0.06 \%$ & $0.05 \%$ & $0.02 \%$ & $0.08 \%$ & $0.00 \%$ & $0.04 \%$ & $0.06 \%$ & $0.05 \%$ & $0.07 \%$ & $0.07 \%$ & $0.07 \%$ & $0.05 \%$ & $0.05 \%$ \\
\hline Czech & $0.02 \%$ & $0.01 \%$ & $0.01 \%$ & $0.00 \%$ & $0.01 \%$ & $0.00 \%$ & $0.01 \%$ & $0.01 \%$ & $0.01 \%$ & $0.01 \%$ & $0.01 \%$ & $0.01 \%$ & $0.01 \%$ & $0.01 \%$ \\
\hline Denmark & $2.94 \%$ & $1.92 \%$ & $1.71 \%$ & $0.83 \%$ & $2.64 \%$ & $0.00 \%$ & $1.29 \%$ & $2.22 \%$ & $1.85 \%$ & $2.51 \%$ & $2.40 \%$ & $2.46 \%$ & $1.65 \%$ & $1.88 \%$ \\
\hline Estonia & $0.00 \%$ & $0.00 \%$ & $0.00 \%$ & $0.00 \%$ & $0.00 \%$ & $0.00 \%$ & $0.00 \%$ & $0.00 \%$ & $0.00 \%$ & $0.00 \%$ & $0.00 \%$ & $0.00 \%$ & $0.00 \%$ & $0.00 \%$ \\
\hline Finland & $3.29 \%$ & $2.15 \%$ & $1.91 \%$ & $0.92 \%$ & $2.96 \%$ & $0.00 \%$ & $1.44 \%$ & $2.49 \%$ & $2.07 \%$ & $2.82 \%$ & $2.68 \%$ & $2.75 \%$ & $1.84 \%$ & $2.10 \%$ \\
\hline France & $99.58 \%$ & $65.15 \%$ & $57.79 \%$ & $27.97 \%$ & $89.40 \%$ & $0.01 \%$ & $43.68 \%$ & $75.23 \%$ & $62.66 \%$ & $85.13 \%$ & $81.17 \%$ & $83.26 \%$ & $55.70 \%$ & $63.60 \%$ \\
\hline Georgia & $0.05 \%$ & $0.03 \%$ & $0.03 \%$ & $0.01 \%$ & $0.05 \%$ & $0.00 \%$ & $0.02 \%$ & $0.04 \%$ & $0.03 \%$ & $0.04 \%$ & $0.04 \%$ & $0.04 \%$ & $0.03 \%$ & $0.03 \%$ \\
\hline Germany & $5.39 \%$ & $3.52 \%$ & $3.13 \%$ & $1.51 \%$ & $4.84 \%$ & $0.00 \%$ & $2.36 \%$ & $4.07 \%$ & $3.39 \%$ & $4.61 \%$ & $4.39 \%$ & $4.50 \%$ & $3.01 \%$ & $3.44 \%$ \\
\hline Hungary & $0.01 \%$ & $0.00 \%$ & $0.00 \%$ & $0.00 \%$ & $0.00 \%$ & $0.00 \%$ & $0.00 \%$ & $0.00 \%$ & $0.00 \%$ & $0.00 \%$ & $0.00 \%$ & $0.00 \%$ & $0.00 \%$ & $0.00 \%$ \\
\hline India & $2.86 \%$ & $1.87 \%$ & $1.66 \%$ & $0.80 \%$ & $2.57 \%$ & $0.00 \%$ & $1.25 \%$ & $2.16 \%$ & $1.80 \%$ & $2.44 \%$ & $2.33 \%$ & $2.39 \%$ & $1.60 \%$ & $1.83 \%$ \\
\hline Indonesia & $0.00 \%$ & $0.00 \%$ & $0.00 \%$ & $0.00 \%$ & $0.00 \%$ & $0.00 \%$ & $0.00 \%$ & $0.00 \%$ & $0.00 \%$ & $0.00 \%$ & $0.00 \%$ & $0.00 \%$ & $0.00 \%$ & $0.00 \%$ \\
\hline Ireland & $0.63 \%$ & $0.41 \%$ & $0.36 \%$ & $0.18 \%$ & $0.56 \%$ & $0.00 \%$ & $0.27 \%$ & $0.47 \%$ & $0.39 \%$ & $0.54 \%$ & $0.51 \%$ & $0.52 \%$ & $0.35 \%$ & $0.40 \%$ \\
\hline Israel & $0.37 \%$ & $0.24 \%$ & $0.22 \%$ & $0.10 \%$ & $0.33 \%$ & $0.00 \%$ & $0.16 \%$ & $0.28 \%$ & $0.23 \%$ & $0.32 \%$ & $0.30 \%$ & $0.31 \%$ & $0.21 \%$ & $0.24 \%$ \\
\hline Italy & $12.86 \%$ & $8.41 \%$ & $7.46 \%$ & $3.61 \%$ & $11.54 \%$ & $0.00 \%$ & $5.64 \%$ & $9.71 \%$ & $8.09 \%$ & $10.99 \%$ & $10.48 \%$ & $10.75 \%$ & $7.19 \%$ & $8.21 \%$ \\
\hline Japan & $40.51 \%$ & $26.50 \%$ & $23.51 \%$ & $11.38 \%$ & $36.37 \%$ & $0.00 \%$ & $17.77 \%$ & $30.60 \%$ & $25.49 \%$ & $34.63 \%$ & $33.02 \%$ & $33.87 \%$ & $22.66 \%$ & $25.87 \%$ \\
\hline Luxembourg & $0.02 \%$ & $0.01 \%$ & $0.01 \%$ & $0.00 \%$ & $0.01 \%$ & $0.00 \%$ & $0.01 \%$ & $0.01 \%$ & $0.01 \%$ & $0.01 \%$ & $0.01 \%$ & $0.01 \%$ & $0.01 \%$ & $0.01 \%$ \\
\hline Malaysia & $1.90 \%$ & $1.24 \%$ & $1.10 \%$ & $0.53 \%$ & $1.70 \%$ & $0.00 \%$ & $0.83 \%$ & $1.43 \%$ & $1.19 \%$ & $1.62 \%$ & $1.55 \%$ & $1.59 \%$ & $1.06 \%$ & $1.21 \%$ \\
\hline Mexico & $11.89 \%$ & $7.78 \%$ & $6.90 \%$ & $3.34 \%$ & $10.67 \%$ & $0.00 \%$ & $5.22 \%$ & $8.98 \%$ & $7.48 \%$ & $10.16 \%$ & $9.69 \%$ & $9.94 \%$ & $6.65 \%$ & $7.59 \%$ \\
\hline Netherlands & $12.34 \%$ & $8.07 \%$ & $7.16 \%$ & $3.47 \%$ & $11.08 \%$ & $0.00 \%$ & $5.41 \%$ & $9.32 \%$ & $7.76 \%$ & $10.55 \%$ & $10.05 \%$ & $10.31 \%$ & $6.90 \%$ & $7.88 \%$ \\
\hline $\begin{array}{l}\text { New } \\
\text { Zealand }\end{array}$ & $0.01 \%$ & $0.00 \%$ & $0.00 \%$ & $0.00 \%$ & $0.00 \%$ & $0.00 \%$ & $0.00 \%$ & $0.00 \%$ & $0.00 \%$ & $0.00 \%$ & $0.00 \%$ & $0.00 \%$ & $0.00 \%$ & $0.00 \%$ \\
\hline Norway & $2.95 \%$ & $1.93 \%$ & $1.71 \%$ & $0.83 \%$ & $2.65 \%$ & $0.00 \%$ & $1.29 \%$ & $2.23 \%$ & $1.86 \%$ & $2.52 \%$ & $2.40 \%$ & $2.47 \%$ & $1.65 \%$ & $1.88 \%$ \\
\hline Portugal & $0.36 \%$ & $0.24 \%$ & $0.21 \%$ & $0.10 \%$ & $0.32 \%$ & $0.00 \%$ & $0.16 \%$ & $0.27 \%$ & $0.23 \%$ & $0.31 \%$ & $0.29 \%$ & $0.30 \%$ & $0.20 \%$ & $0.23 \%$ \\
\hline Russia & $23.22 \%$ & $15.19 \%$ & $13.47 \%$ & $6.52 \%$ & $20.84 \%$ & $0.00 \%$ & $10.18 \%$ & $17.54 \%$ & $14.61 \%$ & $19.85 \%$ & $18.92 \%$ & $19.41 \%$ & $12.99 \%$ & $14.83 \%$ \\
\hline Slovakia & $0.01 \%$ & $0.00 \%$ & $0.00 \%$ & $0.00 \%$ & $0.01 \%$ & $0.00 \%$ & $0.00 \%$ & $0.00 \%$ & $0.00 \%$ & $0.00 \%$ & $0.00 \%$ & $0.00 \%$ & $0.00 \%$ & $0.00 \%$ \\
\hline South Africa & $0.02 \%$ & $0.01 \%$ & $0.01 \%$ & $0.00 \%$ & $0.01 \%$ & $0.00 \%$ & $0.01 \%$ & $0.01 \%$ & $0.01 \%$ & $0.01 \%$ & $0.01 \%$ & $0.01 \%$ & $0.01 \%$ & $0.01 \%$ \\
\hline Spain & $34.73 \%$ & $22.72 \%$ & $20.16 \%$ & $9.76 \%$ & $31.18 \%$ & $0.00 \%$ & $15.24 \%$ & $26.24 \%$ & $21.86 \%$ & $29.69 \%$ & $28.31 \%$ & $29.04 \%$ & $19.43 \%$ & $22.18 \%$ \\
\hline Sweden & $3.49 \%$ & $2.28 \%$ & $2.03 \%$ & $0.98 \%$ & $3.13 \%$ & $0.00 \%$ & $1.53 \%$ & $2.64 \%$ & $2.20 \%$ & $2.98 \%$ & $2.84 \%$ & $2.92 \%$ & $1.95 \%$ & $2.23 \%$ \\
\hline Switzerland & $141.33 \%$ & $92.46 \%$ & $82.02 \%$ & $39.70 \%$ & $126.88 \%$ & $0.01 \%$ & $62.00 \%$ & $106.76 \%$ & $88.92 \%$ & $120.82 \%$ & $115.19 \%$ & $118.16 \%$ & $79.05 \%$ & $90.25 \%$ \\
\hline Turkey & $0.13 \%$ & $0.08 \%$ & $0.07 \%$ & $0.04 \%$ & $0.11 \%$ & $0.00 \%$ & $0.06 \%$ & $0.10 \%$ & $0.08 \%$ & $0.11 \%$ & $0.10 \%$ & $0.11 \%$ & $0.07 \%$ & $0.08 \%$ \\
\hline $\begin{array}{l}\text { United } \\
\text { Kingdom }\end{array}$ & $229.14 \%$ & $149.91 \%$ & $132.98 \%$ & $64.36 \%$ & $205.72 \%$ & $0.01 \%$ & $100.52 \%$ & $173.10 \%$ & $144.18 \%$ & $195.89 \%$ & $186.76 \%$ & $191.58 \%$ & $128.17 \%$ & $146.33 \%$ \\
\hline $\begin{array}{l}\text { Factor } \\
\text { Average }\end{array}$ & $29.55 \%$ & $19.33 \%$ & $17.15 \%$ & $8.30 \%$ & $26.53 \%$ & $0.00 \%$ & $12.96 \%$ & $22.32 \%$ & $18.59 \%$ & $25.26 \%$ & $24.08 \%$ & $24.70 \%$ & $16.53 \%$ & \\
\hline
\end{tabular}




\section{Appendix F. Country average response of the CoCo bond's preference score}

The following figure shows the country average preference responses for CoCo bond buyers global $\triangle \mathrm{YTC}$ _SCORE. We take the average of our 25th, 50th, 75th percentiles preference scores for each country in Appendix B. We show the buyers global $\triangle$ YTC_SCORE as a representative one while the overall map results are highly similar to the sellers' one. The darker shades indicate larger absolute values of the country average preference response.

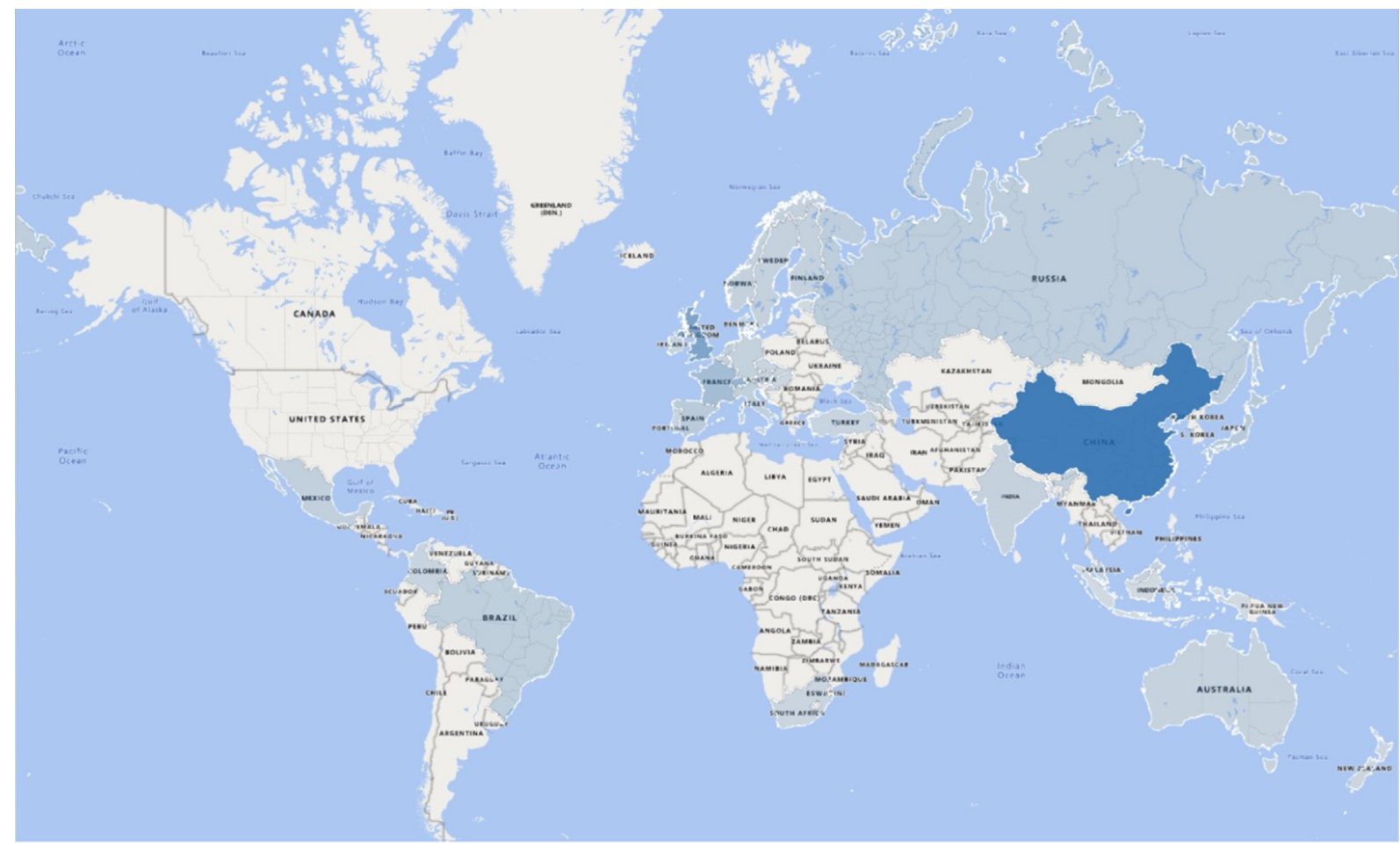

\section{References}

Admati, A.R., DeMarzo, P.M., Hellwig, M.F., Pfleiderer, P.C., 2013. Fallacies, Irrelevant Facts, and Myths in the Discussion of Capital Regulation: Why Bank Equity is Not Socially Expensive [Research Paper 13-7], Stanford University Graduate School of Business.

Albul, B., Jaffee, D.M., Tchistyi, A., 2013. Contingent capital debt and capital structure decisions [Working paper]. Hass School of Business, UC Berkeley.

Ammann, M., Blickle, K., Ehmann, C., 2017. Announcement Effects of contingent convertible securities: evidence from the global banking industry. Eur. Financial Manage. 23, 127-152.

Avdjiev, S., Kartasheva, A., Bogdanova, B., 2013. CoCos: A primer. BIS Quarterly Rev.

Avdjiev, S., Bolton, P., Jiang, W., Kartasheva, A., Bogdanova, B., 2015. CoCo bond issuance and bank funding costs [Working paper]. BIS and Columbia University.

Ayache, E., Forsyth, P., Vetzal, K., 2003. Valuation of convertible bonds with credit risk. J. Derivatives 11 (1), 9-29.

Baily, M.N., Campbell, J.Y., Cochrane, J.H., Diamond, D.W., Duffie, D., French, K.R., Kashyap, A.K., Mishkin, F.S., Rajan, R., Scharfstein, D.S., Shiller, R.J., Slaughter, M.J., Shin, H.S., Stein, J., Stulz, R.M., 2013. Aligning incentives at systemically important financial institutions: a proposal by the Squam Lake Group. J. Appl. Corporate Finance 25 (4), 37-40.

Birchler, U.W., Facchinetti, M., 2007. Self-destroying prophecies? The endogeneity pitfall in using market signals as triggers for prompt corrective action [Task force paper]. BIS Res.

Bond, P., Goldstein, I., Prescott, E., 2010. Market-based corrective actions. Rev. Financial Stud. 23 (2), $781-820$.

Brennan, M., Schwartz, E., 1977. Convertible bonds: valuation and optimal strategies for call and conversion. J. Finance 32 (5), $1699-1715$.

Brennan, M., Schwartz, E., 1980. Analyzing convertible bonds. J. Financial Quant. Anal. 15 (4), $907-929$.

Calomiris, C.W., Herring, R.J., 2013. How to design a contingent convertible debt requirement that helps solve my too-big-to-fail problem. J. Appl. Corporate Finance 25 (2), 39-62.

Chen, N., Glasserman, P., Nouri, B., Pelger, M., 2013. CoCos, bail-in, and tail risk [Working paper \#0004], Office of Financial Research.

Corcuera, J.M., De Spiegeleer, J., Fajardo, J., Jönsson, H., Schoutens, W., Valdivia, A., 2014. Close form pricing formulas for coupon cancellable CoCos. J. Bank. Finance 42, 339-351.

Davis, D., Korenok, O., Prescott, E.S., 2014. An experimental analysis of contingent capital with market-price triggers. J. Money, Credit Banking 46 (5), 9991033.

Davis, D., Prescott, E., Korenok, O., 2011. Market-based corrective actions: An experimental investigation [Working paper 11-01], Federal Reserve Bank of Richmond.

De Spiegeleer, J., Schoutens, W., Van Hulle, C., 2014. The Handbook of Hybrid Securities. Convertible bonds, CoCo bonds, and bail-in. John Wiley \& Sons Ltd. 
Flannery, M.J., 2005. No pain, no gain? Effecting market discipline via “reverse convertible debentures. In: Scott, H.S. (Ed.), Capital Adequacy beyond Basel: Banking, Securities, and Insurance. Oxford University Press.

Flannery, M.J., 2016. Stabilizing large financial institutions with contingent capital certificates. Quart. J. Finance 06 (02), 1650006.

Geon, H., Hyun, J., Young, H., 2019. Pricing contingent convertible bonds: an analytical approach based on two-dimensional stochastic processes. Statistics Probability Lett. 148, 43-53.

Glasserman, P., Nouri, B., 2012. Contingent capital with a capital-ratio trigger. Manage. Sci. 58 (10), $1816-1833$.

Gründl, H., Niedrig, T., 2015. The effects of contingent convertible (CoCo) bonds on insurers' capital requirements under Solvency II. The Geneva Association's Insurance and Finance Newsletter.

Hesse, H., 2018. Incentive Effects from Write-down CoCo Bonds: An Empirical Analysis. SAFE Working Paper No. 212.

Himmelberg, C.P. and S. Tsyplakov, 2012, Pricing contingent capital bonds: Incentives matter [Working paper], University of South Carolina.

Hilscher, J., Raviv, A., 2014. Bank stability and market discipline: the effect of contingent capital on risk taking and default probability. J. Corporate Finance 29, 542-560.

Ho, T., Pfeffer, D., 1996. Convertible bonds: model, value attribution, and analytics. Financial Anal. J. 52 (5), $35-44$.

Ingersoll, J., 1977. A contingent-claims valuation of convertible securities. J. Financ. Econ. 4 (3), 289-321.

Jaworskia, P., Liberadzkib, K., Liberadzkib, M., 2017. How does issuing contingent convertible bonds improve bank's solvency? A value-at-risk and expected shortfall approach. Econ. Model. 60, 162-168.

Koziol, C., Lawrenz, J., 2012. Contingent convertibles. Solving or seeding the next banking crisis?'. J. Bank. Finance 36 (1), $90-104$.

Liao, Q., Mehdian, S., Rezvanian, R., 2017. An examination of investors' reaction to the announcement of CoCo bonds issuance: a global outlook. Finance Res. Lett. 22 (C), 58-65.

Martynova, N., Perotti, E., 2018. Convertible bond and bank risk-taking. J. Financial Intermedi. 35, issue PB, 61-80.

McDonald, R., 2013. Contingent capital with a dual price trigger. J. Financial Stability 9 (2), $230-241$.

Milanov, K., Kounchev, O., Fabozzi, F., 2019. A complete model for pricing coco bonds. J. Fixed Income 29 (3), $53-67$.

Pennacchi, G., 2010. A Structural Model of Contingent Bank Capital [Working Paper 10-04], Federal Reserve Bank of Cleveland.

Pennacchi, G., Vermaelen, T., Wolff, C.C.P., 2014. Contingent capital: The case for COERCS. J. Financial Quant. Anal. 49 (3), $541-574$.

Raviv, A., 2004. Bank stability and market discipline: Debt-for-equity swap versus subordinated notes [Working paper]. Hebrew University Business School. Song, D., Yang, Z., 2016. Contingent capital, real options, and agency costs. Int. Rev. Finance 16 (1), 3-40.

Squam Lake Working Group, 2009, An expedited resolution mechanism for distressed financial firms: Regulatory hybrid securities, Council on Foreign Relations.

Sundaresan, S., Wang, Z., 2015. On the design of contingent capital with a market trigger. J. Finance 70 (2), $881-920$.

Tsiveriotis, K., Fernandes, C., 1998. Valuing convertible bonds with credit risk. J. Fixed Income 8 (2), 95.

Vallée, B., 2016. Call me Maybe? The Effect of Exercising Contingent Capital [Working paper]. Harvard Business School.

Vallée, B., 2019, Contingent Capital Trigger Effects: Evidence from Liability Management Exercises. HEC Paris Research Paper No. FIN-2013-1014.

Yang, Z., Zhao, Z., 2015. Valuation and analysis of contingent convertible securities with jump risk. Int. Rev. Financial Anal. 41, 124-135.

Yang, Z., Zhao, Z., 2017. Contingent capital with repeated interconversion between debt and equity. Eur. Financial Manage. https://doi.org/10.1111/ eufm. 12165.

Zaevski, T., Kounchev, O., Savov, M., 2019. Two frameworks for pricing defaultable derivatives. Chaos, Solitons Fractals 123, 309-319. 